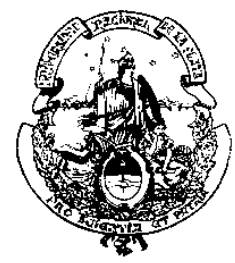

Maestría en Trabajo Social

Facultad de Trabajo Social

Universidad Nacional de La Plata

\title{
UN TRABAJADOR SOCIAL EN LA TOMA
}

Una etnografía sobre los sectores populares, los asentamientos urbanos y la intervención profesional

Maestrando: Luciano Raúl Lozano

Director: Dr. Jerónimo Pinedo.

Co-Director: Dr. Juan Ignacio Lozano

AÑ̃ 2020 


\section{INDICE}

Resumen................................................................................pp. 4

Resumo............................................................................pp. 4

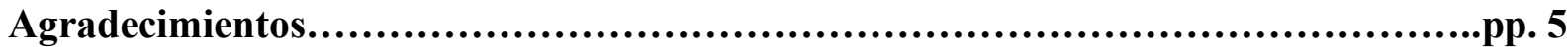

Introducción..................................................................pp. 7

\section{Capítulo 1:}

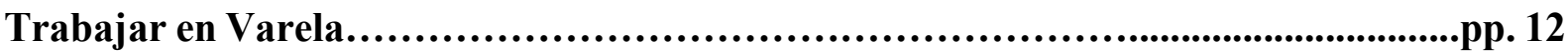

1. Mandatos y tentativas de un trabajador social en Florencio Varela.

2. Luciano, hablás como los piqueteros.

3. María la del barrio. Visitas, recorridos y aperturas del compromiso profesional.

4. De las reuniones de Red a Tania y los curas.

5. La risa de Tania y los asentamientos.

\section{Capítulo 2:}

¿Senderos que se bifurcan? Encrucijadas de un trabajador social como investigador. pp. 42

1. Senderos, encrucijadas y nuevas preguntas.

2. Etnografías sobre sectores populares y trabajo social: un encuentro posible.

\section{Capítulo 3.}

EI Trabajador social llega a la toma. La toma del 7 de

abril. pp. 53

1. La habilitación de Emilio.

2. La toma.

3. En la toma.

Capítulo 4. Formar un campamento indio entre promesas, fragmentación y la soledad del invierno. .pp. 66

1. En la vereda.

2. Formar un campamento indio entre promesas, fragmentación y la soledad del invierno.

3. El censo y el agravamiento de las diferencias entre Ariel y Emilio.

4. Vicisitudes y peripecias de la intervención profesional. 
Capítulo 5. Preparáte se te va a agrandar el barrio pp. 89

1. El Centro Mugica.

2. "Preparate Luciano vas a tener un área más grande".

Capítulo 6. Acompañar, seleccionar, organizar, mudar, tomar, hacer barrio.

1.“Si el Estado no garantiza donde podés vivir, qué querés que hagamos”. Los asentamientos 7 de abril y La cañada.

2. "Yo hago tipo Luciano".

3. "Saldivar era un cachivache": el desplazamiento de Emilio y de Leonor.

Capítulo 7. Entre el desgaste del municipio y el apriete del obispo. La consolidación de los nuevos barrios y el fin del Encuentro Territorial. pp. 108

1. El cansancio de Tania y las estrategias para obtener ayuda social.

2. El inicio del fin. El apriete del obispo y la ruptura del Encuentro Territorial.

Conclusión final pp. 120

Bibliografía pp. 126

Anexos pp. 135 


\section{RESUMEN}

En la presente tesis desarrollaré dos nudos temáticos relacionados entre sí: por un lado, el estudio de una toma de tierras, por otro, mi participación en ella como profesional empleado en una de las agencias del Estado municipal del área. Describiré mi participación en este proceso partiendo del análisis de las tareas desarrolladas en el marco de mi desempeño profesional. Voy a analizar cómo se fue conformando una red de colaboración con referentes y organizaciones barriales, donde la construcción de una agenda común de abordaje de problemáticas múltiples me fue insertando en la posibilidad de participar en la toma, y esa participación se transformó en el espacio mismo de mi análisis sobre el trabajo profesional, los sectores populares y los barrios surgidos de tomas de tierras.

En este recorrido dialogaré y debatiré con las dos grandes corrientes disciplinares que atravesaron mi formación de grado: la perspectiva "histórico crítica" y la "nacional y popular", cuyos aportes clarificado gran parte de mi trabajo pero no terminaron de responder los interrogantes que me fui formulando. Estas inquietudes me llevaron a buscar más allá de estas tradiciones teóricas y ensayar algunos vínculos entre la perspectiva etnográfica y la tarea profesional.

\section{RESUMO}

Nesta tese, desenvolverei dois nós cruciais e inter-relacionados: de um lado, o estudo da tomada de terra, de outro, minha participação nela como profissional empregado em um dos órgãos do governo municipal na área em que foi desenvolvida. Descreverei a minha participação neste processo com base na análise das tarefas desempenhadas no âmbito da minha atuação profissional. Vou analisar como se formou uma rede de colaboração com referentes e organizações de bairro, onde a construção de uma agenda comum para tratar de múltiplos problemas foi me inserindo na possibilidade de participar da tomada, e essa participação se transformou no próprio espaço da minha análise do trabalho profissional, setores populares e bairros que emergiram da grilagem de terras.

Nessa jornada, irei dialogar e debater com as duas grandes correntes disciplinares que perpassaram minha formação de graduação, a perspectiva "histórica crítica" e a perspectiva "nacional e popular", cujas contribuições esclareceram muito do meu trabalho, mas não terminaram de responder às questões que Eu estava me formulando. Essas preocupações me levaram a ir além dessas tradições teóricas e a tentar alguns vínculos entre a perspectiva etnográfica e a tarefa profissional. 


\section{Agradecimientos}

Esta tesis es resultado de mi trabajo en Florencio Varela y de mi paso por las Maestrías de Ciencias Sociales y de Trabajo Social de la UNLP. Sin embargo, jamás la hubiese escrito si no fuera por el apoyo y acompañamiento de numerosas personas.

En primer lugar, mi agradecimiento a Jerónimo Pinedo quien desde septiembre del año 2009 en el marco de la Maestría de Ciencias Sociales de la UNLP, comenzó siendo mi tutor y guiándome en este camino. A su paciencia, compromiso y capacidad profesional se debe en gran parte esta tesis.

Mi reconocimiento a la facultad de Trabajo Social de La Plata, a su Maestría y a la de Ciencias Sociales de la FAHCE.

A los protagonistas de esta tesis, cuyos nombres reales debí cambiar por diversas razones y fueron los que me enseñaron de qué se trataba eso que yo llamaba "la lucha por una sociedad mejor”: Tania, Camilo, Enrique, Mary, Pedro, Ariel, Mariano. Y a Emilio.

A todas las personas que atendí en la salita y a las que visité en las cárceles de la provincia. Aún hoy recuerdo sus temores, tristezas, alegrías e incertidumbre y sigo pensando si hice lo mejor que podía para aliviar un poco, al menos, las condiciones terribles en las que vivían.

A mi hermano Juan que transformó nuestras chicanas profesionales en elementos críticos para pensar esta tesis y me acompañó en cada detalle.

A Julieta Quirós quien en su visita a la salita en el 2007 y hasta el presente, me llevó a la etnografía y a empezar a entender la complejidad de ese mundo de Varela.

A José Scelsio cuyo acompañamiento en la facultad y en mis primeros pasos profesionales fueron fundamentales para mí.

A Virginia Manzano, Susana Cazzaniga y a Cristina Cravino, con quienes tuve la suerte de cursar.

Mi trabajo en Florencio Varela, con sus diferentes aristas no hubiese sido posible o no se hubiera dado de esta manera, sin la residencia PRIM. Mis colegas residentes en todos esos años, del 2007 al 2014, Valeria Contreras, Verónica Maldini, Lorena Ugarte, Amelia García, Pablo Sanhueza, Victoria De la Llosa, Gisele Fischer y Ana Inés Agostino, fueron fundamentales. Su entusiasmo, su mirada crítica, fomentada en gran parte por Lucila Fornetti su instructora, me impulsaron y permitieron profundizar estas líneas de trabajo, sintiéndome acompañado y contenido. Además conté con el aporte de profesionales de otras disciplinas que entendían que la salud trascendía el espacio de consultorio, como Viviana Sedran, Camila Minassian, Laura Espinosa, Mariana Tau, Nicolás Barbieri, Daniela Jalo, Mario Maugeri. 
A Sergio Raimundo, amigo, colega y compañero. A Stella Lugones la médica más comprometida que he conocido.

A Gisela Gómez, Soledad Tauler, amigas y colegas con quienes empezamos esa aventura de “ir a Varela" en las combis que salían del hospital San Martín en el 2005.

A mis colegas Claudia Muñoz de Toro, Victoria Pérez Avila, Carolina Andrada, Mirian Sosa, Mariana Debenedetti y Juan Di Meglio.

A los aportes de Mauricio Vidal, Melisa Campana, Tamara Oldani, Miguel Maiorana.

A mis compañeras y compañeros del Comité Contra la Tortura.

A mis compañeras del servicio social del Hospital de Área El Bolsón.

A Micaela Rende por sus correcciones y sugerencias en la escritura de la tesis.

A Marta Fernández, in memoriam, que recorría el barrio pegando afiches de la Red Contra la Violencia.

A Nicole, in memoriam, que luchó por tener un hogar.

A las integrantes de la Red Contra la Violencia del barrio Esmeralda.

Al equipo de la salita La Esmeralda que con mucha paciencia supieron alojarme tantos años.

A nivel personal, todo mi agradecimiento a Melina, mi compañera de vida, que año tras año, con su inconmensurable amor me impulsa a seguir creciendo como persona y profesional.

A mis viejos y hermanos, cuyo amor y sacrificio permitieron que pudiera estudiar. 


\section{INTRODUCCIÓN}

En la presente tesis desarrollaré dos nudos temáticos relacionados entre sí: por un lado, el estudio de una toma de tierras, por otro, mi participación en ella como profesional empleado en una de las agencias del Estado municipal del área donde se desarrolló dicho asentamiento. Describiré mi participación en este proceso partiendo del análisis de las tareas desarrolladas en el marco de mi desempeño como trabajador social. Voy a describir y analizar cómo se fue conformando una red de colaboración con referentes y organizaciones barriales, donde la construcción de una agenda común de abordaje de problemáticas múltiples emergentes de las propias condiciones del asentamiento, me fue insertando en la posibilidad de participar en la toma, y esa participación se transformó en el espacio mismo de mi análisis sobre el trabajo profesional, los sectores populares y los barrios surgidos de asentamientos o tomas de tierras en el Gran Buenos Aires.

En mi formación disciplinar de grado, según la apreciación de mi propia experiencia, dispuse de dos grandes corrientes teóricas políticas y metodológicas, claramente demarcadas. Las mismas produjeron abundante material sobre el compromiso profesional con la lucha de las clases populares. Mi recorrido en el proceso que investigué me llevó a dialogar con ambas corrientes, cuyos aportes han clarificado gran parte de mi trabajo, pero éstas no terminaban de dar cuenta y de responder los interrogantes que fui formulando a partir de los efectos de mis intervenciones y las acciones del resto de los actores que configuraron un entramado diverso y cambiante a lo largo de todo el proceso. Estas inquietudes me llevaron a buscar más allá de las tradiciones teóricas en las que fui socializado durante mi carrera de grado y ensayar algunos vínculos entre la perspectiva etnográfica y la tarea profesional del trabajador social.

De modo generalizado se puede decir que desde la perspectiva histórico crítica, se sostiene que el sistema capitalista financiero actúa sobre los territorios para oxigenar su crisis (Dulcich, 2008) generando tierras con alto costo monetario y expulsando (proceso apoyado por las precarias políticas estatales) a las clases populares a las tomas de tierras (Vidal, 2017) ociosas y no productivas.

En tanto, la perspectiva nacional y popular sostiene la apelación a un Estado "presente", enfrentado a la lógica neoliberal, que resolvería los diferentes conflictos que van surgiendo en la trama local, sin distinguir entre los gobiernos locales, provinciales o el nacional. Para la primera perspectiva, la figura de intelectual orgánico o subalterno (Iamamoto, 1997) surge 
como respuesta posible a la pregunta sobre el quehacer profesional dentro de un proyecto ético político. En tanto, en la segunda perspectiva surge la de un trabajador social "del pueblo" que en el marco de un Estado con políticas sociales inclusivas trabajaría con la población para garantizar niveles altos de ciudadanía.

Sin embargo, en el proceso del que fui parte, no considero que haya sido un intelectual orgánico per se ni un trabajador social del "pueblo", que no desestima mi compromiso y el aporte que pude haber hecho. Mi lugar como Trabajador Social en este proceso, como lo describiré en la tesis, fue consecuencia de mis decisiones profesionales, pero con cambios permanentes de acuerdo a los lugares donde me fui insertando y en relación al agenciamiento y los modos en los cuales las redes territoriales fueron convocando e involucrándome en la toma. Lejos de las visiones normativas, morales e ideológicas de la profesión que pretenden dar definiciones estáticas sobre "lo que somos", en esta investigación pude comprobar que, si bien estas características están presentes, la práctica específica del trabajo social, no se define solo por ello, sino por el modo en que juegan los saberes, las prácticas, y las técnicas del trabajo social en una trama social especifica o en las diferentes redes existentes y sus conflictos situados en un territorio. Antes que preguntarme sobre mi identidad profesional como trabajador social (que conduce a la pregunta por el ser), preferí interpelar lo que hacía como trabajador social y cómo era apropiado y reutilizado ese hacer profesional por otros actores y actrices del mundo popular. Sintetizando, mi pregunta se centró en el hacer, y más específicamente, en el hacer con otros. Este aporte, este camino y posterior participación en "la toma" (y por supuesto el análisis de la propia toma), revistió de una complejidad inusitada para mí llevándome a la apelación de una intuición epistemológica y metodológica: la perspectiva de un sujeto en una trama y en una estructura social, donde tanto estructura como sujeto tienen su potencia, su capacidad de agencia. Fue la Etnografía la que me ayudó a elaborar esa primera intuición. Como desarrollaré más adelante, mi encuentro con la Etnografía se dio a partir de haber cursado, previamente a la Maestría de Trabajo Social, gran parte de la Maestría en Ciencias Sociales (FAHCE, UNLP) donde amplié mi capacidad de análisis a partir de las materias y profundicé mis conocimientos etnográficos por medio de cursadas específicas. Este corpus de conocimiento me permitió sistematizar y problematizar el proceso. Esta indagación estuvo guiada por los dos nudos centrales planteados en la introducción: el estudio de una toma de tierra desde la singular perspectiva de mi participación en ella como profesional y como empleado asalariado de una de las agencias del Estado Municipal del área urbana donde se desarrolló el particular nacimiento de un nuevo barrio popular. 
Mi aporte al campo del debate del trabajo social es el siguiente: considerar la observación y análisis de una trama social compleja desde un abordaje diferente, apoyándome en el rico y abundante camino de la Etnografía, pero desde la singularidad profesional, de sus dilemas, sus imperativos y estilos en tiempo real al ritmo de los acontecimientos de la vida cotidiana, en el espacio de interrelación con otras personas y actores, desde las tensiones del hacer y desde la reflexividad que surge en ese hacer, de las dificultades, los impedimentos, los atajos, las demandas dirigida hacia mí por las personas del barrio, pero también de los intentos y las construcciones colectivas, las alianzas inesperadas, la exploración y la expansión de los límites de la tarea profesional. Son estos puntos los que describo y analizo en esta tesis, sin silenciar las sorpresas, suposiciones erróneas, resistencias subjetivas, ilusiones, fracasos y logros colectivos. Participé, pero también fui llevado a participar, mis anfitriones me condujeron y me insertaron en nuevas redes para mí desconocidas, me dejé llevar y otros fueron hospitalarios y me acogieron en sus redes, con ellos recorrí este camino de mucho hacer y mucho pensar sobre el hacer.

Para presentar mi trabajo de investigación y responder mis interrogantes estructuré la tesis de la manera siguiente:

Mi escritura se basa fundamentalmente en el cuaderno de campo que escribí en ese período, donde desarrollo este recorrido, de investigación e intervención, que me llevó finalmente a estar en "la toma". La reflexión sobre mi participación allí constituye un analizador sobre el lugar del trabajo social en estos procesos desarrollados por los sectores populares. Las estrategias que desarrollé, mis temores, las dudas, los debates con otros colegas y referentes de las organizaciones, mi propia legitimidad como agente del Estado y la red informal con la cual fui trabajando, serán puestos en debate a partir de la descripción de mis intervenciones, encuentros y desencuentros, en ese lapso de tiempo.

Todos los capítulos a excepción del dos están organizados cronológicamente, relacionados unos con otros, dado que en la tesis seguí todo el proceso de la toma: desde el anuncio de la misma por parte de sus referentes hasta la consolidación de los dos nuevos barrios y la disolución de la organización que la llevó adelante.

En el primer capítulo presentaré las características sociales, demográficas y laborales de los barrios en los cuales desarrollé mi trabajo profesional. Describiré cómo a partir del trabajo asistencial me contacté con Mary, una referente barrial del asentamiento "9 de mayo", con quien armamos en conjunto con la psicóloga de la salita y los gabinetes de las escuelas, la Red contra la violencia familiar. A partir de esta Red podré profundizar el trabajo con Tania y sus compañeros, los curas de la parroquia Santa Teresa. Esto me permitió abordar, además de 
situaciones puntuales, los problemas estructurales del asentamiento 9 de mayo. Aquí se irá constituyendo una red informal de trabajo, con interdependencias recíprocas que serán la base de mi participación en la toma.

La excepción del segundo capítulo es porque consideré necesario desarrollar mis recorridos teóricos y metodológicos en torno al estudio de las tomas de tierra y mi lugar como trabajador social. Inicialmente en mis primeros años de la maestría de sociales, consideraba que éstos formaban parte de caminos diferentes y que incluso mi quehacer profesional si bien me permitía un acceso privilegiado al campo podía obturar el análisis académico. Resolver esta bifurcación que por momento bloqueaba los caminos que me trazaba, me llevó un arduo trabajo. La Etnografía, acompañada de la cursada de seminarios específicos y la supervisión de docentes, se convirtió en la clave para desbloquear y potenciar un solo recorrido donde mi intervención profesional y mi investigación se enriquecieron mutuamente en un mismo sendero.

En el tercer capítulo desarrollaré como llegué a la toma del 7 de abril, desde la habilitación de uno de los referentes hasta mi participación plena. A su vez analizo cómo se fue dando la toma de tierra y hago una breve biografía de los dos principales referentes, a quienes conocí en el marco de mi trabajo asistencial y se incluyeron en mi red informal de trabajo y yo pasé a formar parte de la de ellos. Mi participación en la toma fue siempre en el marco de mi trabajo de la salita, donde la tensión de mi lugar como profesional, fue parte constante de este proceso.

En el capítulo cuarto daré cuenta de la primera toma del 7 de abril a partir del registro etnográfico. Este primer proceso tuvo etapas diferentes y desde la denominación de los propios nativos analizaré como se dieron, contemplando a sus referentes, las intervenciones de las agencias del Estado, operadores políticos e instituciones y organizaciones sociales. Las distintas intervenciones potenciarán las diferencias entre ambos referentes y en la manera de organizarse para seguir disputando los terrenos ocupados. Mi recorrido en este proceso estará atravesado por estas condiciones y por la búsqueda individual y como parte de la red informal de trabajo de garantizar que la toma siga vigente. Esto me llevará a cuestionar mis intervenciones allí a debatir con otros colegas el por qué y para qué de un trabajador social en la toma.

En el capítulo quinto describiré las características del Centro de Participación Popular Carlos Mugica, integrante y fundador del Encuentro Territorial, en el contexto de la organización de la segunda toma del "7 de abril" que consistió en el traslado a unos nuevos terrenos, luego de meses de negociación con el municipio sin tener soluciones concretas. Aquí los referentes de la organización me invitarán para que participe de la nueva toma, lo que me llevará a tener dudas sobre cuál sería mi aporte y los riesgos a los que podría exponerme. 
En el capítulo sexto analizaré el desplazamiento a nivel organizacional y dirigencial que derivó en un traslado geográfico de la toma y en la definitiva conformación del asentamiento junto a la expulsión de la dirigencia vinculada al municipio. Aquí describiré el funcionamiento del Encuentro Territorial y desarrollaré cómo en la nueva toma confluirán diferentes tradiciones de las clases populares en torno a este tema. Un rasgo novedoso será la capacidad de este espacio para lograr la resolución de dos nuevos asentamientos, aunando la organización y disputando los terrenos a una banda vinculada a la venta de drogas. A nivel disciplinar describiré como se fortaleció mi relación con este espacio en conjunto con las residentes, en un marco de cuidados hacia nosotros por nuestro lugar profesional.

En el último capítulo desarrollaré como desde el Encuentro Territorial se me convoca a mí y a las residentes para pensar estrategias con el objetivo de obtener ayuda social por parte del municipio. Aquí frente a las maniobras dilatorias del Estado iremos debatiendo con las organizaciones que estrategia utilizar y que tipo de intervención realizar desde la disciplina. Asimismo, analizaré el cansancio y desgaste de los integrantes del Encuentro Territorial por la dilación de las respuestas del municipio y cómo se cristalizará el "apriete" por parte de la cúpula eclesiástica del Obispado de Quilmes a los clareteanos por su acompañamiento a la toma de tierra. Esto implicará un reordenamiento de ellos en el interior del Encuentro Territorial produciendo el inicio de la ruptura entre ambas organizaciones. De la articulación nacida en el 2006 y consolidada con la primera toma realizada en conjunto en el 2011 surgirán los dos barrios que sobrevivirán a la ruptura.

La conformación de los barrios 7 de abril y La cañada marcarán el final del proceso de investigación, constituyendo mi salida del campo y finalizando mi intervención allí como trabajador social en el marco de un proceso de toma de tierras. 


\section{CAPITULO 1}

\section{TRABAJAR EN VARELA}

\section{Introducción}

En el primer capítulo de esta tesis presentaré las características sociales, demográficas y laborales de los barrios en los cuales desarrollé mi trabajo profesional. A partir de la descripción de mi quehacer cotidiano, detallando los mandatos, las rutinas, los estilos de trabajo y percepciones propias y de otros actores sobre mi tarea como trabajador social, analizaré cómo fui construyendo mi lugar profesional desde el abordaje de historias singulares y cotidianas. El trabajo asistencial me permitirá contactarme con Mary y junto a los gabinetes pedagógicos de las escuelas conformaremos la Red contra la violencia familiar. Al profundizar el trabajo con la Red, el vínculo con Tania y los curas de la parroquia Santa Teresa se fortalecerá. Esta reciprocidad fue parte de un largo encadenamiento de interdependencias sociales que incluyeron mis relaciones como empleado y las tareas que me demandaba ese lugar: lo oficial, la política pública, las áreas de gestión municipal. Y por otro lado aquellas actividades que no tenían un carácter oficial, estando igualmente enmarcadas en mi trabajo lo oficioso, mis charlas y recorridas con Mary, los encuentros (y desencuentros) personales, etc. Junto a Mary fuimos constituyendo una red informal de trabajo donde articulamos el abordaje de situaciones complejas y la preocupación por los problemas en común que tenía el asentamiento 9 de mayo. Este fue el comienzo de un recorrido que luego me llevará a estar en la toma.

\section{Tentativas de un trabajador social en Florencio Varela}

En Florencio Varela comencé a trabajar en el año 2005, unos meses después de mi graduación y lo hice hasta el noviembre del 2014 fecha en la cual renuncié. En el 2006 agregué a mis jornadas laborales el trabajo en la Comisión Provincial Por la Memoria (CPM), en el área del Comité Contra la Tortura (CCT), por lo cual empecé a recorrer las cárceles de la provincia de Buenos Aires, incluidas las del complejo carcelario de Florencio Varela. A partir de estos dos trabajos, frases como "en la cárcel solo hay pobres" se llenaron de sentido para mí y en cada detenido podía ver al vecino del barrio que iba a buscarme a la salita para mejorar su calidad de vida. Se dieron varias situaciones de personas detenidas que vivían en el barrio que atendía la salita, y coordinando con sus familiares pudimos realizar presentaciones judiciales desde el CCT y, a su vez, pedidos de recursos al municipio desde el CAPS (Centro de Atención Primaria 
de Salud). Mis variadas pertenencias laborales, (además tenía una beca del Programa Médicos Comunitarios, trabajé dos años en un centro de discapacidad y participé de investigaciones del Ministerio de Salud de la Nación) me permitían tener un panorama más amplio de la realidad en la que intervenía sin embargo, esto no debe ocultar que trabajaba de lunes a sábado un promedio de $60 \mathrm{hs}$ semanales. Mi multiempleo respondía no solo a la necesidad de generar mejores ingresos frente a los bajos salarios y también como afirma Aquín N. y otros (2012: 308) por el "plus militante sustentado en el compromiso social” que diariamente me impulsaba a seguir adelante, aún resignando mi salud y mis vínculos personales. El otro aspecto (parte de las mismas condiciones laborales) era el área programa que debía cubrir con mi empleo, que comprendía cuatro barrios La Esmeralda, Santa Rosa, Libertad, Villa Susana dos asentamientos 9 de mayo y 10 de febrero, con un total de población de 25.000 personas y una asistencia en promedio de 100 por semana en promedio al CAPS, entre consultas en sede y visitas a domicilio. $^{1}$

El Centro de Atención Primaria de Salud (en adelante CAPS o salita) La Esmeralda, se ubica dentro del área III. En su área programática están los barrios mencionados, cuyas superficies son:

Villa Susana: Superficie: $0.192 \mathrm{~km} 2$

La Esmeralda: Superficie $0.915 \mathrm{~km} 2$

Libertad: $\quad$ Superficie $0.57 \mathrm{~km} 2$

Santa Rosa: $\quad$ Superficie $1.53 \mathrm{Km} 2$

La superficie total: $3.027 \mathrm{Km} 2$.

En el posgrado Médicos comunitarios como parte del trabajo realicé un relevamiento de estos barrios, en base a la composición etaria, las características de las viviendas y servicios generales, el saneamiento ambiental y los problemas sociales predominantes. El relevamiento en conjunto con el aprendizaje que iba adquiriendo en las visitas que realizaba me permitió tener un conocimiento amplio de los mismos.

\footnotetext{
${ }^{1}$ Cuando comencé en 2005 en Florencio Varela había en el Primer Nivel de Atención de Salud 33 Centros de Salud, divididos en tres Áreas Programáticas Regionales, el Área I agrupaba a 9 CAPS., el Área II a 11 y el Área III a 13. Todos dependientes de la Secretaría de Salud del municipio. El gran "logro" (eso me dijeron apenas comencé a trabajar) de la conducción de Desarrollo Social de esa época, era que habían logrado garantizar que haya un "social" (trabajador social) por CAPS. La atención de cada colega en cantidad de personas variaba según factores (confianza de la población en el colega, trabajo territorial, interconsultas del equipo, voluntad, etc.), en tanto había colegas que tenían áreas poblacionales más numerosas (por ej. Ricardo Rojas con 40.000 habitantes) y otros con menos. Sin embargo, nadie tenía a cargo una población menor a 10.000 habitantes.
} 
Los barrios más antiguos del área y con mejor dotación de servicios eran La Esmeralda y Villa Susana donde predominaba la población media y madura, cuyo reflejo era la constitución del Centro de Jubilados en el barrio la Esmeralda con una gran presencia de personas mayores. Las familias estaban caracterizadas por ser nucleares, ampliadas y extensas, aunque también se observaba adultos mayores viviendo solos. Había adolescentes pero no en cantidad significativa en comparación con los asentamientos o el barrio Santa Rosa. Aquí se encontraba la Escuela Primaria Básica n. ${ }^{\circ} 20$ y Escuela Secundaria Básica donde concurrían niños de los cuatro barrios.

Las viviendas eran en su mayoría de material, algunas con techos de tejas, de chapas acanaladas, losas y aberturas de madera o aluminio. Muchas tenían espacios verdes. En su gran mayoría las casas poseían dos o más habitaciones dormitorio. Los pisos de las viviendas eran de baldosas, mosaicos o cerámicos y algunas con contrapiso únicamente. A su vez se observaba la presencia de casillas de madera pero en número reducido y generalmente al fondo de un predio familiar, donde la familia nuclear le cedía a algún integrante el espacio para erigir su vivienda. Generalmente de estas familias era de donde surgía la demanda mayor para mí en lo asistencial, dado que se encontraban en procesos de empobrecimiento. En varias ocasiones al visitarlas me manifestaban la "vergüenza" por pedir "ayuda" y me aclaraban que años atrás jamás lo hubiesen hecho.

Asimismo era notorio la diferencia entre las viviendas establecidas sobre las calles con asfalto que generalmente poseían veredas amplias y con césped recortado y las que estaban sobre calle de tierra, que carecían de veredas y tenían zanjas que bordeaban las calles. En el barrio Villa Susana predominan las primeras y en La Esmeralda las segundas.

En las reuniones que fuimos teniendo desde la salita con los vecinos relataban que en relación al saneamiento ambiental, estaban preocupados por la falta de recolección de residuos, los desechos del frigorífico El Látigo, la ausencia de espacios verdes y las zanjas que bordeaban numerosas calles. Por ello realizamos numerosas notas de reclamo al municipio, las cuales no tuvieron éxito en la resolución.

Por otro lado, sobre los problemas sociales predominantes los gabinetes pedagógicos de las escuelas referían su preocupación por la gran cantidad de situaciones de violencia familiar que incluía: maltrato y abuso infantil, maltrato personas mayores y personas con discapacidad. Esta preocupación sería fundamental para que participaran del armado de la Red contra la violencia. El barrio más extenso y poblado del área era Santa Rosa con una superficie $1.53 \mathrm{~km}^{2}$. Este barrio me solía llevar mucho tiempo recorrerlo. En los años anteriores a mi ingreso había experimentado un crecimiento acelerado que marcó diferencias, generando cinco diferentes 
nombres según la zona: Santa Rosa Vieja, Santa Rosa Nueva, Santa Rosa Rural, el Asentamiento 10 de febrero y el Complejo Habitacional del Plan Federal de Viviendas (que no pertenecía al área del CAPS). Santa Rosa Vieja limitaba con La Esmeralda por la calle Bélgica y era el único de estos barrios que se encontraba del otro lado de la Avenida Novak. Sus características eran similares a los de La Esmeralda, en cuanto a la población y a las viviendas. En Santa Rosa Vieja se encontraba la Escuela $N^{\circ} 19$, un jardín estatal y uno privado. Asimismo, estaba el Instituto Biológico Silvio Dessy que producía insumos y sueros. Este barrio era el que más me gustaba visitar por sus árboles enormes y sus avenidas amplias. No tenía demasiadas consultas en comparación con otros barrios. Santa Rosa Nueva limitaba con Villa Mónica por la calle Paysandú, con Libertad por la calle Humahuaca, con el Complejo habitacional y la zona rural por la calle Rumania, en tanto de Santa Rosa Vieja la separaba la avenida Novak. Aquí en la zona baja ubicada en el centro geográfico del barrio se encontraba el Asentamiento 10 de febrero con seis manzanas. La población predominante era joven y mediana con familias multideterminadas: extensas, ampliadas, nucleares, monoparentales con promedio de tres a cinco hijos por familia. En la época de temporales solía haber inundaciones, voladura de techos y destrucción de viviendas, en esos días a veces atendía más de 400 personas en una semana, siendo la mayoría eran del asentamiento y de Santa Rosa Nueva.

En éste último las viviendas generalmente eran pequeñas o medianas, de construcción de material pero deterioradas e incompletas. Existían viviendas de buena construcción con servicios completos, pero eran escasas y sus integrantes trabajaban en el ámbito privado o eran referentes políticos del municipio. El piso de las viviendas era mayormente de cemento o contrapiso. En el asentamiento las viviendas eran de madera con techos de chapas de cartón o zinc y los pisos de tierra.

Mis visitas en el verano las armaba tratando de caminar por las calles que tenían árboles porque el calor se sentía mucho, en cambio en invierno las diagramaba por las avenidas para evitar las calles arcillosas, aunque siempre terminaba transitándolas y mojándome. En mis años de trabajo me parecía bien hacer las visitas incluso con lluvia sin importar el clima ni el riesgo de los cables caídos en la calle. Con el tiempo fui dándome cuenta que esto era bien visto por las personas del barrio, al contrario de mis compañeros de la salita que me advertían de los riesgos de este tipo de decisiones.

En Santa Rosa todos los terrenos estaban ocupados prácticamente no quedaba espacio libre. Había veredas realizadas por personas con planes municipales aunque eran las menos. Mayoritariamente los habitantes tenían servicio de red eléctrica y gas envasado (garrafas). No disponían de servicio de cloacas ni de gas en red. De este barrio tenía numerosas consultas y 
pedido de visitas para realizar encuestas sociales a pesar de ello en mis años allí, no terminé de conocer a toda la población y además era un bastión del partido justicialista (en adelante PJ) y de la municipalidad con una presencia cercana a los cien referentes políticos. ${ }^{2}$

En Santa Rosa Rural las viviendas eran mayormente casillas de madera con contrapiso o piso de tierra, precarias, sin servicios básicos, el agua solía estar contaminada, con olor nauseabundo. Utilizaban conexiones clandestinas para obtener luz eléctrica. Era una población escasa y estaba conformada por familias de hasta tres generaciones. No obstante, por ser una zona con muchos terrenos libres (ex chacras) en los años siguientes muchas tomas de tierras se realizarían allí. Otros problemas cotidianos era la basura acumulada en esquinas, la mala recolección de residuos y el agua contaminada. Al igual que en La esmeralda uno de los problemas sociales predominantes que preocupaban a la población y en especial a algunas de las instituciones, era el de la violencia familiar que incluía maltrato y abuso infantil, maltrato a personas mayores y personas con discapacidad. El abuso sexual a niños y niñas era un problema grave e incluso la población había tomado acciones como la quema de viviendas de abusadores. En este barrio, en mis primeros años de trabajo me convocaron para dar charlas de VIH, trabajar situaciones de abuso y de personas mayores abandonadas, lo que me permitió insertarme y conocer al Centro para personas con discapacidad Ruca Hueney, una organización solidaria y autónoma con la cual coordinamos estrategias de abordaje y hasta la ayuda a los nuevos asentamientos.

Libertad era otro de los barrios que había tenido un gran crecimiento poblacional a partir del 2002 con los asentamientos 9 de mayo y 9 de febrero, el primero perteneciente al área del CAPS. En el Asentamiento 9 de mayo la población predominante era joven y mediana, con familias multideterminadas: extensas, ampliadas, nucleares y monoparentales, con un promedio de tres a cinco hijos por familia. Había una gran cantidad de adolescentes de los cuales una gran porción eran padres de familias o madres solteras. Las viviendas eran pequeñas de construcción muy precaria, de madera, techos de chapas de cartón, o también había casas construidas en su totalidad de chapas. El piso de las viviendas era de tierra, algunos habían construido un contrapiso de cemento. Mayoritariamente las viviendas poseían una sola habitación dormitorio. Todos los terrenos estaban ocupados y se observaban dos o más casas construidas por terreno. No había veredas y las calles estaban al mismo nivel que los terrenos, con zanjas colmadas de agua estancada que bordeaban las calles. La electricidad en el asentamiento 9 de mayo era por conexiones clandestinas y se utilizaba el gas natural envasado

\footnotetext{
${ }^{2}$ Cada vez que había problemas en este barrio (piquetes, manifestaciones, cortes de ruta, etc.) los administrativos de la salita (algunos eran militantes del Partido Justicialista) contaban la indignación de "Julio" (Pereyra, intendente) que no podía creer que con tantos militantes se les "escapaba" el barrio de las manos.
} 
(garrafas) para la cocción de alimentos. Este asentamiento por la presencia de organizaciones sociales (el Centro Mugica, el movimiento Martín Fierro, el MTD Aníbal Verón) solía tener mucha capacidad de movilización y había protagonizado los intentos más fuertes por el mejoramiento ambiental. A través de delegados elegidos por elecciones y movilizaciones al Municipio, con cortes de calles incluido, habían reclamado la recolección de residuos, la electrificación y el saneamiento general con las sanciones establecidas al frigorífico. El reclamo más fuerte era por el agua que estaba contaminada con nitritos, nitratos y bacterias, afectando a un gran porcentaje de la población. Este asentamiento fue una de mis prioridades desde que comencé a trabajar en la salita, lo que se correspondía con el afecto que me prodigaban en mis visitas, recibiéndome con mate, tortafritas e incluso jugo o tereré los días de calor.

En el resto del barrio Libertad la situación era más heterogénea, la población difería y había adultos mayores y adultos con menos presencia de adolescentes. Las casas generalmente eran de material y estaban en un estado regular de conservación. Aquí tenía mucha presencia la UGL (Unidad de Gestión Local) donde la "Huanca", la referente del PJ, me solía recibir con mates y sonrisas para contarme la preocupación por alguna familia del barrio.

Al igual que en La Esmeralda y Santa Rosa, uno de los problemas sociales predominantes que preocupan a la población era el de la violencia familiar. Otros problemas se referían a la desnutrición, las infecciones respiratorias, la deserción escolar y las adicciones.

El origen de la población en estos barrios variaba; en La Esmeralda y Villa Susana, se encontraban personas que provenían de diversas provincias del país pero mayormente eran originarias de Florencio Varela. En el barrio Santa Rosa y los asentamientos había una fuerte presencia de migrantes del norte (Formosa, Chaco, Santiago del Estero, Tucumán) y de países limítrofes (Bolivia, Paraguay y Uruguay en menor medida). Igualmente predominaban los argentinos y muchas familias venían desde distintos barrios de Varela.

En cada visita o entrevista en la salita, las personas me contaban sobre las actividades laborales que hacían y éstas también se diferenciaban de acuerdo a las características de los barrios que componían el área programática. En los barrios más antiguos se podía encontrar a comerciantes, trabajadores fabriles, operarios, profesionales. No obstante, también había changarines, cartoneros, cuentapropistas y vendedores ambulantes. En los asentimientos y Santa Rosa la población económica activa se dedicaba a la construcción sin contratación y de forma temporal. Había personas empleadas en el frigorífico informalmente, otros eran recolectores de cartón, vendedores ambulantes, y/o personal doméstico. La gran mayoría alternaba estas estrategias en pos de sobrevivir y de acuerdo a las posibilidades que ofrecía el mercado. Asimismo un gran porcentaje contaba con planes sociales, pensiones o programas alimentarios, los cuales no 
garantizaban la subsistencia. En estos programas mi trabajo era demandado para los informes sociales. Para cada informe correspondía una visita, eso lo había aprendido claramente en los reclamos que me hacían: "quiero que vea como vivo, que ponga todo eso en la encuesta"; incluso si no hacía la visita (a muchas personas ya las había visitado varias veces) se enojaban conmigo. Las personas que iban a verme eran en su mayoría mujeres acompañadas por sus hijos, nietos, que solían organizarse para ver a otro profesional de la salita y a mí, con la ventaja que yo atendía sin turno por lo cual podían verme en cualquier momento. A veces, cuando las consultas superaban las 25 en el día, les pedía por favor si podían venir otro día (les explicaba que "no me daba más la cabeza") a lo cual accedían sin problemas.

\section{2. “Luciano, hablás como los piqueteros." Mandatos, rutinas, estilos de trabajo y percepciones de la tarea de un trabajador social.}

La gran mayoría de la población de estos barrios se situaba en el campo de intervención para el trabajo social, ya que estaban compuestas por personas cuyos procesos de reproducción de la existencia presentan dificultades y acumulación de desventajas (Bayón y Saraví, 2006). ${ }^{3}$ Y las respuestas a estas dificultades estaban dadas por recursos de políticas sociales precarias y focalizadas (Borgianni et al, 2003). ${ }^{4}$ En este proceso de distribución secundaria del ingreso (Aquín, 2013) el trabajador social adquiría para el gobierno local una importancia fundamental. La primera condición establecida por el área de desarrollo social municipal era la evaluación de un profesional por medio de una planilla ya confeccionada o una encuesta social; para ambas se solicitaba una evaluación final sobre la condición socio-económica de la familia. Sin embargo que el trabajador social "evaluara" la pertinencia de entregar un recurso o inscribir a una persona en un programa, no significaba su concreción dado que intervenían otros factores. ${ }^{5}$ A cada persona que atendía le contaba cómo era el circuito que realizaría su pedido: primero la

\footnotetext{
${ }^{3}$ En algunas áreas como los asentamientos, se observan indicadores de $91 \%$ de NBI, aunque esto no es privativo de los barrios históricos, según datos relevados en el marco del relevamiento realizado en el marco del PROMEBA (programa de mejoramiento barrial en el 2010).

${ }^{4}$ Sin desconocer los avances en materia de derechos sociales generados en los años 2003-2015, difiero con Aquín (2013) sobre que el trabajo social intervenía en ese momento en contextos de "aceptable universalidad, con garantías de acceso a salud y educación..." Sin entrar en el análisis del periodo kirchnerista, lo que yo visualizaba era que el acierto de la implementación de muchas políticas sociales, como la AUH (asignación universal por hijo) las políticas de viviendas, las previsionales, entre otras, no habían podido (en este caso específico del 2011 en esa zona de Florencio Varela) revertir mínimamente los efectos estructurales de la pobreza.

${ }^{5}$ En el 2008, en el marco de un artículo para una revista sindical, con unos colegas publicamos el articulo (sin demasiada profundidad teórica pero valiosamente descriptivo), que posteriormente se presentó en el segundo foro latinoamericano, donde analizábamos cómo era el recorrido de la encuesta social A este abordaje institucional lo llamamos El circuito asistencial-focalizador-burocrático-clientelar y describíamos en detalle desde la llegada de la demanda hasta la resolución.
} 
encuesta era enviada a Desarrollo Social donde se cargaba en una base de datos para cruzarlos con anteriores entregas de recursos, luego debían concurrir al área de Emergencia Social donde eran recibidas por un equipo de administrativas y trabajadoras sociales que leían la encuesta y "evaluaban" nuevamente la pertinencia del pedido. Sin embargo, la jefa del área (una administrativa con varios años de trabajo) era quien definía de acuerdo a las órdenes que le habían dado desde el municipio, los recursos en depósito y sus propios criterios. Muchas veces debí llamar a Desarrollo para "convencer" a Clarita (así se llamaba) que entregue los recursos y otras tantas veces recibí su llamada para "retarme" por una reiteración de pedidos o una persona que no "merecía" el recurso. Estas aclaraciones no evitaban que en momento de crisis económica o situaciones provocadas por los temporales, muchas personas del barrio se dirigieran a mí como el mayor responsable de la entrega de recursos.

Las políticas sociales en Florencio Varela asignaban al profesional un lugar asistencial ligado a los recursos básicos por medio de la certificación de pobreza, en un contexto de sobredemanda $^{6}$, dado que cada trabajador social tenía a su cargo áreas de más de 20.000 personas. La certificación profesional a su vez era exigida por los programas nacionales para pensiones, tarjetas de alimentos, recursos ortopédicos, eximición de tasa migratoria. No primaba el interés en el informe sino en que el trabajador social quedara frente a la población como el intermediario calificado para la obtención de recursos. Por ello mismo, la responsabilidad de la no obtención de los recursos también recaía sobre nosotros. El profesional quedaba situado como el mediador de los conflictos:

...como si éstos se resolvieran comportamentalmente y por la acción del profesional. En tal sentido, la dinámica de las demandas emergentes e inmediatas parece colocar al asistente social en una calesita de respuestas inmediatas (Montaño, 2009:16).

Este lugar era el exigido por la Secretaría de Desarrollo Social, donde cada dirección de asistencia monitoreaba y reclamaba el informe social correspondiente en tiempo y forma, so pena de iniciar sumarios al profesional y/o de "presionar" por medio de referentes territoriales que operaban en el barrio a través de amenazas y acusaciones directas ("vos no querés ayudar

\footnotetext{
${ }^{6}$ La demanda al Servicio social puede ingresar por estas vías: demanda espontánea (turnos en el Centro de salud), Vía organizaciones barriales (UGL, Movimientos sociales, etc.) Vía sistema de carta elevada al Municipio o Call center (un 0800 que recepciona "demandas" de los vecinos del distrito y luego las mismas siguiendo circuito administrativo llegan al Trabajador Social dependiendo del barrio de donde sea la persona que lo ha solicitado), Vía programas externos (pensiones) Vía Desarrollo Social por demanda de concejales o referentes barriales, Vía Desarrollo Social (derivaciones de situaciones recepcionadas allí y/o de las distintas direcciones) Vía Desarrollo Social de Nación, Vía Municipio en sus diferentes Secretarías.
} 
a la gente") o desgastando la imagen del profesional por medio de rumores, criticas, etc. En épocas de temporales, tanto la Secretaría de Desarrollo Social como los referentes territoriales, le comunicaban a la población de cada barrio que los reclamos por voladuras de techos, incendios, inundaciones, debían hacerlo con el trabajador social. ${ }^{7}$

En este contexto, era posible quedar saturado por la demanda y las presiones que llevaban a: ..."preocuparse" y a actuar de forma inmediata sin crítica, sin buscar la transformación, sólo algunos cambios inmediatos, localizados, que respondan a sus carencias directas; actúa de modo desarticulado, inmediato, directo, en los "problemas" singulares, en una realidad des-totalizada, des-economizada, despolitizada, inmutable, sin historia. Este agente deja de ser sujeto, pasa a materializarse en un sistema supra-histórico. Ya no se hace (ni se piensa en) la Historia, sino apenas en historias, singulares y cotidianas" (Iamamoto, 1992:17)

La cita precedente, de una de las autoras más destacadas de la "perspectiva histórica critica del trabajo social" con la cual me formé en varios años de mi carrera, encarnaba para mí en un mandato fuerte: "el trabajador social se tiene que hacer cargo de La Historia", el mismo reforzado a su vez con mi trayectoria de militancia en agrupaciones de izquierda. La fuerza analítica de esta perspectiva me permitía leer la realidad macro-estructuralmente y el aspecto crítico con respecto a la desarticulación y la fragmentación, pero en mi ámbito laboral se tornaba en un mandato, en una acusación que me hacía a mí mismo, generándome frustración por no poder hacer acciones transformadoras. Asimismo y contradictoriamente me impulsaba a profundizar mi trabajo de compromiso con los problemas estructurales del barrio ${ }^{8}$.

Frente a este escenario complejo, mi formación de grado me había dado herramientas teóricometodológicas para comprenderlo y actuar en él. Desde el primer año de la carrera transitamos materias que nos permitían comprender el neoliberalismo, las políticas sociales, la cuestión social, incluso en cada año se debatía sobre el origen de la profesión, los intereses en pugna y la importancia de "resignificar" la demanda que nos llegaría como profesionales para lograr que nuestra intervención tuviera un sentido crítico que velara por el cumplimiento de los derechos humanos.

\footnotetext{
${ }^{7}$ http://www.varelaaldia.com.ar/archivos/articulo/1823/encendida-defensa-de-los-asistentes-sociales-de-laasociacion-de-profesionales-de-la-salud En este artículo periodístico se puede ver la respuesta del sindicato, defendiendo a los trabajadores sociales, a quienes el diario "Varela al día" acuso "no querer ayudar a los pobres" ${ }^{8}$ Para ampliar la potencia y límites de esta perspectiva se puede consultar el libro de Karen Healy (2015).
} 
Considero que es necesario reflexionar críticamente sobre este mandato profesional. Más allá de menciones y debates no encontré bibliografía específica que lo haya tomado como un foco de análisis. En primer término este mandato tiene como trasfondo el debate sobre el derecho a la asistencia, el "asistencialismo" y las prácticas "reivindicativas". En mi carrera de grado y en mis años de Varela, solía ser un insulto la acusación de "sos un asistencialista" o "haces asistencialismo". Estas acusaciones en realidad querían expresar que el trabajo asistencial (la gestión de recursos) si no era cuestionado con otro tipo de práctica "transformadora" se estaba reforzando "al sistema capitalista". No fue casualidad que la referente del comedor del barrio un día me dijera: "Luciano, hablás como los piqueteros." Esta frase si la ubicamos en su contexto de relaciones puede ser reveladora de las percepciones de los otros sobre mi tarea en la salita. Y lo voy a presentar aquí como uno de los primeros indicios de la reflexividad colectiva del entramado de relaciones sociales por el que me movía en Varela.

En esta sucinta pero certera frase se condensaba mi búsqueda de realizar una práctica "reivindicativa" (Oliva, 2015). Desde mi punto de vista la noción clave de mi trabajo era "resignificar" la demanda. Y esto básicamente consistía en que la demanda (asistencial) que "traía" la persona (pedido de alimentos, chapas, etc.) debía ser una oportunidad para trascender ese pedido y trabajar con las personas otros problemas que tuviera "más graves" y a los cuales se los situaba dentro de las refracciones de la cuestión social. ${ }^{9}$ Darle otro significado a la demanda era mi búsqueda en la intervención profesional.

La perspectiva sobre la tarea asistencial que desarrollan Campana y Servio cuya búsqueda es “...la asistencia social como derecho y sobre el carácter estratégico del "rescate" de la asistencia social de su histórico sesgo peyorativo y residual, en el marco de una disputa por el sentido de la protección social” (2014:1) puede resultar de utilidad para ampliar el análisis de este problema. Estas autoras señalan que desde la disciplina se tiene "fobia" a la dimensión "asistencial" de su intervención y buscan discutir a la asistencia social como un derecho fundamental y luchar para que sea parte de un servicio público universal. Por mi parte considero que lo importante no es la diferencia entre estas corrientes (la perspectiva histórico crítico y la de la asistencia como derecho) dado que comparten, en fin, la idea de la ampliación de los derechos de la clase trabajadora y la ampliación de los servicios que los garanticen (Oliva, 2015; Campana, 2014), sino que se debe pensar este debate más allá de posiciones maniqueas y panfletarias vinculándolo a las necesidades de la población y las posibilidades de los

\footnotetext{
${ }^{9}$ Para Netto (1997) desde las ideas liberales, se lleva a encuadrar a los grupos afectados por las refracciones (los problemas sociales generados por la desigualdad social) de la 'cuestión social' como problemas personales, privados e individuales.
} 
profesionales con los pies en el territorio. Como se verá a lo largo de esta tesis, asistir y realizar prácticas reivindicativas no fueron dos posiciones excluyentes, por el contrario se nutrieron mutuamente.

En mi trabajo en Varela pensaba que desde las tareas básicas, administrativas, inmediatas y urgentes, y a partir del potencial de las entrevistas propias de nuestra disciplina (Mallardi, 2011) que mantenía en el consultorio, podía gestarse la legitimidad en la población del barrio que permitiría la inserción en el territorio. Esto podía constituirme en un profesional que pudiera trabajar situaciones complejas como violencia de género, abuso sexual infantil, consumo problemático de sustancias, entre otros, y aspiraba con ello a estar al servicio de las organizaciones sociales. Mi labor en Varela se fue construyendo desde esas miles de historias singulares y cotidianas, que escuchaba en el consultorio de la salita, bajo la atenta mirada de un retrato del Che Guevara y una bandera de Cuba que había colocado arriba de la puerta de modo que solo yo podía verlo. Esas personas que confiaban en mí para contarme sus pesares, tristezas, necesidades y pequeñas alegrías, que me recibían en su casa con mate, tereré, agua o jugo, me impulsaban a pensar qué hacer para aportar al mejoramiento de su calidad de vida. Pero contrariamente a lo que pueden despertar la presencia de ciertos símbolos personales no lo vivía románticamente. Estas tareas podían limitar la práctica profesional cotidiana dado el contexto donde se desarrollaban y estaban atravesadas por el diseño de políticas públicas sin recursos, una gran población en el área y las tensiones con las expresiones políticas del partido gobernante.

En el cuaderno de campo que escribí en el año 2011 están reflejadas algunas situaciones que iluminan el trabajo cotidiano.

Extracto del cuaderno de campo. Lunes 28 de marzo del 2011. Atención en el CAPS.

“...atendí unas 15 personas (...) vinieron dos paraguayos del barrio Santa Rosa para que le realice la eximición de tasa migratoria o "carta de pobreza" como ellos lo llaman. Otra señora, de 55 años, del barrio Libertad, concurría por el pase libre (...) le explique que lo hacían en el hospital Mi Pueblo y que debía sacar turno ahí, ya que desde la salita no nos dan, la señora me dijo que era analfabeta y que nadie la tomaba en serio (...) También debo reclamar por su tarjeta Varela Incluye ya que nunca la usó (...) le dieron de baja, en Desarrollo Social le dijeron que "se deje la tarjeta de recuerdo". 
Al mediodía fui al Centro de personas con discapacidad Ruca Hueney (...) Nos reunimos por la situación de Paola, una chica con discapacidad, maltratada por la familia, abusada desde chica, ahora tiene una hija, luego de que la propia madre la “canjeo” con otro paraguayo por una construcción de una pieza.

(...) Luego, en la puerta de mi consultorio, me esperaba una mujer llorando, la hice pasar, es un caso de la hija, de 3 años, con leucemia, en el Hospital de Niños de La Plata le piden que tenga un dormitorio con varias condiciones, yo le hice un informe social en octubre, pero no le dan respuesta desde el municipio (...) Le digo que voy a reclamar pero que ellos se junten, que le hagan una carta al intendente y una copia a "Varela al día" que solamente unidos pueden luchar.

(...) Al salir entra otra señora, también le hice varias encuestas por la casa, quemada en el 2004, hay peligro de derrumbe, una parte es de barro. Viene con una nota de la $U G L^{10}$ pidiendo otra encuesta..."

Mi tarea estaba muy asociada a la focalización de las políticas sociales dirigidas a la pobreza y las limitaciones en los tramites requeridos por ejemplo para el derecho a la nacionalización se debía acreditar un certificado de pobreza con dos testigos; para el derecho a la alimentación se otorgaba una tarjeta de $\$ 80$ mensuales ${ }^{11}$ incompatible con programas de pensión o jubilación y con cupos fijos establecidos por municipios y sujetos a los vaivenes de las decisiones ministeriales que daban altas o bajas de la tarjeta para las condiciones habitacionales se requería una encuesta social que funcionaba como certificado de pobreza donde calificaba a las personas en merecedores ${ }^{12}$ o no de la asistencia y legitimidad del pedido. En este proceso de implantación cotidiana de las políticas sociales mi tarea como trabajador social se constituía en un medio de “certificación" de accesos focalizados a recursos de por sí escasos. La pobreza antes que fruto de las desigualdades extremas o la ausencia de capitales sociales básicos, sólo se terminaba de configurar cuando era legitimada o certificada por mis informes, notas y/o formularios. Pero aún habiendo obtenido "mi certificación", los pobres del barrio deberían seguir haciendo un

\footnotetext{
${ }^{10}$ Unidad de gestión local. Entidad intermedia creada por el municipio para nuclear reclamos en el barrio. Cassano y Krakowiak (2000) refieren que están compuestas por representantes de las instituciones barriales y presididas por el presidente de la Sociedad de Fomento para en el 2003 se habían constituído 74 UGL que cubrían el 90\% del distrito.

${ }^{11}$ El Plan Nacional de Seguridad Alimentaria del Ministerio de Desarrollo Social de la Nación se aplica en todo el país. En Florencio Varela hasta el año 2014 era de $\$ 80$ por mes (unos 10 dólares).

${ }^{12}$ Silvana Darré (2005) en su artículo "Madres inapropiadas, maternidades problemáticas" desarrolla estas lógicas y los premios que instituía la Sociedad de Beneficencia a los pobres "virtuosos" "resignados". Estas categorías aún subyacen en las direcciones y empleados de Desarrollo Social. En línea http://agendadelasmujeres.com.ar/index2.php? $\mathrm{id}=3 \&$ nota $=1121$ Asimismo hay presencia del discurso desde la neofilantropía.
} 
largo recorrido que tampoco dependía de mi voluntad ni de mis esfuerzos sino de una extensa cadena de mediaciones políticas y sociales hasta encontrarse (en el mejor de los casos) con el recurso o la asistencia que estaban necesitando. ${ }^{13}$

Sin embargo aunque tomaba mucho de mi tiempo no me dedicaba sólo a "certificar". También una actividad tan monótona y rutinaria como esa podía ser una oportunidad para poder trabajar con los relatos de las propias personas como refiere Mallardi: "Es preciso, entonces, reconstruir a partir del diálogo cómo esa situación que aparenta ser aislada y propia de ese sujeto encuentra sus causas en la totalidad en la cual se desarrolla" (2011:7).

En este ejercicio encontraba límites dado el ritmo de trabajo cotidiano y la cantidad de consultas que recibía. Además, referirle a cada persona que su situación era parte de un sistema social basado en la desigualdad, requería tiempo y tacto. Más de una vez recibía llamados desde Desarrollo Social donde mi jefa me recriminaba que mis "pacientes" se ponían "agresivos" y referían que ellos tenían "derechos", que el "asistente social del barrio me dijo que ustedes me tienen que dar" o directamente, como me dijo aquella referente de un comedor que respondía políticamente al municipio "Luciano, hablas como los piqueteros".

Esto me hizo pensar que mi búsqueda por desnaturalizar la pobreza y denunciar sus causas y las intervenciones de las agencias del Estado podía tener otras lecturas o situarme sin que sea mi objetivo en la trama del barrio y las disputas.

En efecto, Norma entendía muy bien de qué estaba hablando y sabía que yo también entendería. Antes de responder políticamente al municipio había sido parte del MTR (Movimiento Teresa Rodríguez), por lo cual su interpelación en el contexto de una charla que estaba dando sobre VIH en su comedor me confundió y me hizo pensar sobre mi manera de hablar y a desnaturalizar mis intervenciones. Con su sonrisa y su frase, celebrada por las carcajadas amenas del resto del comedor, me situó en un lugar y me dio impulso a reconocer los efectos específicos de mis intervenciones en esa trama social asociándome a uno de los actores de allí y me reveló justamente que me encontraba en una trama específica y concreta.

Comencé a cuestionarme las categorías que utilizaba, las cuales muchas provenían de mi militancia en un comedor piquetero y en una agrupación de la facultad. Empecé a preguntarme sobre la importancia de ser estratégico en un contexto nuevo y desconocido para mí. Con una

\footnotetext{
${ }^{13}$ Para Salomone (2015) subyace una concepción de hombre poseedor de necesidades básicas (incluyendo aquellas que hacen a la subsistencia). Parten del reconocimiento de la heterogeneidad y diversidad de las situaciones sociales de pobreza y vulnerabilidad social y, mediante la utilización de criterios de selectividad positiva se concentran en la adecuación del servicio a las necesidades del receptor, se centran en la demanda. Supone la idea de un Estado subsidiario: debe limitarse a beneficiar a aquellos hogares que no están en condiciones de atender por sí mismos sus necesidades básicas más urgentes. En síntesis, el Estado asume como responsabilidad principal en la temática social garantizar las necesidades básicas de la población mediante políticas sociales compensatorias.
} 
certera frase Norma me puso en alerta y desató un nudo reflexivo que permanecía latente y en tensión en mi propia experiencia como novel trabajador social.

\section{María la del barrio. Visitas, recorridos y aperturas del compromiso profesional.}

Trabajar en Florencio Varela fue para mí insertarme y conocer un mundo de instituciones estatales, organizaciones sociales y de la iglesia. En el trabajo diario de entrevistas por pedido de recursos: las chapas, la mercadería, la pensión, etc., entendí que para las personas del barrio mi visita domiciliaria era fundamental para que yo constatara sus condiciones de vida, "vea como vivo" me repetían una y otra vez, lo cual contrastaba con mi idea de que eso era control social. Mi atención entonces comprendía una primera entrevista en el CAPS donde las personas me pedían una encuesta social para determinado recurso, luego mi visita domiciliaria y por último una nueva entrevista en el CAPS donde completaba la planilla. En esas instancias entre entrevistas y visitas se iba generando una cercanía con las personas que permitía conocer otros problemas de cada familia (problemas tan variados como económicos, de adicciones, violencia de género, maltrato infantil, problemas entre vecinos, de recolección de la basura, de presencia de roedores, etc.) y además las propias personas me iban referenciando con otras instituciones u organizaciones donde concurrían. Así conocí a Mary.

A mediados del año 2005, apenas ingresado en la salita, comencé a realizar visitas domiciliarias. La modalidad que elegí para mis primeras visitas en el asentamiento 9 de mayo fue hacer un listado donde cada persona que yo debía visitar me pasara a buscar por la casa del vecino que figuraba antes en el listado en un horario acordado. De esta manera no corría riesgo de perderme en el asentamiento. Si bien al principio funcionó bien (gracias a la paciencia de las personas del barrio con el "asistente o visitador", como solían llamarme) consideré a los pocos meses, que era mejor el riesgo de perderme o deambular preguntando casa por casa hasta encontrar a determinada persona así de esta manera podía conocer el barrio. En ese trabajo, pronto comencé a recibir la ayuda de María Elena Herrera quien tenía una "copa de leche" en uno de los paredones traseros y lindantes a la cancha de Defensa y Justicia. Mary, como solía gustarle que la llamen, había nacido un 26 de julio en Villa Angela (Chaco) y llegado a los ocho años a Lanús y en su primer matrimonio se había mudado a Florencio Varela.

Cada jueves o viernes pasaba a verla pidiéndole ayuda para ubicar a las personas. La "copa de leche" había sido construida frente a su casa y ambas se ubicaban a una cuadra de la calle principal, la avenida Humahuaca la única calle asfaltada que dividía los barrios Libertad y Santa Rosa. Muchas veces Mary me acompañaba hasta la puerta de la casa y en el camino me expresaba sus preocupaciones por la situación de alguna familia o por las malas condiciones 
del barrio. Mary sabía ser reservada y no juzgar a las personas, lo cual me aliviaba ya que me encontraba cansado de escuchar en la salita cómo algunos de mis compañeros de trabajo se referían a las personas del barrio desde el desconocimiento y el prejuicio. En el invierno y los días de lluvia debíamos caminar agarrados a los alambrados de las viviendas para evitar las lagunas inmensas de las calles. En esas visitas Mary me iba contando de a poco su historia en el barrio su trabajo en la "copa de leche":

El asentamiento 9 de mayo tomaba el nombre por la fecha en la cual un grupo de personas habían entrado a esos terrenos. Tres años antes de la toma Mary vivía sobre el asfalto muy cerca de lo que sería el asentamiento. En esa casa del barrio Santa Rosa había vivido doce años hasta que por problemas personales tuvo que mudarse a una casa que compró en otro asentamiento llamado 3 de julio donde vivió tres años. Al enterarse de la toma alertada por sus amigas de su antiguo barrio, decidió dejar su casa y volver con sus antiguos vecinos para conseguir un terreno. Mary recordaría orgullosa cómo varios vecinos la esperaban con un lote para ella remarcando con eso su legitimidad ya que hacía muchos años que la gente la conocía, incluso antes del asentamiento 9 de mayo. En la pelea por esos terrenos, Mary con unos vecinos habían decidido armar la "copa de leche" en su propia casa “...empezamos con la copa en el 2002, en la toma, eran todas carpas o casitas de nylon, mi casa era sólo un toldito, pero había muchos nenes y se necesitaba, poníamos todos un poquito".

La toma fue difícil, algunos vecinos recordaban que esos terrenos antes eran un basural, con perros y gatos muertos y repleto de ratas corriendo. En tanto Mary refería:

imaginate que cuando nosotros arrancamos con las tomas en el campito que era un campo de 13 manzanas nos rodearon más o menos 600 policías. Fue en ese momento que nos enteramos que el dueño del campo sería de un juez de Quilmes, que decían que era íntimo amigo del intendente Pereyra (intendente de Florencio Varela, perteneciente al PJ). Este juez era dueño de todo el predio, entonces se nos hizo muy difícil porque mandaban a reprimir pero también sabían que si llegaban a golpear a alguien iba a ser de grave costo político. Por esto cuando nos rodeaba la policía yo trataba de calmar la situación, de decirles a los vecinos que se calmaran que se quedaran tranquilos adentro de sus carpas. Y bueno, desde entonces nunca más nos movimos del predio. Además el campo ya estaba lleno de familias y cada familia ya había medido su porción de tierra para comenzar a construir. Fue así que comenzó a conformarse el barrio. Después con el tiempo fuimos organizándonos con los vecinos para ver a que puerta teníamos que ir a tocar, qué es lo que teníamos 
que hacer. Porque nosotros cero conocimientos de cuál era el paso siguiente a realizar. La mayoría de los que comenzamos con las tomas éramos hijos que estábamos viviendo con nuestros padres y teníamos familia, nietos que vivían con los abuelos o familiares que tenían familia y estaban viviendo en sus casas temporalmente, gente que alquilaba (España, 2013, p.3)

Mary recordaría la ayuda de los curas de la parroquia Santa Teresa, Enrique y Camilo, para evitar el desalojo, este vínculo seguiría por años y por ellos conocería a Tania unos años después. También otro de los participantes fue el "Nafta" Grieves quien era el referente de la organización social Martín Fierro. El "Nafta" era un personaje particular: usaba un sombrero “chamamecero" y había logrado su seudónimo cuando encabezó un reclamo en la Secretaría de Desarrollo Social de Florencio Varela por alimentos y para lograr tal fin roció su cuerpo con nafta, amenazando con prenderse fuego obteniendo así la respuesta al reclamo. En mis años en Varela nunca hablaría con él pero sí sería un referente del cual las personas del barrio me mencionarían, incluida Mary, como alguien de carácter complicado, con manejo discrecional de los recursos y utilización de la violencia como forma de manipulación política ${ }^{14}$.

Al año siguiente en el 2003, Mary se vinculó con el Centro de participación popular Padre Mugica recibiendo leche en polvo y otros alimentos. Esta organización había estado en la toma asesorando a los vecinos aunque Mary refiere no haberlos conocido en ese momento. Esta decisión de Mary profundizaría las diferencias con el "Nafta" con quien había coordinado al principio de la toma y dejarían de trabajar juntos.

Ya en el 2004 el Centro Mugica compró un terreno de 10 x 20 metros frente a lo de Mary para trasladar ahí la "copa de leche”, en "un ranchito de chapa cartón”. La casilla que conocí en el 2005 fue resultado de una donación europea al Centro Mugica, luego “...de que me hicieran un reportaje sobre el trabajo que hacíamos en el barrio me dijeron que íbamos a tener noticias de ellos y al poco tiempo mandaron la plata" agregaba Mary. La copa de leche recibió el nombre de Mirada al cielo; Mary y sus compañeras, además, cumplían un papel importante en la organización del asentamiento y en el diálogo con el municipio. Recuerdo que en ese tiempo no tenía lecturas sobre asentamientos ni toma de tierras, por lo cual me quedé fascinado cuando me relató “...organizamos tener un delegado por manzana. Y con el tiempo formamos una comisión que nos exigió el municipio. Entonces nos organizamos por medio de los votos

\footnotetext{
${ }^{14}$ Esta acusación (tanto al Nafta como a otros dirigentes) sobre supuestos robos de recursos entregados por el Estado para el barrio son recurrentes en la política popular y constituyen formas de dar sentido y legitimidad, tanto a organizaciones como a dirigentes.
} 
pusimos urnas en todas las esquinas y los vecinos votábamos dos delegados por manzana”. Mi primera impresión fue la de estar en presencia de una especie de organización parecida a los soviet me fascinaba la idea de los delegados por manzana, las comisiones y la asamblea, aunque me confundía que el mismo municipio les exigiera una comisión. Sólo años más tarde con varias lecturas como las Merklen (1997) y Cravino (2001) pude entender cómo las tomas de tierras seguían muchas veces la tradición de otras luchas como la fabril, la peronista e incluso la de barrios más antiguos (Maiorana, 2008).

La vinculación de Mary con el Centro Mugica potenció la organización de la "copa de leche" y del grupo que trabajaba allí. Mary comenzó a participar de los encuentros en la organización y en el 2006 cuando se constituyó el Encuentro Territorial para todos y todas, entre el Mugica y la parroquia Santa Teresa; Mary sería una de las participantes más frecuentes en las reuniones quincenales. En el proceso de negociación de los vecinos el municipio les solicitó que debían armar una comisión con una delegada a cargo por lo cual Mary se postuló junto a su grupo. Debieron enfrentar al "Nafta" Grieves y a su grupo en elecciones, donde habilitaron urnas supervisados por el municipio en cada esquina del asentamiento. Esta práctica novedosa para mí ya fue descripta por Merklen (1997) donde advierte sobre las consecuencias en la perdida de autonomía de las organizaciones y la división que les trae este tipo de competencia y la alianza con el sistema político. Esta misma situación la vería reflejada más adelante en la toma del 7 de abril. En tanto, en esa elección ante la inminente victoria de Mary las amenazas por parte del Nafta y su organización, Juventud de fierro no tardaron en llegar, incluido el intento de incendio de la "copa de leche" por medio de una molotov que fue sofocado rápidamente. El "trabajo social" de Mary, como ella solía nombrarlo, fue obteniendo su reconocimiento. María "la del barrio" como la apodaban en la salita aparecía pidiendo turnos para familias que ella consideraba de riesgo, incluso intentó armar una posta de salud en el propio asentamiento para que sea accesible la atención médica. Este acto generó resistencia en el personal de la salita, dado que no le veían el sentido, estando a cuatro cuadras de distancia. Estas rispideces no evitaron que el administrativo de la salita llamado Leo (militante del PJ) le ofreciera a Mary, aun sabiendo la pertenencia de ella al Centro Mugica, que se inscriba en el curso para ser "promotora de salud" e ingresar a la salita a cumplir ese rol. En el 2009 Mary ingresó a la salita con una beca.

A partir del trabajo cotidiano Mary fue constituyéndose en parte de una red informal de detección, atención de problemas y distribución de recursos que colaboraba conmigo. Mi tarea como trabajador social fue dependiendo cada vez más de esta red y orientándose para fortalecerla. Podría decir que se constituyó por mis propias necesidades de insertarme en el 
barrio pero al mismo tiempo ese espacio social tuvo sus mecanismos sociales de acogida a mi tarea profesional en un ida y vuelta constante. Esta reciprocidad fue parte de un largo encadenamiento de interdependencias sociales que incluyeron mis relaciones de dependencias como empleado y las tareas que me demandaba oficialmente mi rol como profesional del trabajo social contratado por el municipio (la política, las áreas de gestión municipal, la realización de informes, cartas de pobreza, certificados, etc.) y lo oficioso que era la otra cara de mi trabajo: las recorridas, las visitas, las charlas y los contactos personales que iba construyendo con la guía de Mary.

\section{De las reuniones de Red a Tania y los curas.}

El trabajo asistencial me permitió llegar a conocer a Mary y además recorrer todos los barrios y comunicarme con los gabinetes pedagógicos de las escuelas. Para la constitución de la Red contra la violencia familiar del barrio La Esmeralda fue determinante la posibilidad de incorporarme junto a mi compañera psicóloga del CAPS al programa Médicos Comunitarios ${ }^{15}$. Este programa posibilitó encarar el trabajo comunitario de manera organizada, supervisada por una tutora en terreno y con clases en la Facultad de Ciencias Médicas de la Universidad de La Plata impartidas por docentes con vasta experiencia en el trabajo de la atención primaria de la salud.

A fines del año 2005 convocamos a las instituciones a debatir acerca de los problemas de salud prioritarios. El objetivo de estas reuniones era generar y consolidar un espacio abierto de participación y articulación intersectorial donde pudieran ser abordadas de manera integral las problemáticas y los principales determinantes de la salud. Buscábamos en el marco del programa promover estrategias relacionadas con el cuidado y promoción de la salud y de esta forma modificar el paradigma de "curar la enfermedad y restaurar la salud". En esa convocatoria utilizamos la técnica de lluvia de ideas para facilitar la identificación y la priorización de los problemas de salud teniendo en cuenta la cantidad de población afectada por el problema; la evolución en el tiempo; los daños físicos, psicológicos o sociales que ocasionaba; las posibilidades que existen de realizar acciones de prevención; las posibilidades de solución que existen; y el interés de la comunidad frente al problema. La identificación del

\footnotetext{
${ }^{15}$ El Programa Médicos Comunitarios fue creado en la gestión de Ginés González García como Ministro de Salud de la Nación, con fondos provenientes del Banco Interamericano de Desarrollo, bajo la presidencia de Néstor Kirchner. Su objetivo general era "Fortalecer la estrategia de Atención Primaria de la Salud, como política de Estado, en los sistemas locales de salud" .http://www.msaludsgo.gov.ar/web2/?cargar=articulo\&id=126
} 
problema de abordaje fue "Bajo nivel en la detección y tratamiento específico de las mujeres que padecen situaciones de violencia familiar ${ }^{16 "}$.

Pese al objetivo de trabajar en base al consenso el desarrollo de las reuniones de salud iniciadas en el 2005-2006 fue teniendo cambios determinantes; las instituciones (la Sociedad de Fomento, el Centro de Jubilados) que participaron de las primeras reuniones se fueron retirando paulatinamente estas formaban parte de la UGL (Unidad de gestión local) de La Esmeralda y a partir de desacuerdos internos (que desconozco) dejaron ese espacio (el de la UGL) y luego el de las reuniones de salud. Estas instituciones no tenían desarrollo territorial extenso, salvo la parroquia de La Esmeralda que siguió participando del espacio. Por otro lado, se afirmó la presencia de los equipos de orientación de las escuelas y se sumaron referentes del asentamiento 9 de mayo y de la parroquia de Santa Teresa. Las primeras actividades se enfocaron en la violencia de género llegando a capacitarse a docentes de 2 escuelas y a residentes del CAPS por medio de una cartilla y la realización de una conferencia sobre el tema en el año 2007. Este espacio pasó a denominarse Red contra la violencia familiar. En el 2008 se estableció un encuentro quincenal donde se iban diagramando actividades de trabajo en conjunto. En el 2009 se sumaron nuevas instituciones con gran presencia de escuelas ${ }^{17}$, las dos parroquias de la zona, la "copa de leche" de Mary, el Centro de Discapacidad de Santa Rosa e incluso el FOL (Frente de Organizaciones en lucha).

Como se observa había una preponderancia de instituciones escolares. En las reuniones surgían

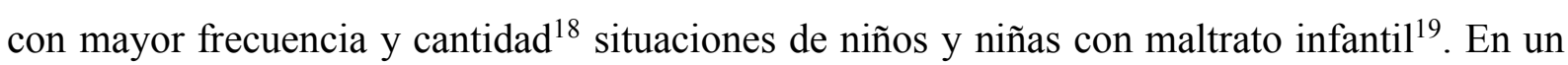

\footnotetext{
${ }^{16} \mathrm{La}$ red se conformó con el objetivo de abordar la violencia en el seno de las familias del barrio incluyendo a todos los integrantes y a todos los tipos de violencia por lo cual se definió como red contra la violencia familiar. La violencia de género se la incluía dentro de la familiar, aunque es bueno aclarar que en esos años al menos en nuestro trabajo todavía estábamos lejos de profundidad de los debates actuales sobre la violencia de género. Tomando la definición de la OMS, definíamos a la Violencia familiar como "Toda acción u omisión cometida en el seno de la familia hacia alguno de sus miembros, con característica de cronicidad y permanencia que menoscaba la vida o la integridad física o psicológica, o incluso la libertad de otro de sus miembros, que causa un serio daño al desarrollo de su personalidad".

${ }^{17}$ Escuela Primaria Básica № 20 (barrio La Esmeralda) Escuela Primaria Básica № 19 (barrio Santa Rosa) Escuela Primaria Básica $N^{\circ} 27$ (barrio Santa Teresa) Escuela Secundaria Básica N 55 (barrio Santa Rosa) Escuela Primaria Básica $\mathrm{N}^{\circ} 63$ (barrio Santa Rosa).

${ }^{18} \mathrm{~A}$ partir del trabajo en red se multiplicó la detección y el abordaje de situaciones de maltrato infantil desde psicología y servicio social. En el año 2009 se registraron desde servicio social 95 niños y niñas víctimas de maltrato, de los cuales sólo en seis había registro de maltrato por parte de los pediatras. Esta situación pude describirla en el trabajo final que hice para el curso de posgrado Médicos Comunitarios (Lozano;2009).

${ }^{19}$ Dentro de la violencia familiar tomábamos el maltrato infantil, al cual definíamos en las siguientes categorías:

Maltrato físico: Implica el uso de la fuerza física de parte de los padres o cuidadores. Es un daño físico intencional, no accidental

Maltrato emocional: Hostilidad verbal crónica en forma de insulto, burla o desprecio, crítica o amenaza de abandono, constante bloqueo de las iniciativas de interacciones infantiles (desde la evitación hasta el encierro) por parte de cualquier miembro adulto del grupo familiar o cuidadores.
} 
principio se daban intercambios informales de estos casos y luego se avanzó en trabajar con esta problemática desde "la red" en forma integral y planificada.

La Red funcionó quincenalmente y los lugares de encuentro fueron rotativos lo que permitió que todos los integrantes conozcan los diferentes barrios. Esta red fue coordinada y sostenida por el servicio de salud mental, residencia PRIM $^{20}$ y servicio social del CAPS, fue posible por las herramientas que tenemos como trabajadores sociales: por el manejo de grupo, por la posibilidad de trabajar en la interdisciplina y la intersectorialidad. La posibilidad del trabajo interdisciplinario fue algo que atravesó toda mi formación en la facultad. En diferentes materias se estudiaba la importancia de tener una mirada integral, histórica y critica sobre las situaciones que íbamos vivenciando en la práctica y la necesidad de abordar las situaciones problemáticas en coordinación con otras disciplinas y otros sectores. Constantemente revisitábamos autores como Morin (1998) quien advierte sobre las dificultades del "espíritu hiperdisciplinario" que atenta contra el abordaje de un mismo problema dado que se prioriza la disputa entre disciplinas frente a la búsqueda de conocimiento y respuestas; o Alicia Stolkiner (1999) sobre reconocer los limites disciplinares en las intervenciones y el doble carácter subjetivo y grupal de la interdisciplina. Con relación a la intersectorialidad en la facultad veíamos en varias materias La conferencia internacional sobre salud (1978) realizada en la ex URSS en la ciudad de Alma Ata. Estos principios suponían un cambio de paradigma en el abordaje de la salud enfatizando la importancia de los determinantes sociales (reconociendo implícitamente la desigualdad social) en la salud de las poblaciones y se definió a la estrategia de la Atención Primaria de Salud (APS) como la indicada para tratarlos. Dentro de la estrategia de la APS se contemplaba:

a) Integralidad.

b) Accesibilidad de la población a la atención de la salud.

c) Acción intersectorial entre las organizaciones de salud y otras agencias sociales y líderes comunitarios.

d) Organización y participación de la comunidad para asegurar el derecho a la salud y las estrategias de cuidado.

e) Cobertura universal en función de las necesidades de salud de la población.

Abuso sexual: Cualquier clase de contacto sexual con un niño menor de 18 años, por parte de un familiar/tutor/cuidador adulto, desde una posición de poder o autoridad sobre el niño.

${ }^{20}$ Programa de Residencias Integradas Multidisciplinarias. Es un programa del Ministerio de Salud de la provincia de Buenos Aires que se accede por un concurso. El CAPS era sede del mismo y yo actuaba como referente natural ad honoren de los colegas de los tres años que duraba la residencia, cargo que desempeñé del 2007 hasta noviembre de año 2014. 
En cada materia se debatía la mejor manera de fortalecer estos principios desde nuestra disciplina. Gran parte de nuestras actividades era el armado de grupos para debatir nuestras posturas y acordar estrategias.

En las reuniones de La Red, pude profundizar el trabajo de coordinación con referentes de la parroquia de Santa Teresa, una trabajadora social (Tania) y dos curas (Camilo y Enrique) quienes participaban de La Red. Este proceso fue relacional no el resultado de mis ideas y acciones individuales, sino de las tramas de relaciones donde esas ideas y acciones se fueron desplegando; no es casualidad, dada la trayectoria de la parroquia Santa Teresa, del propio Obispado de Quilmes y Tania como trabajadora social, que de coordinar situaciones concretas pasáramos a diseñar estrategias en conjunto. Las reuniones de La Red conformaban una agenda de trabajo para todos los integrantes pero fundamentalmente permitió esta coordinación con la parroquia, que se fue potenciando en el trabajo diario y luego tuvo un espacio propio. No tuve la misma acogida en los equipos de las escuelas pese a varias estrategias que desplegué para ello (socializar material de los asentamientos, del PROMEBA ${ }^{21}$, invitarlos a las reuniones con el Encuentro Territorial)

En los días previos a la toma del 7 de abril tuvimos la primera reunión anual de La Red. Como dije anteriormente, la modalidad era ir rotando por las sedes de cada institución u organización, para conocernos mejor, además luego de cada reunión había un responsable (generalmente era yo) de escribir la síntesis del encuentro y los acuerdos con la fecha de la próxima reunión y mandar el resumen por correo electrónico a todos los integrantes. Este tipo de modalidad fortaleció la Red y permitió trabajar temas a lo largo de diferentes reuniones.

En la reunión de Red previa a la toma del 7 de abril, anoté en mi cuaderno de campo:

Extracto del cuaderno de campo. Jueves 31 de marzo del 2011. Reunión de Red contra la violencia en la Escuela $\mathrm{N}^{\mathrm{o}} 27$ de Santa Teresa.

\footnotetext{
${ }^{21}$ El PROMEBA (Programa de Mejoramiento Barrial) surgió en 1997 por un crédito del BID (Banco Interamericano de Desarrollo) que contemplaba: mejoramiento urbano del barrio y de su equipamiento comunitario; regularización del dominio sobre la tierra; provisión de infraestructura básica domiciliaria y núcleo sanitario completo; mitigación de problemas ambientales; apoyo a procesos de organización barrial y autogestión comunitaria. La ejecución de los mismos se llevaba a cabo en forma descentralizada a nivel provincial, con coparticipación de las Municipalidades, organizaciones sociales y empresas de servicios. Al crédito del BID se le sumaba un aporte nacional $\mathrm{y}$ de las provincias que adhirieron al programa. Fuente http://www.politicaspublicas.uncu.edu.ar/articulos/index/las-politicas-urbanas-de-promeba-en-la-favorita-2004$\underline{2017}$
} 
"Nos reunimos en la Escuela 27 de Santa Teresa con las instituciones que conforman La red. Éramos cinco instituciones, faltaron dos escuelas y la parroquia de Santa Teresa que avisó. Por $1^{\circ}$ vez vino la Escuela 49 de Villa Argentina y el Centro para personas con discapacidad "Ruca Hueney”. La Escuela 49 comenta que desde hace dos años con las instituciones del barrio han luchado para frenar la entrega de las viviendas de Santa Teresa del Plan Federal de Viviendas ya que el estado municipal pensaba entregarlas sin la construcción de escuelas, centro de salud, líneas de colectivos, solo hay un jardín de infantes planeado. El antecedente que planteaban es el caso del PFV en Santa Rosa donde han sido otorgadas las viviendas a personas de todo Varela sin garantizarles las instituciones necesarias, lo que genero el colapso de las instituciones de barrios cercanos, la deserción de las escuelas y mala atención en salud. Se le pide a la escuela 49 que sistematicen y socialicen el proceso de lucha ya que el PFV se seguirá implementando en todo Varela y es interesante que los actores que se oponen a este tipo de implementación tengan material al respecto”.

La modalidad era que en cada reunión se hacía un breve repaso de la anterior y a partir de un temario se comenzaba a debatir cómo trabajar cada punto. Se abordaban diferentes temas (plan de viviendas, situaciones de abuso, abordajes institucionales, leyes) esto permitía un intercambio interesante y se iba construyendo un consenso a la hora de intervenir intersectorialmente. Algunos temas se profundizaban colectivamente, generalmente los que directamente atenían a las instituciones escolares que eran mayoría y otros se iban trabajando particularmente. Luego de acordar nuevas líneas de acción y asumir responsabilidades organizábamos el próximo encuentro. En cada encuentro se podían sumar nuevos integrantes y a la vez (en algunas ocasiones) dejaban de asistir algunas instituciones o lo hacían de forma esporádica. Asimismo, desde el Centro de Salud, la residencia PRIM y la parroquia Santa Teresa, con Tania como representante éramos los que siempre estábamos pugnando por sostener La Red. Eso llevó a profundizar nuestro vínculo y por su intermedio con los curas, a medida que iba pasando el tiempo, reuniones, charlas, debates, íbamos teniendo más confianza y comenzamos a reunirnos para pensar varias problemáticas de los asentamientos. 


\section{La risa de Tania y los asentamientos.}

Los encuentros con Tania se fueron sucediendo con una agenda en común: las situaciones de vulnerabilidad social, la violencia familiar y el apoyo a los asentamientos.

A Tania la conocí en el 2006 cuando se presentó en el Centro de Salud alegando que quería charlar sobre la situación de una chica con discapacidad que vivía en el asentamiento 9 de mayo. Tania estaba acompañada de un chico que refirió querer estudiar para ser cura. Ambos se presentaron como integrantes de la parroquia Santa Teresa, lo cual me alertó dado mis prejuicios hacia la Iglesia católica en general. Recuerdo que le dije seriamente que si eran del Opus Dei no tenían nada que hacer conmigo. Tania se rió espontánea y ruidosamente, esa sería una de sus características personales que aún en los momentos más difíciles no resignaría.

La risa de Tania me interpeló, sinceramente en esa época desconocía la tradición de la Iglesia católica en el trabajo territorial y menos aún la trayectoria del obispado de Quilmes. Para mí, la versión de la iglesia para los pobres se había terminado con la dictadura.

Tania trabajaba en la parroquia Santa Teresa comprendida en el obispado de Quilmes ${ }^{22}$.

Por mi parte, desconocía en esa época la tradición de ese obispado en su compromiso con los sectores populares y los derechos humanos y las experiencias en el territorio, por eso, cuando Tania se acercó al Centro de Salud me extrañó su presencia.

Tania, al igual que yo, no tendría más de 26 años en esa época. Antes de llegar a Varela vivía en Capital Federal donde trabajaba con los “sin techo", lo que la llevó a visualizar a la población en relación de prostitución y a acercarse a la cuestión de género, que posteriormente trabajaría en la casa de la mujer. Se había instalado en Florencio Varela en el 2006, su condición era de laica misionera voluntaria por lo cual tenía un contrato de voluntariado y percibía un dinero para sus gastos básicos. En ese año alquiló una vivienda del barrio Santa Teresa que abonaba con ese dinero, pero luego de un robo que sufrió se mudó a unas instalaciones de la parroquia en la antigua casa de los curas. Tania hacía "vida inserta ${ }^{23}$ " o sea que vivía y trabajaba en el mismo lugar donde la congregación tenía como objetivo "evangelizar ${ }^{24 "}$ para lo cual realizaba tareas pastorales y otras propias de su profesión.

\footnotetext{
${ }^{22}$ Este se creó en junio de 1976 por bula del Papa Paulo VI y comprende los partidos de Quilmes, Berazategui y Florencio Varela, anteriormente era parte de la diócesis de Avellaneda y se divide en cinco jurisdicciones internas y su sede metropolitana es la arquidiócesis de La Plata. El primer obispo de la diócesis, consagrado en 1976, fue Jorge Novak, hasta su fallecimiento en julio de 2001. En mayo de 2002 fue consagrado el obispo, Luis T. Stökler que terminó su misterio pastoral en diciembre del 2011 al renunciar por cumplir el límite de edad de 75 años, asumiendo Carlos José Tissera en su reemplazo

${ }^{23}$ Vida inserta es un término que se fue construyendo en los años '70 en la vida religiosa, luego del Concilio Vaticano II.

${ }^{24}$ Tania para explicarme en qué consistía la evangelización, me aportaría un texto de Víctor M. Martínez Morales (1988)
} 
Este voluntariado se desprendía del proyecto socio-pastoral de los misioneros clareteanos denominado de misión compartida ${ }^{25}$ : una experiencia entre religiosos y laicos dentro de un territorio y trabajando en función de problemas sociales. Tania, años más tarde, me explicaría y ampliaría en qué consistía este concepto para la congregación refiriendo que era una cosmovisión o paradigma en relación a como pensar y vivir la Iglesia. Esto implicaba vivir y construir otras maneras de organización, de celebración, de acción pastoral, de promoción humana, etc., siendo más que un trabajo en equipo o comunidad. Además Tania me aportó material bibliográfico para ampliar, aclarando que la idea de misión compartida se contraponía al clericalismo, tratando de combatir el autoritarismo y con la idea de poder trabajar con mayor participación en las decisiones. Ella destacaba que la misión compartida no era una estrategia sino un modo de ser, actuar y de vivir para promover una iglesia con participación de la comunidad con el objetivo de hacer una "familia de Dios" donde todas las personas que la integraran fueran cuidadas y respetadas en su forma de vivir. En este objetivo también contemplaban otras "formas de pensar y vivir".

Su congregación, los clareteanos, ya habían desarrollado la experiencia en otras provincias del país ${ }^{26}$ y tenían presencia en Florencio Varela desde hacía unos años atrás.

En este encuadre, Tania comenzó a ser parte de la parroquia Santa Teresa en el 2006, construyendo desde su experiencia personal, compartiendo espacios de oración-celebración, planificación de actividades-proyecto, acciones de promoción humana, recreativas, todo en coordinación con los curas Camilo y Enrique y ocupándose de uno de los proyectos de la parroquia, la casa de la mujer. Para Tania la Iglesia católica tenía una tradición de tareas y trabajo sobre la cuestión social, siendo las más conocidas las tareas asistenciales y de caridad por lo cual no era novedoso el trato de la cuestión social desde allí. Esto fue con el paso de los años motivando mi curiosidad por saber sobre el Obispado de Quilmes, donde encontré bibliografía que me permitió ampliar mi conocimiento. Autores como Maiorana (2008) en su interesante tesis sobre las tomas de tierra en Quilmes durante la década del 80, describe el rol protagónico del Obispado de Quilmes, con las comunidades cristianas barriales (CCB), inspiradas en las comunidades eclesiásticas de base (CEB) y de curas como Raúl Berardo ${ }^{27}$ en

\footnotetext{
${ }^{25}$ La misión, como razón de ser de la iglesia.

${ }^{26}$ Este voluntariado de la congregación clareteana comprendía lo que ellos definían como la provincia de San José del Sur (Chile, Argentina, Paraguay y Uruguay) donde se conformó un equipo que proponían experiencias de voluntarios a diferentes lugares.

${ }^{27}$ Raúl Berardo, un religioso salesiano, fue un reconocido cura obrero, militante social, con amplia y variada trayectoria de compromiso con los sectores populares. Tanto Pinedo (2018) como Maiorana (2008) le dedican en sus investigaciones un lugar importante. Hay una entrevista muy interesante, donde él mismo cuenta su experiencia
} 
el apoyo a las luchas populares y a las tomas de tierra en tanto Pinedo (2018) refiere la importancia para la acción colectiva de las clases populares del sur del gran Buenos Aires la creación de la diócesis de Quilmes en 1976 con el entrelazamiento entre clérigos y las manifestaciones de protesta social. En más de una ocasión Tania o los curas mencionaban la importancia del obispo Novak en el apoyo a las tomas de tierra, lo que manifestaban como una inspiración para ellos. El trabajo de Novak es reconocido por Santillán y Woods (2005) en las experiencias quilmeñas y Woods (2003) en un trabajo anterior refiere que a fines de la dictadura se empieza a destacar la actuación del Obispado de Quilmes en el campo social pero aún con un fuerte protagonismo de las CEB en apoyo a las tomas de tierra. Asimismo, como me contaría luego Mary, los curas habían participado de la toma del "9 de mayo" en conjunto con otros vecinos y referentes.

Tania era consciente de esta tradición del Obispado y de su propia congregación donde me aclaraba que varios integrantes eran de diferentes disciplinas, incluida la de Trabajo Social o la Sociología, con el ejemplo del cura español y sociólogo Daniel de la Sierra. Sin embargo era la primera vez que una colega trabajara en esa parroquia, por lo cual el rol lo fue construyendo de a poco. En ese proceso comenzó a revisar las prácticas sociales que tenía la parroquia Santa Teresa antes del 2006 y a ensayar otras propuestas.

Para ella la llegada a Varela implicó trabajar sobre una realidad mucho más compleja que la de Capital Federal, no solo porque las problemáticas eran diferentes sino también por el tema de los recursos: donde en Capital había más facilidad de obtenerlos y escaseaban en Varela. Por ello una de las primeras búsquedas fue la de financiamiento para desarrollar proyectos y articular con los claretianos para tener presencia como congregación en los asentamientos y enfocando principalmente el trabajo con las mujeres. En este camino, Tania principalmente y los curas, comenzaron a contactarse con los centros de salud y organizaciones que trabajaban en el territorio. Con los asentamientos, la parroquia Santa Teresa tenía el antecedente de haber intervenido en la conformación de los asentamientos de la zona en el año 2002. En esta misma línea decidieron desde la parroquia trabajar las problemáticas que surgían en los asentamientos $\mathbf{y}$ en desprenderse un poco de la tarea que venía realizando la parroquia de asegurar alimentos y ropa para la población. A su vez, pensar otras estrategias de intervención desde la Casa de la Mujer.

como cura obrero, su trabajo en el Ministerio de Bienestar social con el cura Múgica hasta las tomas de tierra en Quilmes durante los ochenta, en http://lobosuelto.com/entrevista-al-padre-raul-berardo-marzo-2003-quilmescolectivo-situaciones/ 
Esta casa tenía de referentes a las monjas de la Inmaculada Concepción, que ya veían las problemáticas de las mujeres en los asentamientos. Con la incorporación de Tania comenzaron $\mathrm{a}:$

“...pensar un espacio físico donde las mujeres salgan de sus casas, que se encuentren con otras y que participen de espacios recreativos un espacio en el cual ellas trabajen para sí mismas y no para otros. Es desde aquí, cuando comenzamos a acercarnos a las mujeres y su realidad y surgió el tema de la violencia. Comenzamos a preguntarnos si debíamos abordar la cuestión de la violencia o no; y decidimos que sí, que debíamos trabajar el tema de la violencia. Por lo cual nos contactamos con el MEDH (Movimiento Ecuménico por los Derechos Humanos), ellos tenían una experiencia interesante en la temática más bien realizando talleres de capacitación en la problemática. Trabajando con una dinámica en función de que las propias mujeres que atravesaron problemas de violencia acompañen a otras mujeres. Por lo cual realizaron varias capacitaciones acá en la Casa de la Mujer y empezamos a trabajar el tema de la violencia. En un principio hubo resistencia a trabajar el tema, las mujeres venían al espacio recreativo pero no se hablaba de la problemática de violencia. Pero con el tiempo pudimos desarrollar un espacio en el cual ellas se sintieran cómodas y pudieran hablar”. (España A., 2013, p.54).

La Casa de la Mujer de la parroquia Santa Teresa fue un recurso para muchas mujeres que veía en la salita y trabajar con Tania resultó ser un alivio para mí. Con ella, al contrario de muchas colegas con las cuales trabajaría y más que nada de la facultad, no hubo presentaciones de identidad política que tantas discusiones me traían en cambio cada uno fue conociendo el posicionamiento del otro a partir de la práctica. De los primeros encuentros formales y cuidadosos, pasamos al poco tiempo a la confianza, a la planificación de las intervenciones, a fortalecer la Red contra la violencia. Me presentó a los curas ${ }^{28}$ Camilo y Enrique quienes iban vestidos de jean, zapatillas, con sombreros para intentar cubrirse del sol en las tomas de tierras y en los barrios pobres de Varela donde no abundaban los árboles. Ambos reían, hacían chistes y renegaban del municipio, con el mismo coraje que tenían para enfrentar a la policía en un desalojo o a un marido violento en alguna intervención excepcional que le pedíamos con Tania

\footnotetext{
${ }^{28} \mathrm{~A}$ los presbíteros se los denomina generalmente como "curas" y para la iglesia católica comparten con los obispos el sacerdocio de los fieles para la celebración de los sacramentos, al respecto se puede consultar la página web del obispado de Quilmes http://www.obisquil.org.ar/index.php/15presbiteroshttp://www.obisquil.org.ar/index.php/15-presbiteros.
} 
cuando una mujer estaba en serio riesgo de ser lastimada. Luego pude conocer en las reuniones de La Red a Mariano quien trabajaba en la parroquia con ellos y también pertenecía a la congregación de los clareteanos.

Mariano, llamado en la parroquia como "hermano", era un misionero. Años más tarde me explicaría con mucha paciencia que había elegido esta opción, luego de cursar los seis años académicos en la congregación. En vez de ser sacerdote, diacono o incluso recluirse en un monasterio, Mariano había tomado los votos perpetuos (pobreza, castidad, obediencia) e iniciado en Florencio Varela su "experiencia comunitaria apostólica"29 que según la congregación clareteana es parte del trayecto formativo de los estudiantes y consiste en integrarse a una comunidad de misioneros claretianos y compartir con ellos su vida y misión diaria. En el 2011 tenía 32 años, y paulatinamente se fue involucrando en uno de los proyectos más importantes de los clareteanos de la parroquia Santa Teresa: el Encuentro Territorial junto al Centro Mugica. Esto implicó para Mariano participar de las reuniones y comenzar por el acompañamiento a unos vecinos que habían tomado una plaza en el barrio KM26, los cuales luego serían trasladados cerca del barrio Santa Teresa donde otro grupo de vecinos realizaría otra toma. Mariano también los acompañaría. Finalmente participaría en la segunda toma del 7 de abril y al año siguiente en la toma del barrio Luján donde sería amenazado varias veces. Mariano, de modales suaves y sonrisa franca, compartía la misma determinación que Tania, Camilo y Enrique.

Asimismo, Tania, con asombrosa pedagogía, fue explicándome la organización del obispado de Quilmes, las jerarquías, las diferentes pastorales y el "quién es quién” entre los curas de Varela.

En este mismo proceso, a partir de Mary y de ellos, conocí al referente del Centro de participación popular Padre Mugica el abogado Pedro Robles. Este Centro era un apoyo para las personas que tomaban tierras, para los inmigrantes y para los jóvenes que sufrían el hostigamiento de las fuerzas de seguridad. Con esta organización no establecí una coordinación al inicio de mi trabajo sino más bien que se fue construyendo a partir de espacios interinstitucionales de abordaje de problemáticas como violencia de género, migración y por situaciones en concreto donde la coordinación era fundamental para lograr resultados. Desde la parroquia coordinaban con el Centro Mugica y habían formado el Encuentro Territorial para todos y todas donde se reunían los delegados de numerosos asentamientos para aunar sus reclamos al municipio.

\footnotetext{
${ }^{29} \mathrm{Para}$ ampliar se puede consultar la pagina web https://www.claretianosdelsur.org/seminarista-claretiano-relatasu-experiencia-de-vida-y-mision-con-la-comunidad-de-montevideol
} 
Es interesante volver a remarcar que el trabajo de coordinación en temas atinentes a problemáticas estructurales ${ }^{30}$ solo pudo realizarse luego de años de trabajo, primero basado en lo asistencial, dado que estas organizaciones y la parroquia aceptaron y se acercaron a coordinar conmigo luego de que yo estuviera inserto en el barrio donde las personas que lo habitaban me reconocían como alguien confiable, alguien a quien poder referirle los problemas. Esta habilitación por parte de las personas del barrio generó nuestros primeros acercamientos. Al afianzarse los vínculos con la parroquia y el Centro Mugica, se posibilitó el trabajo de apoyo a los asentamientos y si bien en numerosas reuniones de La Red se propuso al resto de los integrantes (mayormente escuelas) sumarse a esa coordinación, no fue posible y manifestaron implícitamente seguir con la problemática de violencia de género y maltrato infantil por lo cual establecimos nuevos encuentros diferenciados. La coordinación con estas organizaciones implicó debates sobre las estrategias a llevar a cabo para lograr los reclamos de los asentamientos desde mi lugar como empleado de una agencia estatal, siendo estratégico y cuidadoso dado que el gobierno municipal era opositor a éstas.

A partir de los recorridos con Mary y el encuentro con Tania me fui insertando y circulando en redes institucionales e informales que trabajaban sobre la pobreza, pasando de una corte municipal a otra multi-institucional con fuerte presencia de la militancia cristiana.

Ellas me incluyeron en su red y yo las incluí en la mía, en la búsqueda de desafiar el espacio laboral propuesto por la institución que me contrató. Y, asimismo, no solo trabajé para la institución sino para esa nueva red generando que mi práctica profesional adquiera una inserción multidimensional y participativa en formas de trabajo sobre lo social ya instaladas en el territorio.

Las preguntas que atraviesan este proceso son ¿Por qué (Mary, Tania) lo hicieron? ¿Qué esperaban de mí? ¿Con qué finalmente se encontraron?

En la presente tesis iré respondiendo estas preguntas y surgirán de nuevo para interrogarme sobre la relación con otros referentes.

\section{Conclusión}

Trabajar en Varela fue para mí el descubrimiento de una trama social compleja donde fui insertándome a partir de mis tareas cotidianas y asistenciales. Un proceso de descubrimiento, de aprendizaje continuo y de nuevas búsquedas y rupturas producidas por el encuentro con los actores en el territorio.

\footnotetext{
${ }^{30}$ Considero que la disputa por el acceso al suelo urbano es una problemática de carácter estructural.
} 
Lo asistencial en el marco de mi trabajo para el municipio me generó debates y contradicciones. En efecto, existen en nuestra disciplina diferentes corrientes teóricas que advierten sobre las intervenciones inmediatistas, fragmentadas, ahistóricas que puede suponer el trabajo asistencial ligado a los recursos. Asimismo, se lo asocia a una pérdida de derechos, exclusivamente centrado en certificar la pobreza y agravado por un contexto de persistencia de las políticas sociales focalizadas. Desde muchos colegas hay una mirada peyorativa sobre la asistencia, como afirma Campana (2016), que impide avanzar en la discusión de la asistencia social como un derecho.

En mi experiencia, el trabajo asistencial fue la oportunidad de insertarme en el barrio y de tener legitimidad para otros tipos de intervenciones, donde la legitimidad lo es todo o casi todo. Efectivamente, para trabajar situaciones de violencia de género esa legitimidad me resultaba fundamental, dado que de alguna manera me protegía de eventuales agresiones de los victimarios y además contaba con una excusa para hacer el seguimiento a las mujeres en su domicilio, esgrimiendo que me acercaba por la encuesta de las chapas u otro recurso.

El trabajo asistencial requería tiempo, paciencia (en Desarrollo Social me habían advertido que si no cambiaba la letra de mis informes no me los recibirían por lo cual empecé a escribir en imprenta lo que me llevaba más tiempo), conocer cuáles eran los datos que podían ser usados como excusas para no brindar recursos por parte de Desarrollo Social y pensar estrategias al respecto. Por ejemplo, si ponía que vivía en el asentamiento sabía que no le darían materiales de construcción, por lo cual ponía direcciones de barrios cercanos o si había otro integrante adulto que tenía la tarjeta de alimentos (aunque fuera una familia numerosa sólo se permitía una por familia) "informaba” que la familia se había separado.

La realidad a la cual me enfrentaba diariamente era la de una población, como afirma Dulcich Piccolo (2008) sumergida en el fenómeno social del desempleo estructural y la descripción de las situaciones infrahumanas me llevaban a visualizar la gravedad del proceso de barbarización de la vida social (Dulcich Piccolo, 2008) y la permanencia en la cotidianeidad de la acumulación de desventajas (Bayón y Saraví; 2005). Cualquier recurso que yo pudiera gestionar para esa población era importante aunque fuera un kilo de leche en polvo o las semillas del INTA. Por lo tanto, la encuesta por las chapas o mercadería jamás me generó un dilema dado que ante la urgencia de la pobreza y estando en conocimiento de cómo funcionaban las políticas sociales sólo podía buscar la mejor estrategia para gestionar algún recurso a las familias del barrio, denunciando a la vez la precariedad y la focalización de esas políticas.

Por supuesto, este tipo de intervención generaba ciertas respuestas: "no pones filtro”, "le das a cualquiera”. Así solían decirme desde mis propios ámbitos institucionales (Desarrollo Social 
o algunos compañeros de salita), generó en mi la necesidad de profundizar mi trabajo con personas afines. Lo social como "materia opinable" y esas "intrusiones competitivas" al decir de Aquín N. y otros (2012) me generaba frustración y la mejor respuesta que encontré fue en el afuera institucional, en lo oficioso, junto a Mary, Tania y las escuelas. Para ello fue fundamental mis recorridos por el barrio que generaron la apertura de nuevos vínculos con actores del territorio y la construcción de nuevas problemáticas y la creación de redes de intervención. Pero además mi horizonte de intervención se guiaba por garantizar lo asistencial y a la vez la búsqueda de trascenderlo. Aquí la perspectiva crítica, a través de mi formación de grado me impulsaba (y a la vez por momentos me frustraba) a realizar un trabajo que apuntara a esas tareas transformadoras, a disputar con el Estado municipal dado que mi análisis (en ese momento) era que no garantizaban derechos básicos sino por el contrario reforzaban lazos clientelares en desmedro de ello. Eso no implicó que dejara de coordinar con los referentes del municipio, pero en mi agenda de trabajo quedaban rezagados. Igualmente mis convicciones ideológicas no se iban correspondiendo mecánicamente con la realidad así fui aprendiendo cómo y con quién trabajar superando prejuicios (Tania era parte de la Iglesia católica y Mary se definía evangelista). No obstante tuve una ruptura importante con mi trayectoria de grado y mi militancia, ya que la coordinación en mis prácticas era según la pertenencia partidaria a priori. A medida que me fui abriendo al territorio me encontré con una red de activismo social que provenía de una experiencia de formación distinta a la mía, esto me llevó un tiempo comprender. Aquí fueron fundamentales Tania y Mary, fueron ellas las que me enseñaron a trabajar en un territorio complejo donde la presencia de organizaciones piqueteras (MTR, FOL) y del peronismo no implicaba ser aliado de uno y enemigo del otro, pero sí que sólo la práctica cotidiana iba tejiendo las alianzas y el debate teórico, político, declamativo no tenía lugar o no tenía sentido porque los que nos unía era la forma de trabajar. Por eso comencé a cuestionarme que "hablar como los piqueteros" no necesariamente implicaba que estuviera siendo más comprometido con las luchas de las clases populares y por otro lado podía perjudicarme al permitir que se me cuestionara el rol técnico que de alguna manera solía ser un manto de "neutralidad", de donde podía justificar que ciertas tareas no me correspondían y que mi trabajo con uno u otro actor barrial no era algo político sino parte de una estrategia profesional. Revisar mis lenguajes y concepciones para ser más estratégico y menos ideológico no implicó perder el compromiso por los derechos y las intervenciones adecuadas a las distintas problemáticas que iban surgiendo. Por el contrario, la Red contra la violencia pudo sostenerse por este discurso e incluso desde el municipio reconocieron en varias oportunidades este trabajo lo cual me dio aire para profundizar el trabajo con Tania y los curas, Mary y el Centro Mugica. El trabajo en 
común con estas nuevas redes institucionales y barriales me llevó a los asentamientos y a ganar distancia y autonomía con respecto a mi empleador. Esto lo hice desde la construcción de un posicionamiento diferente frente a los debates más normativos y normativistas de los mandatos profesionales.

Todo esto fue para mí el inicio de Trabajar en Varela. 


\section{CAPITULO 2 \\ ¿SENDEROS QUE SE BIFURCAN? ENCRUCIJADAS DE UN TRABAJADOR SOCIAL COMO INVESTIGADOR}

\section{Introducción}

En el siguiente capítulo desarrollaré cuáles fueron mis recorridos teóricos y metodológicos en torno al estudio de las tomas de tierra y mi lugar como trabajador social. Cuando inicié mi investigación sobre una toma de tierras en Florencio Varela lo consideraba como un camino paralelo a mi quehacer profesional en el centro de salud. Sentía que mi trabajo me permitía acceder a la experiencia pero desde un lugar privilegiado e incómodo a la vez por no ser un investigador puro y ver como una amenaza mi pertenencia laboral. La amenaza que sentía era por considerar que esa pertenencia podía obturar mi reflexividad sobre los datos que recogiera en el campo dado que lo haría en el marco de mi trabajo, agravándose por lo que podía implicar para la gente del barrio la imagen de un trabajador social municipal en el contexto de una toma de tierras. La Etnografía resultaría fundamental para dialogar entre estos senderos de mi propia trayectoria en Varela.

\section{Senderos, encrucijadas y nuevas preguntas}

En enero del año 2011 cuando mi tutor de la maestría de Ciencias Sociales me hizo la propuesta de que escribiera un cuaderno de campo y acepté, sinceramente no sabía que en ese momento estaba consolidando un recorrido que había iniciado unos años atrás en la maestría de Ciencias Sociales y eligiendo una manera de aproximarme a responder las preguntas que atravesaron toda mi carrera y mis años en Varela; las preguntas sobre las condiciones de vida de la población y sobre el quehacer profesional. Una cita de Danani permite ampliar en qué sentido iban mis preguntas: “...el Trabajo Social está en condiciones de reinterpretar, comprender y explicar las intervenciones en cuanto construyen las condiciones de vida de los sectores subordinados" (2006: 8). En esta misma línea, la profesora Cazzaniga, nos refería que cada disciplina responde a una pregunta inicial, y en el trabajo social la pregunta es en relación a las condiciones de vida materiales y simbólicas de cierta población, grupo, familia o persona en determinado contexto. Mi tutor me sugirió qué tipo de registro tomar: "anota todo, tu trabajo, lo que pensás, lo que sentís, los análisis que haces, lo que te dice la gente, tus compañeros de trabajo...”. Esto sucedió unos meses antes de la toma lo cual me permitió que pudiera escribir sobre el proceso del 7 de abril desde el inicio y abarcar en esa escritura las condiciones de vida de la población de esos barrios y las respuestas desde las políticas sociales. 
Con mi tutor comencé a abrir el camino a nuevos interrogantes y a una nueva forma de trabajar: a no establecer grandes categorías que sin ningún tipo de mediación las utilizaba para explicarlo todo tal como eran mis producciones en la carrera de grado ${ }^{31}$. Además, y fundamentalmente, empecé a aceptar que mi trabajo podía ser objeto de análisis ya que desde allí se podían analizar desde las políticas públicas hasta las disputas territoriales. Sentirme con un respaldo para trabajar y para repensar mi práctica tal como lo había hecho en los talleres de la facultad y así salir de la rutinización de mi trabajo. Este proceso me permitió reconciliarme con la disciplina y me acercó a la Etnografía.

El obsequio del cuadernillo marcaría un antes y un después en mí. Luego de transitar la facultad jamás pensé que volvería a escribir un cuaderno de campo, de hecho en esos años (desde el 2004 al 2011) tampoco conocí a algún colega que lo hiciera. Recuerdo que la idea me entusiasmó, de alguna manera sentía que iba en el camino correcto hacia las respuestas que buscaba. Respuestas que habían comenzado con mi formación en la facultad y se habían profundizado con mi trabajo en Varela con las preguntas que me iban surgiendo diariamente. Estas búsquedas tuvieron un nuevo cauce teórico cuando comencé la Maestría en Ciencias Sociales y tuve como objetivo poder escribir una tesis sobre Florencio Varela relacionado al hábitat.

En este sentido, mi acercamiento a los referentes territoriales de los asentamientos fue paralelo al crecimiento de mi conocimiento teórico sobre el tema y de mi interés como incipiente cientista social. La toma de tierras que investigo en la presente tesis fue un disparador donde confluyeron, en dialogo y tensión, ambas trayectorias profesionales. Asimismo, la escritura de esta tesis permitió revisar y resumir las diferentes posiciones teóricas que fui tomando desde mis primeros años en Florencio Varela. En efecto el trabajo profesional me llevó a estudiar cada problema social en el cual intervenía: la desocupación, la pobreza, la violencia de género, la problemática del acceso a la vivienda, entre otros. En el trabajo cotidiano me iban surgiendo preguntas, a las cuales intentaba responder desde mi base teórica de la facultad y mis propias búsquedas.

Una de las preguntas fundamentales que me realicé, en un contexto de trabajo donde el área programática del CAPS contemplaba varios asentamientos, fue: ¿Por qué la gente toma tierras?

\footnotetext{
${ }^{31}$ En las producciones de mi carrera de grado, tengo varios trabajos donde con capitalismo, división del trabajo, neoliberalismo, explicaba desde un movimiento de desocupados hasta el posicionamiento profesional, sin ningún tipo de mediación conceptual.
} 
Ya cursando la maestría de Ciencias sociales pude acceder a uno de los trabajos que me aportaron en principio algunas respuestas: Reese en una entrevista ${ }^{32}$ en Pagina 12, refiere que el aumento indiscriminado de los precios del suelo urbano por el funcionamiento especulativo del mercado inmobiliario hace inaccesible al trabajador la compra de un lote o vivienda, siendo imposible que las políticas actuales del Estado compensen tales efectos. Otra autora que sería fundamental en cada lectura sobre los asentamientos fue Cristina Cravino quien en un trabajo que escribe en el 2001 reflexiona sobre por qué los sectores populares (excluidos de la posibilidad de acceder a la tierra urbana por el mercado o por el Estado) ocupan tierras baldías -fiscales o privadas- lo que muestra las contradicciones de la urbanización capitalista, y del Estado de Bienestar que tendió a extender los derechos sociales, sin garantizar su acceso.

Estas respuestas si bien brindaban elementos para el análisis global del contexto, no me permitían entender y profundizar sobre los procesos, los conflictos y las estrategias que se desarrollaban. A su vez la primer pregunta que realicé me conducía a respuestas economicistas y causales, las cuales no se condecían con las múltiples estrategias que había observado desarrollar por las familias que tenían problemas habitacionales; donde la toma de tierras no era una primera opción y la mayoría de las veces no era una posibilidad que analizaran. Esto lo había vivido en esos años que llevaba en el centro de salud, visitando y haciendo informes sociales requiriendo recursos para la refacción de viviendas en situación de precariedad ${ }^{33}$.

\section{Etnografías sobre sectores populares y trabajo social: un encuentro posible.}

En el año 2011 decidí profundizar mi conocimiento sobre la Etnografía y me inscribí en un seminario que dictaba Virginia Manzano ${ }^{34}$ en la facultad. Volver a leer Etnografía me llevó a revisitar las materias que había cursado en la carrera de grado donde teníamos una breve aproximación teórica ${ }^{35}$ a la etnografía y el desarrollo de una sus herramientas más importantes. Sin embargo, veíamos la teoría en las materias de Antropología Social y el cuaderno de campo lo escribíamos en las materias de Trabajo Social, de primero a quinto año, el cual supervisábamos con los docentes de los talleres de las materias de trabajo social. La finalidad

\footnotetext{
${ }^{32}$ Reese E. (octubre 2014) "La informalidad agrava la pobreza”. Página 12.

${ }^{33}$ Por precariedad se entendía viviendas con indicadores de NBI y familias en situación de pobreza. Los informes sociales se presentaban en la Secretaría de Desarrollo Social, donde las personas debían concurrir y allí de acuerdo a diferentes criterios (estos se presentaban como ilegibles, dado que familias en la misma situación podían o no recibir algo) le otorgaban materiales, generalmente chapas y colchones.

${ }^{34}$ Dra. de la Universidad de Buenos Aires (orientación Antropología Social). Becaria Posdoctoral del CONICET. Miembro de los proyectos FI 041 -UBACyT- y PIP 5858 -CONICET-, y del programa de estudios sobre protesta y resistencia social. Ambos, proyectos y programa, bajo la dirección de la Dra. Mabel Grimberg. Sección de Antropología Social, Facultad de Filosofía y Letras, UBA.

${ }^{35}$ En la materia Antropología Social veíamos algunos textos claves como los capítulos de Rosana Guber en "El salvaje metropolitano" y el de Clifford Geertz sobre descripción densa
} 
de la escritura en la carrera de grado tenía que ver con analizar y describir la realidad en la cual interveníamos, pero no para una investigación académica sino principalmente para reflexionar sobre nuestra propia intervención. A la hora de explicar los elementos que me surgían de la realidad no elaboraba categorías desde el encuentro con el nativo ${ }^{36}$, desde sus significaciones, sino que reforzaba la utilización de grandes categorías (capitalismo, neoliberalismo, políticas sociales, entre otras) para explicarlo todo. En palabras de Guber (2004), no sometía a los conceptos que elaboran otras disciplinas sociales a la diversidad de la experiencia humana, a nuestra propia práctica. Otra diferencia es que tampoco me consideraba como parte del propio análisis hecho fundamental para esta autora:

...en suma, el investigador no es menos "ser social" que aquellos a quienes investiga, por el hecho de aparecer individualizado en la etnografía e individualmente en el campo (...) queremos analizar entonces el capital más valioso del conocimiento antropológico (y, probablemente, del de otras disciplinas), la principal herramienta de trabajo de los investigadores sociales: nuestra propia persona. (Guber, 2004:14 y 15).

El cambio de enfoque y leer textos que me permitían entender la realidad varelense me impactó. La lectura de material etnográfico y sociológico sobre procesos como las tomas de tierras, los piqueteros, fue determinante. Aún recuerdo la fascinación que me produjo los textos de Cravino al analizar los asentamientos y los de Quirós sobre la trama social, respondiendo ambos a preguntas que durante años no podía responderme. Curiosamente desde estas disciplinas, a través de Virginia Manzano en el seminario que curse con ella y de mi tutor, me alentaron a potenciar mi lugar como trabajador social en el propio proceso de investigación, desafiándome a dialogar desde la disciplina con el corpus teórico de la Etnografía y la textualización de la pesquisa en el campo. Me volví, superando mis resabios positivistas, parte del propio proceso de investigación al comprender que este se hace desde la perspectiva de la experiencia de mi hacer profesional como trabajador social en mi ámbito laboral teniendo un doble eje de la perspectiva de investigación: la etnografía sobre sectores populares y la reflexión crítica en el campo del trabajo social.

Otro impulso fundamental para que realizara una etnografía provino de la visita de Julieta Quirós al Centro de Salud La Esmeralda en el marco de su trabajo de investigación que

\footnotetext{
${ }^{36}$ Nativo se define por las personas que serán objeto de la pesquisa, es un concepto traído desde la Antropología y fundamentalmente de Bronislaw Malinowski.
} 
terminaría con la publicación de "El por qué de los que van”. En esa ocasión Julieta acompañaba a una mujer víctima de violencia de género que quería consultarme. Recuerdo que Julieta se presentó y me comentó que escribía etnografía y que ya tenía algo publicado. También me informó que cursaba en una Universidad de Brasil lo cual me sorprendió (una antropóloga argentina cursando en Brasil pero escribiendo sobre Varela) y en una charla posterior, me obsequió el libro anterior de su autoría "Cruzando la Sarmiento"37. La lectura de este libro me llevo a entender por qué los integrantes del comedor piquetero ${ }^{38}$ donde yo concurría como voluntario unos años atrás en el barrio de Los Hornos de la ciudad de La Plata, me decían "estoy con los piqueteros". Esta revelación fue fundamental para comenzar a considerar de mi parte la importancia de la Etnografía y la construcción conceptual partiendo de las categorías que construyen los propios sujetos investigados.

Con estos aportes y a partir del seminario de Virginia Manzano, amplíe mis bases teóricas y conocí nueva bibliografía que me llevo a interrogarme sobre los supuestos que tenía acerca de la realidad. Tomando a Thompson (1995), invertí la pregunta inicial: ¿Por qué la gente toma tierras? y la reformulé ¿Qué hace la gente cuando no tiene casa donde vivir? ¿Toda persona toma tierras? Las respuestas me fueron naciendo al recordar las palabras de cada persona a la cual había entrevistado en la salita desde que comencé a trabajar; donde se acercaban a relatarme su situación y a pedir la intervención del Estado municipal. De estos relatos surgía que las personas cuando no tienen casa donde vivir alquilan, viven en lo de un familiar hacinándose, se construyen una pieza precaria en el fondo, en el techo, viven en la calle, toman una casa abandonada, se mudan numerosas veces, reclaman al Estado, a la Iglesia, a los piqueteros. Para Thompson (1995) su objeto de estudio, los motines del hambre, no se podían explicar por causa - efecto, no bastaban las explicaciones economicistas. Este autor entiende que las motivaciones de la multitud para realizar los motines no pueden reducirse solo a causas económicas (la miseria y/o pobreza que genera hambre) lo que no quiere decir que los amotinados no tuvieran hambre, pero eso solo, no basta para explicar que realicen un motín y en su estudio desarrolla ejemplos de poblaciones enteras que literalmente murieron de hambre

\footnotetext{
${ }^{37}$ Otra de las cosas que me sorprendieron de Julieta y de varios investigadores fue la generosidad y paciencia que tuvieron conmigo, aportando material, ideas, leyendo y sugiriendo.

${ }^{38}$ Por piquetero se entiende a los integrantes de los Movimientos de trabajadores desocupados surgidos a mediados de la década de los '90 y consolidados en el 2001.Parten de la metodología de protesta, reclamando trabajo y ayuda social, consiste en el corte total o parcial de rutas o calles importantes de comunicación. El término "piquete" a su vez proviene de una modalidad del movimiento obrero en contextos de huelga que para evitar el ingreso de trabajadores no adheridos al paro a la fábrica, impedían su paso. En Argentina, según Manzano (2008) el piquete se transformó en la forma apropiada para demandar el compromiso del Estado sobre los problemas de trabajo o, más específicamente, sobre el problema de la desocupación siendo fundacionales los realizados en la provincia de Neuquén y Jujuy luego de la privatización de YPF y el despido de miles de trabajadores entre los años 1996 y 1997.
} 
sin realizar medidas de este tipo y da otros ejemplos donde se recurre a otras medidas desde la venta de niños a la solidaridad entre las personas. Stratta y Barrera (2009) retoman a este autor y agregan en su análisis que el empobrecimiento de la población no es suficiente para explicar los procesos de acción colectiva porque eso nada nos dice acerca de cómo su conducta es modificada por la costumbre, la cultura y la razón, como afirma Thompson (1995).

Desde esta lectura y con la supervisión de mi tutor seguí con la escritura del cuaderno de campo, detallando diariamente mi experiencia y reflexiones en torno a mi trabajo y mis visitas frecuentes al incipiente asentamiento. Desde este ejercicio comencé a realizarme otras preguntas, recordando la cita que hace Manzano (2010) sobre Peirano (2004), quien afirma que el proceso de descubrimiento antropológico resulta de un diálogo comparativo entre la teoría acumulada de la disciplina y la observación etnográfica que presenta nuevos interrogantes y nos lleva a desafíos para ser entendidos e interpretados. Hasta ese momento la teoría acumulada de la cual disponía desde mi proceso de formación en la facultad de Trabajo Social de la UNLP 39 se relacionaba con enfoques que se centran en actores sociales colectivos presentados como homogéneos e incluso idealizados al calor de las jornadas del $2001^{40}$. Uno de los ejemplos

\footnotetext{
${ }^{39} \mathrm{Al}$ hablar del proceso de formación de la facultad me refiero sólo a mi propio proceso, sin intenciones de generalizar.

${ }^{40} \mathrm{El} 19$ y 20 de diciembre del 2001 marcaron el final del mandato del presidente Fernando De la Rúa, cuando amplios sectores de la población resistieron el estado de sitio decretado para frenar las protestas por las medidas neoliberales del gobierno. La confluencia en asambleas barriales de sectores llamados clases medias con la de los piqueteros fue para muchos autores y partidos de izquierda (el Partido Comunista Revolucionario referirá a estos acontecimientos como el argentinazo y analizará los factores que indicaban para ellos un momento pre revolucionario) el surgimiento de un movimiento revolucionario, Retamozo (2006) señala que "La hermenéutica del 19 y 20 de diciembre se expresa en las dispares interpretaciones de los partidos de izquierda, para algunos significó la apertura del proceso revolucionario (MST, POb) para otros un estallido revolucionario (PTS), para algunos una rebelión espontánea, para otros una insurrección popular, para otros una pueblada, etc.". Por otro lado, hay diferentes interpretaciones sobre el rol del PJ en los saqueos a comercios con el fin de desestabilizar al gobierno radical. Una cronología de los hechos: El 13 de diciembre, las tres centrales sindicales convocan a una huelga general contra la política económica y social del gobierno de De la Rúa y contra la aplicación del llamado "corralito" (prohibición de extraer dinero en efectivo de los bancos en sumas superiores a 250 pesos o dólares por semana realizado el 2/12/2001 por el Ministro Domingo Cavallo) y otras medidas económicas neoliberales como recortes presupuestarios a la educación, la salud y por el deterioro de la calidad de vida. El paro tiene un masivo acatamiento. Estos acontecimientos comienzan a anticipar los sucesos de la semana siguiente. El 19 de Diciembre, en Buenos Aires y muchas ciudades, miles de personas de los sectores más empobrecidos se concentran frente a los supermercados para exigir comida, lo que deriva en saqueos masivos muchos de los cuales (sobre todo en las provincias gobernadas por el Partido Justicialista) no fueron evitados, sino que queda la sospecha de que por el contrario muchas veces fueron implícitamente incentivados, Muñoz (2009) señala al respecto "Entre el 13 y el 22 de ese mes, se registraron 584 ataques a diferentes comercios y supermercados (Iñigo Carrera y Cotarello 2003). Para Auyero $(2006,2007)$ los saqueos fueron activados por redes en donde participaron los referentes locales de los partidos políticos opositores, que en muchos casos, ofrecieron recursos para la organización e instigaron a los vecinos de zonas pobres a saquear pequeños comercios y mercados". Por su parte, algunos dueños de comercios y custodios privados de los grandes supermercados atacan con armas a los "saqueadores" y se producen los primeros muertos y heridos. El 14 de diciembre, en La Plata, trabajadores estatales y docentes se movilizan he intentan tomar la legislatura enfrentándose con la policía (Iñigo Carrera;2003) y hay decenas de heridos con balas de goma. En Córdoba se movilizan trabajadores municipales, y se producen duros enfrentamientos. Hechos similares se produjeron en la provincia de Neuquén. Al anochecer, De La Rúa habla por televisión y anuncia el estado de sitio "para defender vidas y bienes". Es el detonante: sin ninguna convocatoria en las horas siguientes
} 
recurrentes era la literatura sobre el fenómeno piquetero que provenía del Colectivo Situaciones $(2003,2004)$ y de James Petras (2002). Esas lecturas, junto a la de otros autores, ${ }^{41}$ presentaban un horizonte optimista donde el cambio social era posible. Uno de los ejemplos más mencionados era el Movimiento de Trabajadores Desocupados ${ }^{42}$ de San Francisco Solano donde la organización se basaba en la horizontalidad, participación, democracia directa y autonomía de partidos políticos y organizaciones sindicales. Bidaseca (2004). Se hablaba de una nueva forma de poder popular y de nuevas identidades tales como la de piquetero.

Esta matriz conceptual de mis últimos años de la facultad (2002-2004) era la que en el ejercicio profesional me guiaba al analizar cada fenómeno social. En vez de generar preguntas abiertas que dieran cuenta de los procesos, analizaba mecánicamente la información, intentando que coincidiera con las categorías que traía de mi formación de grado, por eso en ese momento vinculaba por ejemplo al asentamiento como resultado de una disrupción sistémica ${ }^{43}$ desconociendo la bibliografía sobre la temática.

Avanzando en el conocimiento de la literatura sobre la toma de tierras en zonas marginales me resultó un aporte valioso lo señalado por Wacquant (2007) quien refiere que la marginalidad urbana ha adoptado formas específicas de acuerdo a los modos en que se han vinculado Estado, clases y espacio en la historia de diferentes sociedades.

Esta triada conceptual me permitió tener una mirada más amplia, ya que la pregunta sobre los procesos de ocupación de tierras en zonas marginales y urbanas abría el interrogante sobre la relación entre el vínculo del Estado y sus agencias ${ }^{44}$ con las distintas modalidades de estrategias

miles de personas salen a la calle en los barrios de la Capital Federal y el Gran Buenos Aires a realizar un "cacerolazo". Espontáneamente las columnas de los barrios comienzan a marchar hacia Plaza de Mayo. Después de la medianoche, comienza la represión y es asesinado uno de los manifestantes. En la madrugada se conoce la renuncia del ministro de economía, Domingo Cavallo. Hugo Moyano, dirigente de la CGT, declara que "La mejor ayuda que podemos dar es mantener la pasividad". Similar actitud asumen otras direcciones. Al día siguiente (20/12) estaba convocada desde varios días atrás una concentración frente al Parlamento por parte de la CTA, el Movimiento Piquetero y los Partidos de Izquierda. La CTA y la CCC acatan el estado de sitio y levantan el llamado. Pero hubo sectores que se sumaron al movimiento de masas y no lo acataron. Es el caso de SUTEBA, secciónales de ATE, sectores de Docentes Universitarios, el Sindicato de Mensajeros y Cadetes, organizaciones piqueteras (MTR, MIJP, MTD Aníbal Verón y otros grupos menores), y la Izquierda (IU, PO, PTS, FOS, CS, MAS, etc.) Luego de un fracasado intento de formar un gobierno de unidad nacional con el peronismo, De la Rúa presenta su renuncia y a las 19:50 horas es retirado en helicóptero de la Casa de Gobierno. Producto de estas dos jornadas hubo más de 30 muertos y cientos de heridos por la represión policial y parapolicial.

${ }^{41}$ Zibechi. “Maxi y Darío: Dignidad Piquetera” Boletín de La Brecha. 2003

${ }^{42}$ En el libro realizado por el MTD Aníbal Verón se desarrolla estas características. "Darío y Maxi, dignidad piquetera. El gobierno de Duhalde y la planificación criminal de la masacre del 26 de junio en Avellaneda" Ed. 26 de junio. Junio 2003

${ }^{43}$ En el Seminario de tesis de la FAHCE escribí en el 2007 un trabajo titulado así "toma de tierras en contexto de disrupción sistémica" donde analizaba causalmente la toma de tierra con las jornadas del 2001.

${ }^{44}$ Por agencia estatal entiendo a las agencias de gobierno, a las diferentes instituciones que lo nuclean en las funciones que dependen del ejecutivo, como ser la Secretaría de Salud, Desarrollo Social, Desarrollo Laboral, de Deportes, también incluyo a la Policía. 
habitacionales desplegadas por los sectores populares para operar en el territorio, en este caso a través de la ocupación de un espacio desocupado y disputarlo ${ }^{45}$.

Unas de mis preocupaciones centrales al inicio de este proceso era mi lugar como trabajador social, creyendo que de alguna manera obturaba el dato que recogía en la pesquisa, aunque la textualización de la misma incluía mis propias reflexiones críticas sobre el campo disciplinar. Mis temores eran sobre la potencialidad de esos datos, siendo yo un empleado de una agencia del Estado consideraba que esa pertenencia podía obstaculizar el relato de los nativos y mi propia mirada. Me sentía en un lugar incómodo y privilegiado a la vez. Para superar esto fue fundamental el aporte que recibí en los seminarios de la maestría y al consultar a diversos autores $^{46}$. Pude concluir que el trabajo de campo se hace desde algún lugar y eso era algo que me pasaba a mí o a cualquier investigador. Ingresamos desde algún lugar y hay que reflexionar acerca de lo que nos da y nos quita. No es tanto el lugar desde el cual se ingresa al campo lo que caracteriza a la Etnografía (en última instancia, grandes etnógrafos fueron empleados de la administración colonial) sino el tiempo de permanencia en el campo y un enfoque que busca restituir un punto de vista del otro. Ambas búsquedas posibilitan la producción de relaciones más o menos duraderas en el campo y la producción de datos muy densos (Geertz), ricos, profundos, con matices, siendo importante dos cuestiones clave: por un lado, explicitar las condiciones (lugar, rol, situación, tiempo de permanencia, etc.) en la que se produjeron los datos (cuaderno de campo, observaciones, entrevistas, etc.); y por el otro, reflexionar sobre mi lugar en el campo, lo que mi rol como trabajador social de la municipalidad habilitó pero también lo que condicionó, lo que inhabilitó, etc.

Comprendí finalmente que esa doble tensión conceptual y teórica, era sobre la que me apoyaba para hacer la investigación y producir conocimiento desde mi experiencia. Dicha doble tensión al mismo tiempo se replica en la metodología y en la textualización que desarrollé en mi trabajo. Finalmente, de los autores que realizan etnografía y del corpus teórico de nuestra profesión, pude extraer las enseñanzas que me guiaron en el antes y después de la experiencia en el 7 de abril:

- La observación participante, Guber (2004) la define como el medio ideal para examinar teorías en contextos reales concretos, siendo un proceso complejo de interacción con los agentes sociales.

\footnotetext{
${ }^{45}$ En el caso que nos ocupa no había constancia de la situación legal de los terrenos, esto fue parte de la disputa. ${ }^{46}$ Además de mi director de tesis, el intercambio con Julieta Quirós, Ramiro Segura y Virginia Manzano, resultaron determinantes.
} 
- La entrevista es en general informal y no directiva, y articula con la observación participante, a excepción de la entrevista en profundidad que le realicé a uno de los referentes, pero en el marco del acuerdo que establecimos para vincularnos ${ }^{47}$.

- Los registros y grabaciones, atravesados por los hábitos de la profesión y sus dilemas éticotécnicos con los hábitos de la gente con sus propias tensiones y dilemas vitales.

- Mi cuaderno de campo, elaborado por estas premisas y con el antecedente de la carrera de grado, lo supervisé con mi tutor y fue presentado en un seminario de abordajes etnográficos, donde fue enriquecido para mí posterior análisis. ${ }^{48}$

Por lo tanto, utilicé la Etnografía para visualizar mi experiencia como trabajador social en la trama social del proceso de toma de tierra, con el tejido de relaciones en el contexto barrial donde se constituyen estos actores. Para ello, analicé mi cuaderno de campo escrito en el marco de mis tareas en el Servicio Social del CAPS (Centro de Atención Primaria en Salud) La Esmeralda dependiente a la Secretaría de Salud y Desarrollo Social del municipio de Florencio Varela.

Entendiendo que la Etnografía no es sólo un enfoque metodológico, ni una mera recolección de datos. En efecto, es un modo de conocimiento propio de la Antropología que ha sido tomado por otras disciplinas y requiere que el investigador tenga una instancia prolongada en el universo social a estudiar formulando sus preguntas de investigación a partir del punto de vista de los nativos. Quirós (2011) advierte que la teoría etnográfica no es puramente antropológica ni puramente nativa sino que es aquello que el etnógrafo produce en el encuentro de una cosa con otra. Así se puede generar un conocimiento modelado por la relación nosotros/otros, de esta forma deconstruyendo la realidad e interpretando los significados que las personas le dan a sus prácticas. "En este tipo de obra se presenta al grupo, sociedad o individuo en cuestión en el fluir de su vida cotidiana, en la organización de sus ceremonias y en el cumplimiento de su ciclo vital" (2011:26). En el caso que estudié esta afirmación merece una aclaración: las personas que estaban tomando las tierras lo hacían en un modo excepcional de ese fluir, no tenía que ver con lo que había sido su cotidiano (lo que históricamente hacían desde la

\footnotetext{
${ }^{47}$ Con Emilio Saldivar, referente del asentamiento, antes de la toma del 2011, nos encontramos varias veces en el centro de salud, donde me comento que había sido militante del Movimiento Teresa Rodríguez y referente de la toma del 2002, en el "9 de mayo". En ese marco, le manifesté mi interés para que me relate su experiencia de vida, constantemente él me recordaba esa entrevista pendiente, incluso me invito a la nueva toma para que le haga la entrevista allí. Finalmente, luego de que finalizara el proceso del asentamiento, le realice en su casa la entrevista en profundidad.

${ }^{48}$ En este seminario, dictado por Virginia Manzano y Fernández Álvarez (reconocidas autoras en el campo de la Etnografía y Sociología), presenté a instancias de las profesoras, mi cuaderno de campo como objeto de debate en una de las clases, por lo cual desde el grupo (conformado por otros estudiantes de maestría con experiencia en investigación) me señalaron aspectos para desarrollar, aclarar, profundizar y aportaron debates teóricos para la interpretación del mismo.
} 
organización familiar, llevar a los niños a la escuela, etc.) y lo que sucedió en esos meses, más allá de cierta organización colectiva en algunos temas que podía generar cierta idea de rutina (cocinar, buscar leña, agua, asambleas) fue un cotidiano atravesado por la incertidumbre y lo inesperado. Además creo que mi presencia casi cotidiana y la de otras personas ajenas marcaba la excepcionalidad de la experiencia que estaban transitando.

Lo que me permitió la Etnografía fue un escrutinio permanente del dato producido por esas relaciones sociales dado que no hay una instancia separada de recolección de datos y posterior análisis al contrario existe un proceso de textualización permanente en palabras de Manzano (2011).

Otro aporte de la Etnografía es que se puede visualizar a la sociedad como un campo de fuerzas, no solo como relaciones interpersonales sino que se puede analizar cómo surgen las fuerzas colectivas, considerando central ese fluir de la vida diaria de los sujetos (Quirós, 2011). Es en ese fluir en el cual los sujetos inscriben sus prácticas colectivas. Aquí fue interesante el proceso del asentamiento ya que esa fuerza colectiva se fue constituyendo día a día, no estaba dada ni siquiera al inicio.

Estas autoras señalan la necesidad de salir de esquemas dicotómicos y/o binarios como los desarrollados por los primeros teóricos de la acción colectiva (Touraine, 1987) y de la política en los sectores populares (Auyero, 2001) donde se los homogeniza en identidades estancas y se idealiza su práctica por considerarlas propositivas, de buena política a diferencia de las estrategias de supervivencia y de la mala política asociada al clientelismo político (Manzano, 2011; Ferraudi Curto, 2014). En el desarrollo y la conclusión de esta tesis discutiré sobre este aspecto. El campo de fuerza, concepto recuperado por Manzano (2008) de autores como Thompson (1995), Roseberry (1994) y Grimberg (1997) permite captar las tensiones, las correlaciones de fuerza cambiantes, los condicionamientos recíprocos entre las políticas estatales y las modalidades de acción y ponderando el peso de las experiencias históricas en la formación de espacios de disputa social y política. Manzano (2008) reconstruye desde el concepto de campo de fuerza múltiples formas de disputar y múltiples formas de dominación, lo cual nos permite entender las maneras de “...disputar, demandar, negociar y concertar con autoridades gubernamentales" (Manzano, 2008: 29). El proceso del 7 de abril representa un claro ejemplo de esto. En la búsqueda de la sensibilidad etnográfica (Peirano, 2004) es fundamental la lectura de otras etnografías y compararlas en los términos que plantea Ferraudi Curto (2014) quien toma a Geertz (2001) para decir que hacemos interpretaciones de interpretaciones y esto puede incluir a "villeros", "dirigentes", "piqueteros" y "etnógrafos”. Para esta autora, la comparación de etnografías ya es parte de la propia experiencia del trabajo 
de campo, y en este ejercicio de la comparación con otras descripciones de la cultura y otras etnografías de otros investigadores se puede ver la validez del trabajo realizado (Guber, 2004).

\section{Conclusión}

Como desarrollé a lo largo de este capítulo, puedo afirmar que la Etnografía me permitió dialogar entre dos senderos que yo consideraba separados: la intervención profesional y la investigación académica. Y no sólo ello, en este rodeo que fui dando desde mis lecturas en la maestría de ciencias sociales, retomé uno de los mejores ejercicios de la carrera de grado, escribir un cuaderno de campo. Esta escritura me hizo reencontrarme con la profesión y la reflexividad sobre mis intervenciones y para ello fue fundamental la supervisión de mis directores, los seminarios de la maestría y el debate con mis colegas de la residencia. Finalmente pude aunar mis lecturas propias de la carrera de grado (aquellas de las cuales me había alejado por considerarlas muy macro-estructurales) con las lecturas etnográficas y las producciones de diversas experiencias en torno a la problemática que deseaba estudiar. La síntesis de este recorrido es la presente tesis donde se combina el estudio de la toma, con mi lugar en la toma. El cuadernillo que me obsequió mi director vino a consolidar y profundizar ese recorrido marcado por búsquedas que me llevaron a la Etnografía. Realizarla me ayudó a responder la pregunta de mi disciplina y el quehacer profesional en el contexto de un trabajo asalariado en un efector de salud de un municipio del conurbano, interviniendo e investigando en una toma de tierras. 


\section{CAPITULO 3}

\section{EL TRABAJADOR SOCIAL LLEGA A LA TOMA.}

\section{Introducción}

En este capítulo desarrollaré cómo llegué a la toma del 7 de abril, desde la habilitación de uno de los referentes en los días previos hasta mi participación plena. A su vez iré desarrollando la modalidad de la toma de tierra, con rasgos novedosos para mí, donde la enseñanza que adquirieron algunos referentes en tomas anteriores o en la militancia piquetera será fundamental para esos primeros días. También referiré brevemente una biografía de los dos principales referentes, sus trayectorias, sus condiciones de vida y cómo el encontrarse en una toma les permitió comenzar a pensar en hacer otra toma. Mi trato con ellos se dio a partir del trabajo asistencial en la salita y la particularidad de que a Emilio lo había buscado con la idea de entrevistarlo para un trabajo de la maestría. Esta entrevista estaba enfocada en la toma del asentamiento 9 de mayo en el año 2002, luego de que leyera su nombre en un expediente en la salita que lo relacionaba a esta. Emilio y Ariel se irán incluyendo en mi red informal de trabajo y yo seré parte de la de ellos. Mi participación en la toma irá de la mano de ellos y siempre en el marco de mi trabajo en la salita, donde además debía responder a la demanda de otros barrios y donde el reconocimiento y la tensión de mi lugar profesional serán parte constante de este proceso.

\section{El trabajador social llega a la toma.}

El día 6 de abril de 2011, aprovechando que no había concurrido mucha gente a la salita, completé informes y encuestas sociales para recursos y pensiones por invalidez. Generalmente los lunes y miércoles veía un promedio de 20 a 25 personas por día, siendo el viernes el día menos concurrido por lo cual terminaba los trámites que iniciaba los días anteriores. Los jueves los destinaba a realizar visitas domiciliarias. Según mis registros entregaba unos 50 trámites cada 10 días, sin contar los bonos de alimentos que la gente retiraba en el depósito del Cruce de Varela, ni las derivaciones a Desarrollo Social pidiendo mercadería (una vez que se me acababan los 50 bonos mensuales).

Ese día, había recibido temprano una llamada de una colega de Desarrollo Social del municipio para que vaya a un operativo de pensiones que consistía en completar informes sociales en una sede designada por el municipio para centralizar la demanda de todo el distrito. Esto, desde mi parecer, iba en contra de los principios de los informes sociales que necesariamente insumen 
una visita domiciliaria como acostumbraba a hacer en la salita. No me gustaba la idea de hacer informes a personas que no conocía y que no volvería a ver y más aún considerando que eran pensiones por invalidez laboral por lo cual seguramente surgirían aspectos vinculados a la salud que encontrarían mejor solución en el trabajo de la salita. Me negué a la convocatoria argumentando que ese jueves tenía que coordinar la reunión de la Red contra la violencia familiar del barrio, esta idea disgustó a la colega del área de pensiones de Desarrollo Social que me sugirió que vaya “... un ratito Luciano, para que no piensen que tenes mala voluntad”. Luego de la llamada vino a verme el "Churro" acompañado de su novia. Al "Churro" lo conocía desde que ingresé en el 2005 cuando fui a dar una charla de sexualidad a un comedor del Movimiento “Independencia”, una escisión del MTR (Movimiento Teresa Rodríguez). El "Churro" tenía 15 años en el 2005 y ayudaba cocinando. Esa vez fue cuando Norma, la referente del comedor, me dijo que yo hablaba como los piqueteros y todos se rieron.

En esta ocasión, con el "Churro" hablamos de sus problemas con el consumo del paco, de la rehabilitación, de la necesidad que se cuide, de la policía y de los "transas" y le recordé que no era buena idea asaltar una cocina de paco mucho menos en el mismo barrio. No le pude ofrecer ninguna alternativa para el tratamiento de su adicción ya que el CPA (Centro de Prevención de Adicciones) y el Cevareso (Centro Varelense de Rehabilitación Social) implicaban la presencia de su familia y él no quería la última opción era una "granja" de la Iglesia Católica pero sobre ellos me comentó: “me mandan a Misiones o Paraguay, Luciano, ¿qué hago con mi novia?” Nos despedimos y le pedí que me llamara si andaba complicado, ya hacía un tiempo que habíamos intercambiado los números de celular. Ese mismo día tenía planeada una reunión con colegas comprometidos con la conformación de un espacio público para el debate sobre las políticas públicas, cuando se sucedió la visita que me habilitó a participar en la toma.

Extracto del cuaderno de campo. Miércoles 6 de abril del 2011. Atención en el CAPS.

Antes de ir a la reunión, viene Emilio Saldivar y Leonor: "Luciano queríamos avisarte que hoy a la noche vamos a tomar unos terrenos, somos 40 familias bien, sin drogas ni nada, si querés haceme la entrevista allá este viernes.

Eso me dijo Emilio, y lo felicité, al hacerlo no pude dejar de pensar en las condiciones habitacionales de él y su familia, que tan bien había conocido. Emilio Marcelo Saldivar había sido un misterio para mí durante los primeros años de trabajo en la salita, el único dato que tenía fue un expediente del año 2002 sobre la conformación del asentamiento 9 de mayo; lo 
encontré en el 2008 y en el mismo se lo mencionaba como referente. En ese expediente se mencionaba desde distintas instancias del Estado municipal a dos referentes de las personas que estaban ocupando el predio, David Saldivar (Oviedo) y Raúl Grieves (Nafta). Al "Nafta" ya lo conocía por comentarios de algunos vecinos y de Mary. En cambio, de David Saldivar no tenía mayores referencias. En ese año 2008 le pregunté a varios vecinos, algunos me dijeron que era alguien que estaba con el municipio, otros directamente no lo ubicaban. Finalmente, ya en el 2010 se acercó a la salita. Era la primera vez que venía a pedir que le hiciera una visita por recursos. Me contó que vivía con sus 4 hijos, todos menores de cinco años y su mujer en el asentamiento 9 de mayo en una vivienda de chapa y que era cartonero. Antes de irse le pregunté si él era el Saldivar que había liderado la toma en el 2002, sonriendo me respondió que sí. En ese año, en la maestría en Ciencias Sociales de la UNLP tenía como posible tema de tesis la conformación del asentamiento del 2002. Sin mucho tacto y ansioso por haber dado con el otro referente le pregunté si le podía hacer una entrevista sobre el 2002. "Cuando quieras, Luciano" respondió. Ahí comenzamos a relacionarnos. Le hice una encuesta social ese año, otra en el 2011 y una encuesta y varios informes sociales. Cada vez que visitaba el asentamiento 9 de mayo me acercaba a tomar mate con Emilio. Estaba preocupado porque el terreno donde vivían era prestado y la casa era precaria. Emilio vivía mal, "el gallinerito" como él le decía, era una casilla de menos de 8 metros cuadrado en peligro de derrumbe, el techo era de chapa al igual que algunas paredes, en el fondo del terreno había un enorme pozo ciego descubierto que se agrandaba con cada lluvia. En ese entonces no tenía trabajo, ni plan social, ni camas. En el informe que realicé para Desarrollo social, con varias copias para que las llevara adonde él quisiera $^{49}$, daba cuenta de la difícil situación:

La vivienda de la familia es de material mixto, (...) Consta de un solo ambiente sin terminar y un baño sin instalación. Los niños se encuentran en situación de riesgo y son propensos a contraer IRAB en el periodo invernal. El agua que toman no es potable y hay focos de infección en la zona, según denuncia el informe citado. La familia se halla bajo la línea de indigencia, subsisten por ingresos esporádicos e informales, no tienen obra social ni aportes jubilatorios. No cubren la canasta de alimentos ni las necesidades esenciales. Subsisten por un ingreso de plan social y trabajos de recolección de cartón lo cual se dificulta porque le han sustraído el

\footnotetext{
${ }^{49}$ Una modalidad que adopté fue que además de las encuestas sociales le realizaba a quien quisiera un informe social hecho en la computadora con varias copias firmadas para que soliciten recursos en otros lugares.
} 
caballo que utilizaba para tales trabajos y luego se le rompió el carro donde carga el fruto de la recolección... ${ }^{50}$

Esta situación le generaba angustia: "el problema Luciano, es que estos quieren comer todos los días y a veces lloran de hambre”, solía decirme señalando a sus hijos. En una de las visitas que le realicé pude referirle “...mi sorpresa por las condiciones en las que vive, sin hogar propio, en una casilla en peligro de derrumbe, todo lo contrario, al Nafta. Me responde que siempre fue honesto. ",51

En los encuentros que fuimos teniendo y en la entrevista posterior a la toma del 7 de abril, Emilio me detallará su trayectoria militante. Comenzó a participar del MTR en el año 2000 hasta el 2008 cuando se suma hasta el 2011 a la ATV (Asociación de Trabajadores Varelenses fundada por Walter López, ex integrante del MTR). Al MTR se acerca por estar desocupado y buscar obtener un plan social. Quirós (2006) señala que formar parte de una organización es una posibilidad, entre otras, de obtener beneficios del Estado y también una forma de darle sentido a la vida, de mantenerse ocupado, de obtener autoestima y respeto. En este sentido Emilio, cada vez que se presentaba, decía que era piquetero aún años después de no estar en la organización y siempre asociándolo con la honestidad como sinónimo. En su trayectoria en el MTR y la ATV, tendrá el plan barrios, manejará un comedor, realizará acampes, piquetes, se encadenará en el congreso de la Nación ${ }^{52}$, sería detenido en la cárcel de Magdalena en el 2001, reprimido varias veces y no asistirá al nacimiento de alguno de sus hijos. Emilio me relató cuando fueron detenidos con el MTR en el 2001 y en la cárcel los llamaban presos políticos “... nos agarraron por causa política, porque lo molestábamos a los políticos, ya que andábamos luchando por la gente (...)” Para él la política estaba asociada al beneficio propio a los avivados y quienes la hacen son los políticos; son ellos los que tienen la posibilidad de acceder y manejar los recursos del Estado. En el movimiento también había aprendido sobre cómo organizar las tomas.

Al rememorar la toma del 9 de mayo, Emilio mencionó algo novedoso para mí: la presencia del MTR en el núcleo fundacional del asentamiento 9 de mayo, tanto por la participación de varios integrantes de la organización en la toma y el apoyo "Nosotros estábamos del lado de adentro,

\footnotetext{
${ }^{50}$ Lozano Luciano "Informe social sobre la familia Saldivar". Año 2010.

${ }^{51}$ Lozano Luciano. Cuaderno de campo de Servicio Social del CAPS La Esmeralda. Año 2011.

${ }^{52}$ Diario Varela al día "Levantaron el campamento piquetero 06/05/2010 El dirigente había dicho en Varela al Día que habría de acampar en la Plaza de Mayo y se encadenaría para sacar el conflicto afuera. No fue a Plaza de Mayo, fue a Plaza de los Dos Congresos, el martes a la mañana. López y otros integrantes de su movimiento acamparon, volantearon la zona y uno de los seguidores del "Uruguayo" se encadenó en el Congreso"
} 
estaba rodeado toda la vuelta, y del otro lado, estaba el MTR que nos estaba apoyando, después vino el cura que también nos dio una mano",53.

"Yo la aprendí en el MTR que hablaban de tomas. Lo que tiene es que yo escucho mucho y escuchaba que en el Chaco hicieron tomas y que se organizaban por cuadra poniendo un referente, cosa de no ir a la gente sino al referente y que el referente hable con la gente. Y ahí organizamos más o menos con "Nafta” (en el 2002) y lo armamos, a la cual lo mismo hicimos con Ariel (en el 2011) que organizamos por sección y cada cual se encargaba de su gente."

La maestría me llevó a conocer a Emilio y él me llevó al nuevo asentamiento para que pueda escribir mi tesis de maestría. Esa relación se repetiría con otros referentes.

\section{La toma del 7 de abril.}

Emilio y Leonor se conocían del asentamiento 9 de mayo. Antes de verme en la salita, ellos sabían que recientemente el sábado 2 de abril, a unas treinta cuadras del 9 de mayo, se había conformado el segundo asentamiento en lo que iba del año en Florencio Varela. El primero había ocurrido en el barrio Santa Teresa, lindante al asentamiento 9 de mayo, a mediados del mes de febrero. Esta toma había sido iniciada por un grupo de vecinos estafados con la venta de unos lotes por un subcomisario retirado y ante la falta de respuestas del municipio frente a sus reclamos, decidieron tomar unos terrenos y se les sumaron otros vecinos más, acompañados por Guillermo "el pelado" un ex militante del $\mathrm{ARI}^{54}$. La policía había impedido los intentos de entrar a los terrenos, entonces el grupo encargado de la toma decidió armar unas carpas en la vereda mientras algunos se dirigieron a pedir ayuda al abogado Robles y a la parroquia Santa Teresa. Aún en abril no había acuerdos con el municipio. En tanto, el segundo asentamiento se había generado en Villa Argentina (en las calles 529 y 536) otro barrio relativamente cercano. La toma se encontraba en un predio donde ya habían existido otras disputas. Éstas estaban relacionadas con la instalación de unas antenas de Nextel en terrenos que ya estaban asignados para un futuro plan de viviendas. Desde el municipio, la directora de tierras, María Rosa Tedesco se había reunido con los ocupantes en ese lugar y les había señalado que esos terrenos eran para un espacio verde y los invitó a que abandonen el predio. La respuesta de la gente había sido categórica, nadie confiaba en que la municipalidad diera otro tipo de solución más

\footnotetext{
${ }^{53}$ Ídem 5.

${ }^{54}$ Coalición Cívica para la Afirmación de una República Igualitaria.
} 
que inscribirlos en la interminable lista de personas que esperaban recibir una casa del Plan federal. Ante este panorama muchos habían acudido al abogado Robles y al cura Camilo.

Emilio y Leonor no desconocían lo difícil que podía resultar hacer una toma, pero más allá de eso esta idea venía dándose en la cabeza de ellos y en la de muchos conocidos del barrio, con los que se encontraban tomando mate, en el almacén o en la verdulería de Ariel. A veces, algunos contaban que estaban complicados con el alquiler o que los pibes iban creciendo y no tenían cómo tener un hogar.

Leonor, Norma, Emilio y Ariel se juntaron esa noche del seis de abril en la casa de Ariel en el barrio La Esmeralda. A Ariel le costaba dormir, había comprado esa casa a la vuelta de la salita y lo estafaron. Las cartas documentos se sucedían semanalmente y ni siquiera asistió al juicio porque no pudo pagar un abogado. Algo había aprendido, era un mito que por tener hijos no lo iban a desalojar. Y tenía seis hijos, nietos y uno de sus hijos andaba complicado porque los suegros le impedían ver a su novia y a su bebé. Ariel no era de quedarse quieto, había pedido ayuda en la municipalidad para conseguir un terreno pero sentía que los del gobierno lo “bolaceaban”. Las cosas se iban complicando, ya había cerrado la verdulería y en poco tiempo ni siquiera tendría plata para alquilar algo por ello se sentía cada día más cercado. En esos días, unos conocidos le mencionaron la toma de tierra cercana al barrio Santa Teresa, le dijeron que había carpas repletas de gente esperando que les asignen un lote. Decidió ir y de lejos veía el humo de las ollas que traían el olor a guiso y a matecocido, se acercó y vio a la policía rodeando las carpas y numerosos nenes jugando en la calle. Entre tantas caras extrañas divisó a Emilio con quien tenía trato desde hace años y solían verse en la verdulería. Se juntaron en una de las carpas y charlaron. Hablaron de lo difícil que sería conseguir un lote en esa toma Emilio le contó sobre los grupos de piqueteros en los cuales había participado y sobre la toma del 9 de mayo. Ariel le dijo que había visto unos terrenos en el barrio Libertad, al fondo, cerca del Club Cristal pero que no se animaba a meterse. Emilio sonrió, coraje no le faltaba y la idea lo entusiasmó, "yo te hago el aguante" respondió. Antes de irse de las carpas, Ariel consiguió el número de teléfono del abogado Robles.

Les avisaron a varios conocidos más que estaban en la misma y por cada familia interesada iba un representante, en algunos casos iban familias enteras con los chicos. Muchos de ellos se habían anotado en el municipio, a algunos incluso les habían ofrecido terrenos separados por pasillos, en Los Pilares, pero eso era muy lejos del barrio y los pasillos sonaban más a una villa donde las ambulancias no entraban. Y ellos querían vivir en un barrio.

Esa medianoche se encontró en una esquina y empezaron a caminar la distancia hasta los terrenos que habían pensado: atrás del Club Cristal y al lado de un productor hortícola de 
nacionalidad portuguesa. Para no llamar la atención se metieron por medio del asentamiento 9 de mayo y no por la avenida Novak ni por la calle Humahuaca (lo que hubiese sido más rápido pero con el riesgo de que las luminarias los delaten). En la caminata por esas calles de tierra, iban sigilosos, casi sin hablar, escuchando a los perros que les ladraban y esquivando las miradas curiosas que se asomaban por las ventanas. Recorrieron unas diez cuadras. Salieron a la altura del club en las calles 521 y 580. Allí los estaba esperando uno de los hijos de Ariel en un viejo Peugeot donde habían cargado las carpas, ollas, frazadas y otros elementos para instalarse. Ariel le indicó a su hijo que se llevara el auto a unas cuadras, por si las cosas se complicaban.

Uno de los referentes del Club Cristal, que trabajaba para un concejal, se acercó y empezó a discutir con Emilio. Ambos ya se conocían de antes, del barrio, de "la política" como decía Emilio. El referente del club les dijo que los terrenos descampados le pertenecían, entonces tomaron el campo de al lado. "No nos peleemos con nadie, hoy nos sirven todos", repetía Ariel. Al poco tiempo, alrededor de la 1:30 hs AM estaban rodeados por la policía y por el grupo GEO. Algunos agentes les apuntaban a la cabeza con escopetas. Uno de los comisarios que comandaba el operativo era de la comisaría de la zona y se quedó hablando con Emilio que ante la amenaza de desalojo le recordó que él era piquetero, que ambos conocían a Walter de la ATV y que nadie se iba a ir. Finalmente, el comisario, que concurría a una Iglesia Evangelista donde se cruzaba con mucha gente del barrio, les aconsejó que se corrieran a la vereda.

A las 4:00 AM una llamada despertó a Pedro Robles. Su mujer y su hija estaban acostumbradas a esas llamadas. No era la primera vez que unos vecinos lo buscaban para que los ayudara en la ardua lucha por la casa propia. Recibido de abogado hacía unos diez años, prefería no litigar y ser docente de una escuela que el mismo había ayudado a fundar. Había sido concejal radical entre 1993 y 1997 y funcionario en el gobierno de De la Rúa hasta que el desencanto con el viraje económico del gobierno lo había llevado de nuevo a los barrios, a esquivar cargos políticos y fortalecer la organización a la cual pertenecía el Centro de Participación Popular Mugica. Les aconsejó lo mismo que el comisario, que se corrieran a la vereda así no los podrían reprimir y se comprometió a verlos ese mismo día. Antes de las 10 de la mañana ya se veían 50 carpas armadas y decenas de personas haciendo cola para anotarse. Los patrulleros vigilaban de cerca.

Algunos de los que tomaban la tierra se habían anotado en los listados del Plan Federal de vivienda $^{55}$, sólo en Varela había más de 25.000 inscriptos, otras personas ni siquiera confiaban

\footnotetext{
${ }^{55}$ Aramburu, F.; Chiara, C. (2016) refieren sobre este plan:
} 
en esa posibilidad. La mayoría de las personas en la toma provenían de diferentes barrios cercanos: Santa Rosa, La Esmeralda, Villa Argentina, Don José, del plan federal cercano y algunos venían de Quilmes.

\section{La invitación de Emilio y Leonor.}

El jueves 7 de abril uno de mis días reservados para visitar el barrio lo comencé debatiendo con Amelia sobre los criterios para realizar informes sociales ya que había observado que las residentes no utilizaban indicadores como línea de pobreza, indigencia o NBI (Necesidades Básicas Insatisfechas) y que los informes eran mayormente descriptivos y relativos a la interpretación de la persona que lo leyera. Amelia me indicaba la importancia de saber cuál era la finalidad del informe dentro de la estrategia de intervención profesional. Le conté sobre la reunión en CARITAS con los colegas donde pensamos sistematizar los informes para tener nuestra propia estadística sobre pobreza en Varela. Acordamos con Amelia organizar un encuentro con mi hermano (investigador y docente de la UNLP) donde se discutiera sobre indicadores y estuviera dirigido a la residencia de trabajo social. Al mediodía fuimos a visitar a Tamara, una chica trans del barrio Santa Rosa hospitalizada en Mi Pueblo luego de que intentaran asesinarla unos días atrás. La madre y el padrastro de Tamara nos contaron que el día del ataque no fue internada y el martes cuando la llevaron a la salita para curarse los médicos la enviaron de urgencia al hospital debido a las heridas sin suturar. Los médicos de la salita no podían creer que le hubieran dado el alta en esas condiciones. El padrastro de Tamara nos contó que el ataque fue en la calle y ella quedó tendida en el piso hasta que vino la ambulancia. En el

\footnotetext{
“La reincorporación de la cuestión habitacional a la agenda pública, en el año 2003 durante la presidencia de Néstor Kirchner, provocó un rotundo giro en materia de políticas habitacionales que persiguió tres objetivos: la generación de empleo, la disminución del déficit habitacional y la reactivación de la economía local a partir de la movilización del mercado de la construcción3. Estos objetivos fueron puestos en práctica por medio de diversos programas, conocidos como los Planes Federales de Vivienda." (...) El primer Programa puesto en funcionamiento en este contexto es el Programa Federal de Emergencia Habitacional (Techo y Trabajo). El cual combina dos objetivos, por un lado, la construcción de viviendas y, por el otro, la generación de empleo, a partir de cooperativas de trabajo conformadas por los beneficiaros del Programa Jefas y Jefes de Hogar. De este modo, incluye organizaciones sociales en su ejecución y articula instancias gubernamentales como ser: el Ministerio de Planificación Federal, Inversión Pública y Servicios de la Nación; la Subsecretaria de Desarrollo Urbano y Vivienda; el Ministerio de Desarrollo Social y el Instituto Nacional de Economía Social y Solidaria. Posteriormente, en el 2004, el Gobierno Nacional lanza el Programa Federal de Mejoramiento de Viviendas y el Plan Federal de Construcción de Viviendas. El primero de ellos, conocido como "Mejor Vivir", se origina como consecuencia de la valoración del déficit habitacional arrojado por los datos del Censo 2001, el cual reflejaba la existencia de un importante stock de viviendas deficitarias. Por lo tanto, el objetivo de dicho Programa será abordar las obras de refacción, completamiento y ampliación en viviendas familiares entre sectores que se vieran imposibilitados de acceder a un crédito" (pp.6 y 7)
} 
hospital, además de no curarla, los camilleros se burlaron de ella. Les explicamos que podían hacerles una denuncia, y nos respondieron que si la hacían no iban a poder ir más al hospital. El viernes 8 de abril empezamos la mañana con las residentes debatiendo sobre situaciones graves y cómo abordarlas. Les conté que Desarrollo Social no estaban enviando planillas (encuestas, planillas de programas alimentarios, pensiones) desde hacía quince días. Esta situación me obligaba a ir a buscarlas y perder tiempo en eso, además del mal humor que me generaba ir a ese lugar y cruzarme con mis jefas.

Al mediodía decidí realizar la visita al nuevo asentamiento, para ello le pedí a Mary Herrera que me acompañara. Decidí ir con ella por ser referente del asentamiento 9 de mayo y promotora de salud de la salita. Nunca había estado en un proceso de tomas de tierras y al ir con Mary consideré que era una manera de dejar claro que contaban con mi apoyo, pese a que trabajara para el municipio. En mis primeros años de trabajar en Varela, me había pasado muchas veces que el entusiasmo de trabajar con la gente, de estar en el barrio, me hiciera sentir que estaba de nuevo en el comedor piquetero más allá de mi situación laboral. También, es cierto, era una forma de sobrellevar un trabajo que me generaba contradicciones y frustraciones. Pero invariablemente sucedía alguna situación donde quedaba claro, de que por más que yo me sintiera "del lado de la gente" mi pertenencia laboral y el lugar que representaba se imponía. La primera vez fue en octubre del 2007 cuando un temporal muy fuerte afectó a la mayoría de la población de Florencio Varela. En ese momento el municipio organizó operativos con Defensa Civil para distribuir chapas, colchones, frazadas y mercadería, a la vez en los Centros de Salud los trabajadores sociales recepcionábamos la demanda haciendo listados de damnificados (los cuales eran numerosos, recuerdo haber visto en la salita a 200 personas en tres días). Las personas, en su mayoría mujeres, venían con sus hijos pequeños, con frio, hambre, tristeza y enojo. Muchas de esas personas me exigían que les entregara los recursos inmediatamente, que en Desarrollo les habían dicho que dependía de mí, que hasta me habían dado botas e impermeable para que les haga la visita. Me repetían y pedían que vaya a sus casas, que vea como había quedado todo destruido. El clima se tensaba, la salita repleta de personas y afuera en la vereda muchas más esperando para verme; mis compañeros de la salita consideraban que era parte de mi trabajo y por ello no participaban en modo alguno de la atención a esas personas. Transcurridos algunos días la situación fue agravándose, dado que seguía lloviendo y las respuestas asistenciales no cubrían a la gran cantidad de afectados. En ese marco fui convocado a una reunión en la Secretaría de Desarrollo Social en Varela como decía la gente del barrio, a tres kilómetros de la salita en el centro del distrito. Al llegar a la Secretaría y encontrarme con otros colegas, me fui enterando lo difícil que estaba resultando la situación y el delicado lugar 
que teníamos como trabajadores sociales: a una colega del barrio Villa Hudson, donde trabajaba hacía 14 años la habían retenido los propios vecinos, impidiéndole salir, y luego llamaron a Desarrollo Social advirtiendo que la "asistente social no se va a ir hasta que no nos den las cosas". A otras colegas las habían amenazado directamente. Recuerdo que el edificio de Desarrollo Social estaba cerrado y lo custodiaba la policía. Con otros colegas y los referentes del gremio CICOP, pensábamos qué podíamos hacer y en esos instantes se me acercó un policía y me avisó que “afuera hay mucha gente que pregunta por Luciano Lozano”. Al salir la policía cerró la puerta e inmediatamente me rodearon unas 50 personas que comenzaron a increparme, seguía lloviendo aún y los insultos se mezclaban con los ruegos, el enojo y la desesperación. Venían caminando desde la salita, algunas personas traían a sus hijos de la mano, me querían ver porque les habían dicho en la municipalidad que yo tenía las chapas. Recuerdo que intentaba llamar por su nombre a las personas que conocía de esos dos primeros años en Varela y en medio de los gritos explicarles cuál era mi lugar, mis posibilidades, "si no podés hacer nada, para que carajo estás" me respondió una señora a la que no conocía y parecía liderar el reclamo. Finalmente, una colega y amiga salió en mi defensa ${ }^{56}$ y desde Desarrollo Social aceptaron negociar. Ese día fue una de las pocas veces en que pensé en buscar otro empleo y aprendí en pocos minutos la complejidad del trabajo en el cual estaba. Asimismo, estos incidentes me enseñarían a transitar los siguientes años, aunque en algunas ocasiones como se verá más adelante, me olvidaría de la complejidad de mi lugar guiado por el entusiasmo.

En la ocasión de visitar por primera vez el asentamiento tomé los recaudos necesarios por eso el pedido a Mary de acompañamiento. En mi cuaderno de campo anoté las impresiones:

Extracto del cuaderno de campo. Viernes 8 de abril del 2011.

Al mediodía voy con Mary Herrera a visitar al nuevo asentamiento. Son 6 manzanas en Santa Teresa. Al llegar nos rodean unas 20 personas, hay 3 patrulleros a $100 \mathrm{mts}$. Uno de los que habla y parece ser el referente me agradece que esté allí, le aclaro que no soy responsable ni enviado por el municipio, que, por el contrario, que la idea mía es ver cómo podemos acompañarlos, pregunto por Emilio, pero no está.

\footnotetext{
${ }^{56}$ Gisela Gómez, amiga y colega, con quien había cursado en la facultad, le exigió a la policía que abriera la puerta y a los gritos se interpuso entre las personas y yo, aclarándoles que no era mi responsabilidad la entrega de recursos. Esto generó cierta presión a las autoridades de Desarrollo Social que recién ahí decidieron abrir la puerta y comenzar la negociación.
} 
Hay gente que conozco del barrio. El referente me agradece lo que hice por su nieto y ahí me doy cuenta de que es Ariel Márquez, el padre de un chico que está en pareja con una chica de 16 años y que apoye frente a una denuncia en Niñez por parte de la madre de la chica.

La gente es muy cálida, están sobre la vereda en carpas de nylon, están ahí por consejo de un comisario que fue el $3^{\circ}$ día y del abogado del Centro Mugica. En la vereda nadie puede reprimirlos.

El referente me dice que la idea de ellos es organizarse por asamblea, aunque no dice esta palabra, "entre todos" refiere. Dice que son familias necesitadas. Mary agrega su experiencia con el asentamiento "9 de mayo" "hay que lucharla" les dice. Les digo que si tienen chicos enfermos pueden llevarlos a la salita, me dicen que los nenes duermen en sus anteriores hogares.

Recorro la hilera de carpas y voy hablando con la gente que conozco, están entusiasmados y piensan que les van a dar las tierras. Algunos me hacen consultas puntuales por sus problemas.

Luego viene Emilio, me recibe muy bien, me cuenta que están asesorados por Robles y que no quieren que se metan políticos en la toma "yo puedo decirle a Martino que venga, pero va a plantar bandera" "queremos que sea visto como una pelea de familias".

El sábado tienen reunión con Robles y otros asentamientos. Me dicen que van a dejar un lugar libre para que vaya a atender ahi.

En la vereda estuvieron unos días. Recibieron visitas: el abogado Robles, Tania, trabajadora social de la parroquia Santa Teresa, Enrique y Camilo, curas del mismo lugar. Estos últimos les llevaron mercadería y celebraron una misa. De la salita La Esmeralda además de mí y de Mary fueron las residentes PRIM. En ese primer encuentro Mary les relató su experiencia en el 2002. Ese día decidí que el trabajo con ese incipiente asentamiento sería unas de mis prioridades, esta decisión indudablemente se enmarcaba en la red informal que fui conformando con Mary, Tania y los curas que se fue expandiendo y constituyendo una red de trabajo en conjunto que guió mi quehacer profesional hasta la nueva toma.

Me sentía cómodo por la invitación; la visita de Emilio y Leonor y luego el agradecimiento y bienvenida de Ariel, constituyeron la habilitación para que pudiera concurrir a la toma. Es interesante ver que la visita se dio antes de la toma, lo cual marca cierta confianza hacia mí en el sentido de que consideraron que no iba a avisar a mis autoridades del municipio y y a su vez 
puede ser interpretado como parte de la estrategia para sostener la toma tener el apoyo del Centro de Salud o al menos del servicio social. La frase "no nos peleemos con nadie" de Ariel fue parte de esa estrategia. En tanto, la presentación que hicieron Emilio y Leonor de lo que iban a hacer "una toma de familias, sin drogas" puedo pensarlo que no fue solo un modo legítimo de presentarlo sino un modo de dirigirse a mí como trabajador social, ligado al control y vinculado con la experiencia de Emilio con los asistentes sociales que habían realizado el censo del año 2002 y habían volcado todo en un expediente. El expediente de la toma del año 2002 había suscitado mi curiosidad por Emilio, y ahora él mismo (y Leonor) me habían llevado hacia la nueva toma donde la idea era "no peleemos con nadie, todos nos sirven". Finalmente, el trabajador social estaba en la toma. De algún modo, el comisario, el abogado Robles, el cura Camilo y yo, a la sazón un representante de la salita, estábamos allí haciendo algo. Estábamos colaborando, estábamos sirviendo a la toma. El comisario con su consejo de quedarse en la vereda, así él no tendría que actuar, el abogado Robles confirmando el consejo del comisario, el cura asistiendo con víveres y dando la misa, y yo visitándolos para confirmarles que me ocuparía de los chicos enfermos. Sin duda, en poco tiempo Emilio y Leonor se habían comportado con mucha inteligencia y armado una red de contención para la nueva ocupación sobre la que habían conversado durante días en la verdulería de Ariel.

\section{Conclusión}

Al principio, Emilio era un nombre un expediente archivado que despertaba mi curiosidad entre muchos papeles en el consultorio de la salita. La posibilidad y la legitimidad para conocerlo y trabajar con él se dio por el trabajo asistencial. A partir de este trabajo tuvimos encuentros frecuentes, mediados por informes, encuestas sociales, pedidos de mercadería, que fueron sembrando la posibilidad de llegar a la toma. Además, mencionarle a Emilio mi interés por entrevistarlo para la maestría fue parte de lo que generó su invitación.

En tanto, Ariel me recibió bien por saber cómo había intervenido con su hijo y su nieto. Y claro, porque mi presencia, la de la salita, era parte de la búsqueda del consenso que necesitaban para no ser desalojados, al igual que el discurso de "una toma de familias, sin drogas" diferenciándose de las "villas". Mi visita al asentamiento fue acompañado de Mary quien era conocida en el barrio por ser referente de un asentamiento y de la "Copa de leche" fue parte de querer demostrarles a las personas que yo estaba de su lado, sabiendo por mis experiencias anteriores lo delicado que podía resultar mi lugar. Darle prioridad a la toma como objetivo profesional fue tanto por la vulnerabilidad de esas familias (que yo consideraba debían ser 
abordadas desde la salita) por la invitación de sus referentes y por la fascinación e interés que me producía el tema. De algún modo sentía que era la posibilidad de trabajar un tema estructural desde la profesión en compromiso con las clases populares y con todo el interés académico que me había despertado la maestría en esos años de cursada.

La habilitación/invitación de los referentes fue la puerta de entrada a mi participación en la toma, lo que no significaría que eso solo alcanzara para sostener mi presencia allí.

Sobre la toma en sí, no se parecía demasiado a las descripciones que había leído en la literatura no habían armado grupos de trabajo, ni siquiera tenían planos de los terrenos con los lotes asignados, tampoco contaban con la ayuda de referentes de otras tomas u organizaciones sociales, políticas ni eclesiales. Quizás la mención de Ariel a decidir “entre todos" podía remitir a la organización en modo asambleario que coincide con otras experiencias. En tanto, algo novedoso para mí fue la indicación de correrse a la vereda para evitar la represión policial, aunque en las entrevistas que hice,Ariel y Robles lo mencionarán como una estrategia utilizada en Varela.

Tanto Emilio como Ariel se encontraban viviendo en situación de indigencia y habían desarrollado múltiples estrategias antes de decidirse a hacer la toma: alquilar, intentar comprar, anotarse en listado del Plan Federal de Viviendas, hablar con políticos o incluso participar de otras tomas. Lo cual coincide con el planteo thompsiano que me realicé en el apartado anterior sobre la inutilidad de las explicaciones causa/efecto. En estas búsquedas por resolver la cuestión habitacional, para ellos nada había resultado, pero este recorrido, esta experiencia de buscar diferentes estrategias les había dado herramientas que luego utilizaron en la toma. En el caso de Emilio fue más evidente por su experiencia de militancia en el MTR y la ATV, por haber participado de la toma del 9 de mayo. Por eso será él quien negocie con el dirigente del Club Cristal y luego con el comisario de acuerdo a sus propios criterios e intereses. La urgencia de esos momentos no coincidirá con los deseos democráticos que planteaban. 


\section{CAPITULO 4}

\section{FORMAR UN CAMPAMENTO INDIO. ENTRE LAS PROMESAS, LA FRAGMENTACIÓN Y LA SOLEDAD DEL INVIERNO.}

\section{Introducción}

En este capítulo daré cuenta de la primera toma del 7 de abril. Para facilitar la comprensión lo expondré en cuatro apartados, utilizando un relato coloquial en formato de crónicas entrelazándolo con el registro etnográfico. Este primer proceso tuvo varias etapas que los propios nativos nombraron de manera diferente. Mi análisis contemplará estas denominaciones e incluirá la figura de los principales referentes Ariel y Emilio, y las intervenciones de las agencias del Estado, operadores políticos e instituciones y organizaciones sociales. Estas intervenciones potenciarán las diferencias entre ambos referentes y en la manera de organizarse para seguir disputando los terrenos ocupados. Mi recorrido en este proceso estará atravesado por ello y por la búsqueda individual y como parte de la red informal de trabajo de garantizar que la toma siga vigente. Analizaré a partir del registro de mi cuaderno de campo cómo el trabajo en las cárceles y en el asentamiento se cruzaron inevitablemente y cómo mi propio entusiasmo por acompañar a la toma puso en riesgo mi lugar allí. Esto me llevará a cuestionar mis intervenciones allí y a debatir con otras colegas el por qué y para qué de un trabajador social en la toma.

\section{En la vereda}

Emilio y Ariel, desde el momento de la toma, comenzaron a pedir recursos para garantizar la permanencia allí (leña, comida, leche, ollas, entre otros) y a establecer y fortalecer alianzas tanto con sectores del gobierno municipal como de las organizaciones sociales y las agencias del Estado. Sin embargo cada uno paulatinamente transitará caminos diferentes.

Tres días después de haberse instalado en la vereda los recibí en la salita. Al entrar me pidieron leche en polvo para llevar a la toma, por lo cual me dirigí al sector de administración de la salita y tomé dos kilos sin avisar al personal administrativo ni registrar nada. La entrega de leche había sido motivo de disputas y diferencias con mis compañeros quienes solían recordarme que debía entregarse a la población objetivo del plan materno infantil ${ }^{57}$.

\footnotetext{
${ }^{57}$ El Programa Materno infantil de la provincia junto al Ministerio de Salud y Ambiente de la Nación distribuye a todas las jurisdicciones leche fortificada con hierro y zinc, de acuerdo con un índice elaborado y consensuado en el COFESA, y que globalmente cubre el mayor porcentaje de las necesidades de Embarazadas - Madres amamantando a niño/a de 0 a 6 meses - Niños eutróficos de 6 meses. Los criterios de dación de leche según normas nacionales son los siguientes: $2 \mathrm{Kg}$. por mes para embarazadas, desde el 5 to. mes $2 \mathrm{Kg}$. por mes para nodrizas 2
} 
Emilio y Ariel traían un mapa con los terrenos que querían tomar (seguían en la vereda vigilados por la policía) donde se veía los lotes y parcelas. No sabían la situación dominial pero me afirmaron que planeaban extender el asentamiento en el caso de comprobar que el dueño de la chacra aledaña ya habría tomado con anterioridad una franja de $80 \mathrm{mts}$ por $500 \mathrm{mts}$ de largo. En una entrevista posterior Robles me confirmaría de esta apropiación de la tierra por parte del portugués "él se queda con otra parte, en el quilombo dice esto es mío, sin papeles ni nada"58 y agregaría que esta práctica de tomar tierras y agrandar su zona de producción ha sido muy extendida entre los productores hortícolas en Florencio Varela Al parecer, en Varela quienes necesitaban un lugar para vivir no eran los únicos que tomaban tierras.

Este mismo hombre se había acercado a Emilio y a Ariel para amenazarlos y exigirles que se retiren de la vereda. Ese día en la salita hablamos de cuál sería la mejor manera de reclamar en Desarrollo Social, les di mi opinión de que no era buena idea entregar listados con nombres y apellidos ya que les podían fragmentar la demanda individualizándola y haciendo que se enfrentaran los propios vecinos, como había sucedido en el temporal de enero. Le recordé a Saldivar la experiencia del asentamiento 9 de mayo donde él y el "Nafta" Grieves habían canalizado la demanda. Me respondieron que planeaban hacer una comisión y se retiraron con la promesa de vernos pronto y que luego me contarían sobre la reunión que tenían en la municipalidad. Al irse me quedé hablando con mis colegas residentes, Lorena, Pablo y Amelia. Lorena me sugirió que le entreguemos a los referentes del asentamiento una copia del expediente del 9 de mayo que había encontrado en la salita y que llamativamente me había llevado a buscar a Emilio Saldivar.

Mi sugerencia de que no entregaran listados con nombres para evitar el cruce de datos y que se filtre la información entre quienes podían o no acceder a los lotes estaba destinada al fracaso. Una práctica habitual en el municipio de Florencio Varela era justamente la de cruzar datos de las personas con las bases de datos del Estado. Esto mismo acordaron en la primera reunión que tuvieron en el municipio, quedando plasmado en un acta acuerdo. Paulatinamente, tanto Tania como Ariel o Emilio me irían acercando las actas de las reuniones que iban teniendo allí con diferentes funcionarios. Esas actas, me diría luego Robles, serían parte de los argumentos para iniciar la segunda toma dado que eran una muestra cabal de la voluntad de resolver la situación por parte de los vecinos y del incumplimiento del Municipio.

\footnotetext{
Kg. por mes para niños menores de 1 año no amamantados $1 \mathrm{Kg}$. por mes para niños de 1 a 2 años $3 \mathrm{Kg}$. por mes para desnutridos menores de 6 años

${ }^{58}$ Entrevista a Pedro Robles realizada por el autor. Año 2017
} 
Emilio me acercó la copia del acta de la reunión que tuvieron el 12 de abril del 2011:

“En el día de la fecha, se reúnen en el despacho de la Secretaría de Gobierno, Dr. Andrés Watson, y vecinos del barrio Santa Teresa de este Distrito, Sres. Saldivar Emilio, Gómez Oscar, Márquez Ariel Vicente y Robles Pedro.

La presente reunión tiene por objeto el tratamiento de la cuestión planteada por los vecinos respecto de un predio ubicado en Humahuaca entre 521 y La Paloma del mencionado barrio, actualmente ocupado, solicitando conocer la posibilidad de obtener soluciones en cuanto a la problemática habitacional de los vecinos de la zona.

Los vecinos se comprometen a acercar al Municipio un listado con las personas incluidas en la problemática planteada con los datos correspondientes a su identidad y actuales condiciones socio-económicas, solicitando que, una vez entregado este listado se brinde asistencia sanitaria a las personas en cuestión. Los datos vertidos en el listado que los vecinos presenten, serán verificados por personal de la Secretaría de Salud y Desarrollo Social, para continuar reuniendo información a fin de avanzar en la instrumentación de la solución a la cuestión en análisis. (...) Se acuerda una nueva reunión para el día 19 de abril del corriente año..."

En esta primera reunión en el Municipio ya se vislumbraba quienes serían los referentes de adentro de la toma y de afuera, por un lado, Ariel y Emilio, por otra parte Robles, el cura Enrique y el propio municipio, respectivamente. ${ }^{59}$

Dos días después (el jueves 14 de abril) decidí visitar el asentamiento, esta vez acompañado por Mary y las residentes de trabajo social, Lorena (residente de tercer año) y Amelia (residente de segundo año). La presencia de las residentes era fruto del trabajo en conjunto que veníamos realizando desde el 2007, al ser una residencia multidisciplinar (trabajo social, psicología, psiquiatría y los primeros años de medicina general) conformada por una estructura docente y el equipo del centro de salud como referente natural. Las diferentes maneras de ver y abordar las problemáticas del barrio se enriquecían año tras año, merced a compartir situaciones en común, de crear dispositivos de atención (espacio de admisión para salud mental) de organizar y asistir a las reuniones de la Red contra la violencia familiar, y visitar el barrio (las colegas de

\footnotetext{
${ }^{59}$ Tampoco es un dato menor que el funcionario Watson se convertiría al finalizar el mandato de Julio Pereyra en su sucesor en la intendencia.
} 
trabajo social y en ocasiones desde las otras disciplinas se sumaban a mis visitas). Además en el primer año debían realizar un ASIS (análisis de situación de salud) para lo que recaban datos de la población y analizaban sus principales problemas. Para mí, la presencia de ellas (sólo hubo tres varones en todos esos años) posibilitó cuestionar y mejorar mis intervenciones, crear nuevos espacios, debatir teóricamente sobre la disciplina, profundizar las intervenciones colectivas en el barrio, de sostener y ampliar la Red Contra la Violencia Familiar, pensar la interdisciplina y a mi propia disciplina. En tanto, puntualmente, con las colegas de trabajo social nos constituimos en un equipo, cada uno respetando el lugar: la atención en la salita estaba a mi cargo, como así también la realización de visitas e informes sociales, pero participaban de la misma y hacían informes y visitas. Cuando me iba de licencia no podían reemplazarme en mis tareas, salvo en el seguimiento de situaciones graves previamente trabajadas en conjunto y bajo la supervisión de su jefatura. Paulatinamente fuimos acordando una agenda de trabajo, los días de atención en duplas, las salidas al barrio, la asistencia a las reuniones de red. El trabajo con las organizaciones sociales y el nuevo asentamiento fue una prioridad también para la residencia de trabajo social (y posteriormente para todo el PRIM), por lo cual comenzamos a visitarlo y pensarlo en conjunto. En el día anterior a la visita del asentamiento, el miércoles 13 de abril, nos habíamos reunido con integrantes del $\mathrm{FOL}^{60}$ quienes acababan de sumarse a las reuniones de la Red Contra la Violencia. Hacía siete años ${ }^{61}$ que se encontraban trabajando en el barrio Santa Rosa y habían tomados unos terrenos para hacer un comedor y una huerta en las calles Dinamarca entre París y Berlín. Tenían un proyecto muy interesante de autoconstrucción de viviendas que habían presentado en diferentes niveles del Estado (municipal, provincial, nacional) que se concretaría unos años después ${ }^{62}$.

\footnotetext{
${ }^{60} \mathrm{No}$ abundan los trabajos académicos sobre esta organización, pero se destaca las exposiciones que su equipo de abordaje de la violencia de genero ha presentado en diferentes jornadas. Al respecto se puede consultar el trabajo presentado en el año 2014 en las "Jornadas de Investigación, Docencia, Extensión y Ejercicio Profesional (JIDEEP) IX Jornadas de Investigación, Docencia, Extensión y Ejercicio Profesional (IX JIDEE" "Violencias de género: Una mirada interdisciplinaria sobre su abordaje en el marco de una organización territorial. Construcciones colectivas, dificultades y desafíos". Ballesteros, Sofía (Colectivo de Abogados Populares La Ciega); De la Vega, Lucia (Aquelarre, Equipo Interdisciplinario contra la Violencia de Género); Martin, Pilar (Aquelarre, Equipo Interdisciplinario contra la Violencia de Género).

${ }^{61}$ En esa reunión nos dijeron que el frente estaba integrado por la Unión de trabajadores Enrique Almirón (UTCA), MTD $1^{\circ}$ de Mayo, movimientos piqueteros que se unificaban por los principios de antiburocracia, anticapitalismo y clasismo. Además, junto a otras organizaciones estaban formando la "Corriente social y política la brecha" que se concretaría en mayo https://www.anred.org/?p=18878

${ }^{62} \mathrm{http}$ //folweb.com.ar/nota/751/vivir en un barrio organizado por_sus habitantes desde los cimientos . Una de las integrantes del Fol, Celeste, me contaría en una entrevista "sobre el proyecto de viviendas sociales, te cuenta $q$ se ubica en el barrio la Fiat, en la calle Gral. Salvio y Sicilia, a una cuadra de la asociación japonesa, ruta 53 Eva Perón, ex sarmiento, el proyecto fue gestionado en el Estado para materiales y mano de obra para construir 36 viviendas (producto esta gestión, de planes de lucha en la calle) y el terreno no fue tomado, sino que se sacó un crédito en banco provincia, un crédito especial para ong's que se llamaba "fuerza solidaria" para gestionar
} 
En esos terrenos, habían construido una guardería donde comenzaron a idear la Casa de la Mujer Flores Guerreras aunque aclaraban que tenían el objetivo de que en el futuro contara con un espacio físico propio ${ }^{63}$. En esos años se habían ido capacitando en el abordaje de violencia de género con un equipo de profesionales. Su modalidad de trabajo era recepcionar las situaciones de violencia de género en la Comisión de Salud y Género y luego, dependiendo de la gravedad, se pedía asesoramiento al equipo interdisciplinario que funcionaba en la sede del barrio de Villa Constitución en Capital Federal. En esos días de abril pudimos concretar los primeros encuentros y aunque compartíamos un área territorial cercana y teníamos acuerdos ideológicos con el discurso de izquierda de esta organización, nuestra coordinación en esa época solo se circunscribió al ámbito de La Red y al tratamiento de la violencia familiar. Esto se diferenciaba de la coordinación que teníamos con la parroquia Santa Teresa y el Centro Mugica que fue creciendo y pasó del abordaje de situaciones a la coordinación de La Red y luego a la problemática de la tierra y la vivienda. En los años posteriores a mi partida de Varela, desde la residencia seguirían coordinando con el FOL y profundizando el trabajo en varios aspectos hasta realizar un análisis de situación de la salud en el lugar ${ }^{64}$.

La articulación con organizaciones, las reuniones de La Red e incluso las visitas al nuevo asentamiento no estaban incluidas en las tareas esperadas por la Secretaría de Desarrollo Social, lo cual me generaba inconvenientes dado que no podía retrasar el trabajo asistencial (las encuestas sociales, informes para pensiones, etc.), ni descuidar a los otros barrios del área programática. Esto me lo haría saber la Sociedad de Fomento del barrio La Esmeralda, cuyo presidente, un militante del PJ y hermano de una de las enfermeras de la salita, me "mandó a decir" que "andaba mucho por los asentamientos" y "me había olvidado de la gente de la Esmeralda". Estas palabras (en boca de su hermana) eran una advertencia, dada la llegada que tenían desde esa organización a mis jefes. Entonces decidí reforzar mi presencia en ese barrio, ocupándome de algunas situaciones que me informaron por medio de la enfermera de la salita, que por otro lado eran situaciones de personas con graves problemas de salud. Mi modalidad de trabajo con las organizaciones que respondían al gobierno municipal como la Sociedad de

\footnotetext{
el proyecto se armó una cooperativa de vivienda, donde las familias pagaban las cuotas del terreno nada más, que eran muy accesibles para gente humilde, y a su vez se autoorganizaban para definir el funcionamiento del barrio. Es una experiencia más de autogestión de viviendas, pero la verdad llevo mucho esfuerzo, llevo muchos años de luchar para que sea aprobado y 3 años aproximado de construcción en 2 tandas...las cuadrillas de construcción fueron integradas de manera mixta, por varias personas que luego vivirían allí, y dirigida por mujeres. les beneficiarios eran propuestos en las asambleas barriales y luego por orden de necesidad se elegían quienes quedaban".

${ }^{63}$ Lograrían este espacio físico, dentro del barrio proyectado por la organización, en el 2019 http://folweb.com.ar/nota/888/inauguracion_de_la casa_flores_guerreras/

${ }^{64} \mathrm{La}$ colega Tamara Oldani realizará en los años 2016 y 2017, un ASIS que titulará "Intentando pensar los procesos de Salud Colectiva Y Epidemiologia Critica, con un Movimiento Social del Conurbano"
} 
Fomento y la Unidad de Gestión Local, era de darle importancia a sus pedidos pero siempre respetando el orden de llegada en relación a otras personas, por lo cual a veces debían esperar una o dos semanas para obtener mi informe, lo cual a veces no correspondía con los tiempos políticos, o cómo me diría el colega José Scelsio (se desempeñaba en la coordinación de un área de Desarrollo): "Luciano, hay gente a la que no podés hacer esperar".

José, oficiaría para mí en esos primeros años en Varela, como un referente y un respaldo. En continuidad con todo el apoyo que siempre me había brindado, primero como profesor en la carrera de grado y luego siendo mi jefe en la beca de la Secretaría de Extensión en la Facultad de Trabajo Social. Gracias a él, pude presentar mi currículum e ingresar en Varela y concursar en el Comité Contra la Tortura. En Varela, me contaría luego de mi ingreso en el 2005 que había salido de respaldo mío y le había garantizado a la coordinación de la Secretaría que yo no "armaría quilombo". Aparentemente, alguna colega que me conocía de la facultad le había advertido a la coordinación de Desarrollo Social de que yo era una persona políticamente conflictiva por eso fue fundamental el apoyo de José para que me contrataran.

Si Tania significó para mí conocer las mejores tradiciones de la Iglesia Católica, con José empecé a conocer la complejidad de la municipalidad y de la profesión, con la tranquilidad de sentirme acompañado en un trabajo, que al menos en sus inicios me resultó muy solitario.

Otro inconveniente que se me presentaba para asistir al nuevo asentamiento y a las reuniones por fuera de lo pautado por la secretaría de Desarrollo Social, era la posibilidad de que pasara por la salita el personal de la oficina de Recursos Humanos del municipio, quienes controlaban la asistencia y me pusiera ausente por no estar físicamente (más allá de mi firma). Esta modalidad del municipio se endurecía en periodos de lucha gremial por pedidos de aumentos salariales, siendo una forma de reprimenda hacia los profesionales agremiados en primer lugar $\mathrm{y}$ en segundo lugar al resto de los profesionales. Un ausente implicaba la pérdida del presentismo e incluso, como me pasaría unos años después, un sumario por abandono de tareas debiendo presentarme a declarar acompañado por el abogado de la CICOP (gremio de los profesionales de la salud). Mi decisión de priorizar al nuevo asentamiento, presentaba varios obstáculos como los que acabo de describir y otros que irían surgiendo obligándome a ser cuidadoso en cada intervención que hiciera.

En la visita del 14 de abril por sugerencia de Lorena les entregamos a los referentes de la toma la copia del expediente del asentamiento 9 de mayo y nos dividimos para hablar con las personas. Mary inmediatamente se puso a conversar con una chica de 15 años embarazada y la rescató dándole un turno para la obstétrica en la salita. Este término, se utilizaba en la salita cuando una paciente, generalmente embarazadas y niños menores de dos años, no concurría a 
los controles médicos pautados, entonces se enviaba a los promotores de salud, Mary en este caso, a rescatarla. Por mi parte me puse a charlar con dos chicas que las conocía desde hacía años, estaban en una de las treinta carpas instaladas en la vereda. En realidad, decir carpa no condecía con las rudimentarias y frágiles instalaciones de nylon y palos que oscilaban con el viento y la lluvia. Me contaron que estaban en la vereda "para evitar un juicio por usurpación" y agregaron que al hermano de un chico de ahí no le dieron las salidas transitorias de la cárcel porque le figuraba una causa por usurpación (que databa del 2002) por la toma del asentamiento 9 de mayo. Me entrevisté en ese momento con aquel chico y quedamos que desde el Comité Contra la Tortura le íbamos a presentar un escrito judicial para su hermano diciendo que la causa estaba caduca. Esta intervención, donde inevitablemente se mezclaban mis dos trabajos, no era la primera, ya que en la salita solía ver a familiares de detenidos, lo que en futuras ocasiones me traería dificultades para seguir visitando el nuevo asentamiento. Antes de retornar a la salita hablé con otras dos chicas con las cuales tenía un trato asiduo por diferentes intervenciones, La Polaca y Ana Ayala. Ellas me dijeron que había problemas entre Ariel y Emilio, que el primero hacía todo lo que decía el abogado Robles y el segundo quería meterse ya en los terrenos e "ir al choque".

Aún seguían en la vereda.

\section{Formar un campamento indio: entre las promesas, la fragmentación y la soledad del invierno.}

Desde los inicios de la toma Emilio solía pasar por la salita una vez por semana, generalmente para contarme cómo iban avanzando o hacerme pedidos puntuales como leche en polvo, ropa o bonos de mercadería. En esos días de abril pasó para dejarme una copia del acta de la reunión con el municipio y unos días después regresó con un pendrive en cuyo contenido había fotos de la toma y filmaciones en donde se veía al productor hortícola alambrar parte del predio. Además en el pendrive se encontraba en formato Word un poema, "para que vos lo tengas" me dijo.

Al día siguiente decidí visitar el nuevo asentamiento con Mary. Las caminatas con ella eran amenas, generalmente charlábamos de algunas situaciones del barrio o de cuestiones personales siempre con chistes y afecto. Recorrimos las once cuadras (desde la salita hasta la toma) cruzando la avenida Novak, tomamos la avenida Humahuaca y fuimos derecho, primero 
bordeamos la cancha de Defensa y Justicia y luego todo el asentamiento 9 de mayo ${ }^{65}$ y parte del barrio Santa Rosa, dado que la avenida Humahuaca separaba ambos barrios. Después de pasar los límites del 9 de mayo, caminamos unas cuadras que pertenecían al barrio Libertad. Aquí ya comenzaba a cambiar el paisaje de urbano a semirural e incluso antes de llegar a la toma se podía ver los invernaderos del horticultor. Al llegar al asentamiento pudimos ver que ya no se encontraban en la vereda y habían pasado finalmente a los terrenos. Ingresamos y nos encontramos con una delegada y luego con Nicole, quien había empezado a encargarse de las cuestiones de salud. Mientras hablábamos podíamos ver la disposición de las carpas en el terreno que formaban una $\mathrm{C}$ con una hilera en el medio. El "campamento indio" como lo llamaría Emilio, ocupaba menos de media hectárea y se encontraba rodeado por el alambrado que había colocado el dueño de la chacra vecina y los postes de madera que había puesto el dueño del club Cristal. Eran 34 carpas aproximadamente hechas de madera, nylon y lonas. Nicole nos comentó que recogían leña de los campos vecinos y que no tenían una comisión organizada para cocinar.

Nos separamos con Mary para poder hablar con más personas. La Polaca y Ana Ayala, junto a otra chica que prefirió no darme su nombre, me invitaron a pasar a su carpa. Hacía frío y estaba nublado. Se las veía tristes, ansiosas. Me contaron que "ya mataron a cinco víboras de las venenosas y que hay alacranes, que hace frío, que no saben qué va a pasar, que entre los referentes se siguen peleando, que esperan a los asistentes para el censo, que no hay criterios para sobre la gente que va a vivir ahí, que habian dicho familias y hay gente soltera desde el comienzo". ${ }^{66}$ Luego me dijeron que desde el municipio los querían trasladar a la zona rural del barrio Los Tronquitos como hicieron con otros asentamientos pero que nadie quería "tanto pelear para tener que irnos a un lugar donde no tenemos nada". Al salir de la carpa se podía sentir el aroma de los fogones, con las ollas de matecocido junto al olor de la basura quemada y el humo de los caños de escape de los patrulleros. Y el olor a tierra mojada presagiando la tormenta.

La situación que describían era grave: por un lado las diferencias entre Ariel y Emilio se iban profundizando, más que nada sobre si se metían en los terrenos o seguían esperando en la vereda y eso se traducía en incertidumbre. No estaban organizados en comisiones como en otras tomas

\footnotetext{
${ }^{65} \mathrm{E} 19$ de mayo comprendía como limites la calle 503 (la cancha del Defensa y Justicia estaba en la 501, las calles estaban numeradas cada dos números, 501, 503, 505, ) hasta la 509, sus otros limites eran la avenida Humahuaca y la calle 568 (el asentamiento comprendía la calle 568 , subiendo de a dos números; $570,572,574,576,578,580$ y luego la avenida Humahuaca)

${ }^{66}$ Lozano, Luciano. Cuaderno de campo del servicio social del Centro de Atención primaria La Esmeralda. Año 2011.
} 
(Merklen; 1997), tampoco estaban claros los criterios de permanencia y por otro lado el municipio no realizaba el censo acordado y además ofrecía un traslado a la zona de Los Tronquitos, a unos $17 \mathrm{~km}$ de allí, una zona predominantemente rural y aislada, algo impensado para las familias del asentamiento quienes eran mayormente changarines y cartoneros, por lo cual dependían de las redes que iban tejiendo en su territorio para conseguir trabajo y recursos. El planteo sobre los criterios de permanencia no me quedaba claro si era una exigencia del municipio o de las mismas personas de la toma. Emilio y Leonor me habían advertido que iba a ser "una toma de familias"; Robles en una disertación el día anterior en la Universidad de Quilmes había nombrado a 189 "familias". Al alejarme de la carpa de Ana Ayala, se acercó nuevamente Nicole y me planteó si yo podía "hacer algo" para que ella pudiera "tener un hijo a cargo" y aclaró que una vecina "se lo daría". Le expliqué la dificultad del pedido y me respondió que si no lo hacía la iban a echar. Agregó que el municipio ponía ese criterio: familias con hijos. Le propuse que planteara en la asamblea su situación y me respondió que así lo haría, que creía tener el apoyo de la gente, pero aun así tenía miedo. Era evidente la fuerza del criterio de ser una familia para permanecer en la toma.

Me despedí de Nicole deseándole suerte y me reuní con Mary para retornar a la salita. Antes de ello vimos a Emilio (quien no estaba cuando habíamos llegado) reprochándole a unos vecinos de su carpa que "pasaron lista y no me avisaron". Por lo que pude entender, pasaban una lista (con presentes y ausentes) diariamente como otro criterio de permanencia. Si bien en ese momento había 34 carpas que albergaban a 60 o 70 personas, todas las familias (o personas individualmente según cada situación) debían tener un representante que concurriera una vez al día a los terrenos y estar cuando pasaban lista.

La diferencias que se observaban, entre la desconfianza de la Polaca y Ana Ayala, Emilio, el miedo de Nicole, no se parecían a las visiones románticas de las personas resistiendo los embates del neoliberalismo ante su identidad amenazada (Merklen, 2005) se parecía más a los planteos de Lefebvre (1973) cuando advierte sobre la fragilidad de cierta "ideología del barrio" y de la importancia de visualizarlo como un espacio donde conviven las tramas significativas, redes de subsistencia y de conflicto de intereses.

Por otro lado era cierto que las personas que ocupaban esos terrenos tenían en su identidad algo común, la pertenencia a un mismo barrio, o mejor dicho a una zona de Florencio Varela.

En la conformación del asentamiento 7 de abril tenía preponderancia la trama sociocultural y la identidad ligada a la pertenencia barrial como ejes de donde partió el proceso de ocupación de un espacio territorial. En efecto, los referentes y las familias pertenecían a los barrios aledaños, se conocían y compartían espacios comunes. Emilio, Leonor, Rosario, Ana, vivían en 
el asentamiento 9 de mayo donde también alguno de ellos había participado de la toma de tierras en el 2002. Ana y la Polaca referían el temor por el traslado al barrio Los Tronquitos, ubicados en la zona rural del distrito. Allí con el traslado perderían sus redes sociales, sus vecinos, el mismo temor que tenía Rosario "que no le gustaría mudarse ya que acá conoce a los vecinos, que no hay problemas con la inseguridad, que los nenes pueden jugar en la calle tranquilos". ${ }^{67}$ Mary era habitante del asentamiento 9 de mayo, integrante del Centro Mugica y promotora de salud comunitaria del Centro de Salud La Esmeralda asistía cotidianamente al nuevo asentamiento para asesorarlos, brindarles alimentos, donaciones. Desde la parroquia Santa Teresa, el Centro de salud y de instituciones cercanas hubo ayuda parcial destinada a que la toma pudiera seguir su curso.

Los conflictos también se vivenciaban en la toma y en la red social, los criterios de expulsión para las personas que se drogaran o roben, la falta de organización, el desinterés y el individualismo atravesaban este proceso. En este sentido es interesante remarcar que en este momento de la toma aún las lógicas organizacionales de los asentamientos no podían institucionalizarse aquí ya que no había una adaptación territorial del típico modelo organizativo sindical de fábrica (Merklen 1997). Si bien había asambleas y delegados los mismos no eran vistos como trascendentes a la hora de decidir, solo se mencionaba a los dos referentes y al abogado. Es llamativo que no había una comisión para cocinar ni para los problemas de salud o educación, lo que Merklen (1997) llama comisiones especiales.

De las personas que ocupaban los terrenos muy pocas tenían trayectorias laborales donde hubiera experiencias organizativas sindicales. Mayormente subsistían por changas y/o planes sociales. El capital social y las redes sociales que podían llegar a tener eran, al decir de Bayón y Saraví (2006) redundante, habían perdido la capacidad de ofrecer lo que uno necesita "están todos en la misma" y esas mismas redes en los jóvenes podían ofrecer información donde realizar una changa o inscribirse en un plan social pero también podían introducirlos en actividades delictivas o evasivas (como el consumo de drogas). Los jóvenes que estaban ocupando los terrenos tenían trayectorias de precariedad (Bayón y Saraví 2006) donde a la privación de la pobreza estructural hay que agregarle la experiencia del desempleo, además de los periodos cada vez más largos entre changa y changa, junto con la incertidumbre de los ingresos y la desesperación de "no tener una moneda" ni siquiera para acceder a un empleo en otro lugar, ya que el costo del transporte era una barrera.

Según estos autores, Bayón y Saraví (2006) en el estudio que hicieron sobre Florencio Varela

\footnotetext{
${ }^{67}$ Ídem 4. Pág. 2
} 
la segregación espacial y la fragmentación urbana, la erosión del espacio público y el capital social comunitario, la incertidumbre e inestabilidad de las trayectorias laborales, los estigmas territoriales y la desconfianza en los canales tradicionales de la movilidad social son nuevos aspectos en una y otra de estas esferas que tienden a asociarse entre sí (...) esta tendencia a la acumulación de desventajas, cuya manifestación más evidente en la experiencia de los pobres es un entrampamiento en círculos de desventajas, plantea a la sociedad Argentina el riesgo de la fractura social y la experiencia cotidiana de una sociedad crecientemente fragmentada y desigual. (p.93)

La segregación espacial ${ }^{68}$ se agudizaba en el asentamiento 7 de abril y fue necesario desde las personas que ocupaban el predio configurar nuevas estrategias de supervivencia ante una realidad habitacional donde no había ningún tipo de servicios básicos y donde se convivía con nuevos y viejos vecinos pero con nuevas reglas en un marco de incertidumbre ante el futuro inmediato.

Frente a esta situación, a partir de los referentes y las organizaciones que apoyaban el asentamiento mediante negociaciones y sus acervos particulares de conocimiento se delinearon estrategias colectivas. Estas se enmarcaban en el conflicto y las negociaciones con el Estado.

Ese día, antes de irnos, Emilio nos contó que habían tenido una reunión en el municipio y habían solicitado el tráiler de salud. Luego refirió cierto malestar con Ariel pero no quiso explicarnos las razones. Con Mary le remarcamos la importancia de la unidad y de no separarse entre los integrantes. Me miró y me dijo que pronto iría a verme con una copia del acta acuerdo de esa reunión.

Unos días después, el miércoles 4 de mayo, antes de ir a la Reunión de Red contra la violencia pasó a verme un vecino del asentamiento a contarme que el tráiler enviado por la Secretaría de Salud finalmente atendió en la parroquia Santa Teresa a los tres nuevos asentamientos de la zona aunque aparentemente no distribuyeron medicación ni recetas y sólo hicieron controles de salud a los niños. La presencia del tráiler, en un lugar u otro, sería un motivo de disputa al interior de la toma en esta ocasión que haya ido a la parroquia Santa Teresa fortalecía al Encuentro Territorial donde confluían la parroquia (Tania y los curas) con el Centro Mugica (el abogado Robles) y Ariel, en su proceso de acercamiento a este espacio. Por otro lado Emilio, como se verá más adelante, hará alianza con otros actores.

\footnotetext{
${ }^{68}$ Tomo a Harvey (1997) que parte de la premisa de que la accesibilidad y proximidad son los rasgos más importantes de todo sistema urbano, siendo dos variables centrales para analizar los procesos de segregación. Hay una disputa de grupos sociales sobre la renta real, o sea el acceso al consumo de bienes colectivos o calidad de vida.
} 
Los días siguientes en la salita intenté ponerme al día con el trabajo acumulado: informes sociales, encuestas por diversos recursos, visitas por situaciones graves (violencia familiar, consumo problemático de sustancias, entre otros) y el fortalecimiento de La Red contra la Violencia invitando a nuevas instituciones. El lunes 9 de mayo visitamos con las residentes de salud mental a Bibiana, integrante de la Capilla Santos Mártires del barrio Santa Rosa. Bibiana tenía un pequeño comedor que funcionaba en la capilla y ella, en algunas de las visitas que me hacía en la salita por diferentes situaciones, también me había pedido reunirnos. En la reunión que tuvimos en su casa, Bibiana nos contó que CARITAS y la Fundación Novak le pidieron que debía cambiar la modalidad del comedor "incorporando algo más" con el aporte de una profesora y de un psicoterapéutico. Este pedido, nos dijo, se enmarcaba en los cambios organizacionales de la iglesia, con la división que había ocurrido en el año 2010 donde todo lo diocesano $^{69}$ quedaba bajo la órbita de la estructura eclesiástica y "el resto" lo manejarían las organizaciones sociales. En ese pedido, también le habían solicitado que comenzara a conectarse con el asistente social del barrio. La invitamos a participar de la Red Contra la Violencia y quedamos en armar junto a las residentes de salud mental un espacio de juegoteca, cuando se incorporaran los profesionales.

En esos días visité el asentamiento 9 de mayo, pasé por la casilla de Emilio Saldivar y charlamos sobre la toma. Se lo notaba enojado, me dijo que estaban "cercados" por la gente del club y de la quinta. De los terrenos que originalmente habían pensado ocupar, más de la mitad habían sido tomados por el club y la quinta. Se sentía molesto con Robles por aconsejarle no ocupar los terrenos de una vez; Emilio opinaba que "ahora perdimos mucho, para mi hay que ir de frente y mandarse, yo soy piquetero y voy a morir piquetero". Me aclaró que no acordaba con Robles pero que no se iba a pelear porque en ese momento no convenía pelearse con nadie. Emilio, por primera vez, comenzó a mencionarme los contactos que tenía. En el municipio se vinculaba a un funcionario, Víctor Mereles, coordinador de cooperativas, quien le arreglaba las reuniones cuando se lo pedía. A éste lo conocía desde el año 2010 cuando siendo integrante de la ATV, acampaba con el "viejo Walter" en la rambla frente al municipio y habían negociado con él que se presentaba como un intermediario ${ }^{70}$.

\footnotetext{
${ }^{69}$ Por diocesano se refería a la organización interna de las parroquias y capillas, quedando por "fuera" la relación con organizaciones sociales y el trabajo territorial.

${ }^{70}$ Declaraciones de Walter López (ATV) en diario Varela al día. 6/05/2010. "Víctor es un intermediario del municipio. Es un municipal. Con Victor nos veníamos reuniendo en distintas calles de Varela, para no llamar la atención. Hoy acá, mañana por allá. Íbamos acordando propuestas. Entonces Víctor nos dijo ayer (por el martes) que el Secretario de Gobierno, la subsecretaria de Gobierno y el Secretario de Salud, nos esperaban hoy (por ayer) en la municipalidad para acordar" http://www.varelaaldia.com.ar/archivo/levantaron-campamentopiquetero
} 
El "viejo Walter" era el referente de la ATV y años anteriores ambos eran parte del MTR de Martino, del "grupo de choque y custodia" aclaraba Emilio y advertía sobre otros contactos " $a$ mi me vienen a buscar de todos lados Luciano, ahora vinieron de Quebracho porque se armar las molos y la casera, también del municipio y con Martino puedo volver".

Luego Emilio me refirió las diferencias con Ariel y Robles: "este (por Robles) dice que ya tengo casa, no sabe nada, esta casilla es alquilada, cuando hagan el censo va a saltar". "Además lo del tráiler fue una cagada, iba a estar en las puertas del club Cristal y lo termino mandando como a diez cuadras en la parroquia de Santa Teresa, dijo que era porque el del club es un puntero, pero a mi qué me importa, lo importante es que iba a estar cerca". La importancia del censo para discernir entre las personas que tenían casa o no resultaría fundamental para la permanencia de Emilio y Leonor en el lugar. En tanto su crítica que llevaran el tráiler de salud a la parroquia Santa Teresa, puede leerse por un lado por la distancia (unos $500 \mathrm{mts}$ ) en tanto el club estaba a $100 \mathrm{mts}$ y, por otro lado, por sus diferencias con Ariel y Robles, ambos integrantes del Encuentro Territorial. Lo que en esa ocasión no me dijo Emilio es que se conocía desde hacía años con el puntero del Club Cristal y éste era un referente territorial del PJ que articulaba con su conocido en la municipalidad, Víctor Mereles.

Mientras hablamos, dos de los hijos de Emilio, menores de 5 años, jugaban semidesnudos sin zapatillas en el patio. Era un día frío.

Las diferencias entre los referentes, la agudización del conflicto entre las personas del 7 de abril con el horticultor y el Club, irían agravando la situación ante la falta de asistencia por parte del Estado municipal y el censo, cuyos resultados marginaría a los "avivados que ya tenían casa".

\section{EI censo y el agravamiento de las diferencias entre Ariel y Emilio.}

Finalmente, unos días después se organizó el censo para relevar el nuevo asentamiento. Para ello convocaron desde la Secretaría de Desarrollo Social solo a los promotores luego de mi negativa y la de varios colegas. Que mi jefa no haya insistido para que lo haga me alivió, dado que si lo hacía temía quedar implicado en los resultados (entendiendo que marginaría personas dejandolas fuera de la posibilidad de conseguir una casa) y en consecuencia los conflictos que se abrirían con la gente del barrio y los actores de la toma. Mary Herrera me dio una copia de la llamada "encuesta asentamiento" y me dijo que por cada encuesta debía hacer una visita domiciliaria y verificar que no fueran propietarios "porque hay muchos avivados que buscan terrenos para vender". Esta frase de Mary me sorprendió, ya que ella no solía hacer esos 
comentarios y me hizo pensar en cómo habría sido la reunión de capacitación que habían tenido las promotoras en Desarrollo Social.

La denominada "encuesta asentamiento" había sido confeccionada por un trabajador social del equipo de coordinación de la Secretaría de Salud y Desarrollo Social. La misma constaba de una carilla donde figuraban cuatro ejes a desarrollar.

\section{- Datos de los adultos responsables de la unidad familiar}

Nombres completos, nacionalidad, nivel de instrucción, edad y teléfono.

\section{- Datos del domicilio originario (previo al asentamiento)}

Aquí se indagaba sobre la ubicación del hogar anterior, los dueños de tal propiedad (padres, amigos, vecinos, alquiler, otros) la situación dominial del mismo (boleto c/v, escritura, cedido, prestado, ocupados, otros) tiempo de permanencia en el lugar y su inicio en la regularización dominial.

\section{- Diagnostico ambiental. Vivienda. Convivientes.}

Se preguntaba sobre el material de la vivienda (casilla de madera, mixta, de cartón, chapa, otros) sobre los servicios (cloacas, agua corriente, red de gas, baño interno) cantidad de ambientes y número de dormitorios.

En el punto convivientes se indagaba sobre la cantidad de personas y si había colecho ${ }^{71}$. Sobre cada persona se preguntaba su edad, vínculo, discapacidad y los programas sociales que accedían cada una.

- Cobertura de programas sociales para los adultos responsables de la unidad familiar.

Nómina de programas, "Programa Social para complemento alimentario Varela Incluye”, "Plan Más Vida", "Programa Argentina trabaja”, "Asignación Universal por Hijo para protección social”, otros, ninguno, trabajo en blanco.

En un recuadro separado "condición de riesgo". Por último, se pedía la firma y aclaración del informante y del encuestador.

\footnotetext{
${ }^{71} \mathrm{El}$ colecho es una práctica en la que bebés o niños pequeños duermen con uno o los dos progenitores. Es una práctica extendida en nuestro país, aunque hay debates sobre los riesgos que implican para el niño. Al respecto véase http://www.ms.gba.gov.ar/sitios/regionsanitaria8/bebes-seguros-las-8-medidas-preventivas-de-la-muerteinesperada-del-lactante-durante-el-sueno/
} 
La encuesta estaba orientada para detectar grupos familiares oriundos de la ciudad que no tuvieran otra propiedad. La condición de riesgo se evaluaba en el cuarto eje y era producto de los cuatro ejes en total. La sistematización de los resultados quedaba bajo la responsabilidad de la Secretaría de Desarrollo Social y de aquí se desprendería qué persona reunía los criterios de permanencia.

El miércoles 22/06/2011 mientras estaba atendiendo, se acercaron Emilio y Leonor. Para ese momento ya habían pasado dos meses y medio desde la primera vez que vinieron juntos a anunciarme que iban a tomar unos terrenos. Finalmente, las diferencias entre Emilio y Ariel se habían agravado. Me dijeron que el reclamo se había dividido, por un lado, ellos con las 34 familias asentadas en los terrenos y por otro lado Robles y Ariel con el listado restante con 135 familias. Emilio y Leonor habían tenido una reunión con la subsecretaria de gobierno Mariana Corrales y les había prometido que para las familias asentadas iba a haber una solución: o las mandaban a La Colorada o a Los Tronquitos (zona rural). Les respondí que eso haría que pierdan sus lugares de pertenencia, la escuela, la salita. Emilio me dijo que si no le daban respuesta iba a organizar con la ATV y el MTR un acampe en el municipio y me entregó unos planos de la zona en disputa.

Aquí ya comenzaba a quedar más claro cuál era la estrategia de algunos funcionarios del municipio (Mereles, Corrales y en el barrio Mauro Mendoza), coordinar con Emilio, dividir la organización e insistir con el traslado a la zona rural de las familias. División que se lograba por el ofrecimiento de unos pocos lotes y con la promesa ambigua de una solución para las personas que estaban asentadas y no para el resto del listado. Cuando se retiraron llamé al municipio para exigir los datos del relevamiento del PROMEBA del cual había participado en el 2010 y los resultados del censo en el asentamiento. Me respondieron que siga esperando y que ya me iban a llamar.

Luego atendí a Micaela Salazar, una mujer del barrio Santa Rosa, preocupada por la tarjeta de alimentos para su hijo que tenía diagnóstico de celiaquía. Al preguntarme el porqué de "tantas vueltas" y formularios para completar le expliqué el sentido de la encuesta social como “instrumento de control social" y "certificado de pobreza". Micaela se enojó y comenzó a insultar al municipio, al intendente. Ella no podía creerlo.

Ante las crecientes dificultades que iba adquiriendo el proceso de la toma, decidí espaciar mis visitas al 7 de abril, al menos por unos días. Al conflicto entre los referentes se le sumaba la insistencia del horticultor y del club por los mismos terrenos, lo que había llevado a un estancamiento de la resolución de la toma. 
Unos días después, el 27 de julio, vinieron a verme a la salita Emilio y Leonor. Me contaron que se habían reunido con Rosa Tedesco y Mariana Corrales quienes les habían prometido unas casas del Plan Federal de Viviendas. El viernes les entregarían a 30 personas las viviendas de ese plan. Emilio me aclaró que a él lo respetaban por haber estado en el movimiento y porque sabían que coordinaba con Mereles. Luego, me contó que Corrales le había propuesto trabajar juntos pero él no aceptó. Durante la charla, Leonor no hablaba, era Emilio quien llevaba el hilo de la conversación y ella asentía. Me contó que habían echado a Ariel porque "se robó los cables de luz" y que Robles era un excelente abogado pero no acordaba en cómo se manejaba con lo de las tierras. Mientras hablábamos, yo debía interrumpir la charla por numerosas consultas que me hacían otras personas a pesar de que ese día ya había atendido previamente a más de veinte personas. Emilio y Leonor entendían la situación y ni siquiera querían sentarse "para no quitarme tiempo".

Luego siguió insistiendo con diferenciarse de Ariel y me dijo que cuando empezó la toma desde el municipio le ofrecieron una casa para él sí "se corría" y que no aceptó; en cambio Ariel les dijo que sí. Sobre esto no les dije nada, se me hacía difícil responder algo frente a las acusaciones y por otro lado sabía que Ariel seguía vinculado a la toma.

Por último les pregunté si necesitaban algo, Leonor negó con la cabeza, Emilio me respondió que la dueña de la casilla (su casa del asentamiento 9 de mayo) se la había pedido pero él no se la había dado y que incluso tenía el apoyo de los vecinos para quedarse porque había echado a “los vagos y giles que se juntaban a drogar ahí". Luego me preguntó si tenía un bono para mercadería y algo de ropa. Le di ambas cosas y me agradeció agregando que me esperaba en su casa, que las puertas estaban siempre abiertas para mí.

Este encuentro con Emilio me dejó en claro que sus contactos con el municipio eran de cierto nivel de influencia dado que tanto Corrales como Tedesco no tenían cargos menores, sino que eran parte de la jerarquía alta municipal.

Por lo que pude ir reconstruyendo desde el municipio le había ofrecido a Emilio para terminar con la toma (personalmente o en las reuniones de negociación) lo siguiente:

- Algunos lotes en la zona rural. Pero este ofrecimiento era ambiguo, dado que habían dicho cinco lotes en la reunión para los tres asentamientos y luego a Emilio le ofrecieron mudar a las 34 familias que estaban con él.

- Casas del Plan Federal de Viviendas, lo cual me parecía muy difícil de cumplir, dado que el acceso a estas viviendas se realizaba previa inscripción, cruce de datos, entrevistas, selección de acuerdo a un score de riesgo. Y básicamente me parecía poco probable que el municipio premiara con casas a personas que hacían tomas de tierra. 
Lo cierto es que veía a la resolución de la toma más complicada. Mary me había dicho que un hombre había fallecido durante la toma por un paro cardíaco y que había rumores de la muerte de un bebé por hipotermia y aunque nunca pude acceder a datos certeros sobre ello $^{72}$, era evidente el riesgo que se corría en ese lugar.

En tanto, la ruptura con Ariel era clara y la acusación hacia éste (de robo y de buscar su beneficio), se repetía invariablemente en cada encuentro, así como la mención de que él en cambio era respetado por haber estado en el MTR. La diferencia fundamental entre Ariel y Emilio ya quedaba clara: mientras Ariel se iba va insertando en el Encuentro Territorial, espacio que le disputaba al municipio el control de los asentamientos y las redes territoriales, Emilio se iba insertando en las redes territoriales del municipio y el peronismo local.

\title{
4. Vicisitudes y peripecias de la intervención profesional.
}

En este contexto decidí visitar al asentamiento sin considerar que estaban los referentes distanciados, quienes además oficiaban de referentes para mi, con la población instalada en un campamento indio, compuesto por carpas de nylon y palos, en medio de un invierno crudo, vigilados por patrulleros, con instalaciones precarias de electricidad que generaban incendios, con pocos recursos y con miedo e incertidumbre. Lo hice sin pensarlo demasiado, sin hablarlo con mis colegas de la residencia y ni siquiera con Mary, entusiasmado y ansioso por mi labor en la maestría con mi cuaderno de campo.

A continuación, transcribo textualmente lo que escribí en mi cuaderno de campo ese mismo día:

\begin{abstract}
Extracto del cuaderno de campo. Jueves 14/07/11.Visita al 7 de abril
“Cerca del mediodía llego a la salita, antes había estado en una audiencia judicial en Quilmes propiciada por el Comité Contra la Tortura contra las unidades penitenciarias del complejo Varela por los problemas de salud y la mala atención médica. Estuve declarando una hora y media explicando nuestra postura al respecto.
\end{abstract}

\footnotetext{
${ }^{72}$ Sobre el hombre fallecido será su propia mujer quien lo confirme en una entrevista que le hicieron desde la residencia PRIM y luego publicada en YouTube, asimismo me lo confirmará Emilio y este agregará que para el entierro del bebé fallecido contó con la ayuda del presidente del club Mauro Mendoza. En tanto, en el informe del CELS "Derechos humanos en la argentina. Informe 2016" en el capítulo 2"Vulneraciones de derechos en tomas de tierra y asentamientos" (donde trabajan sobre el proceso del 7 de abril) confirman esta información a través de un testimonio de una de las personas ocupantes.
} 
Lorena y Pablo se habian ido a hacer visitas al asentamiento 9 de mayo y al barrio Santa Rosa por las pensiones asistenciales de Nación.

Decidi ir al nuevo asentamiento 7 de abril para charlar con la gente y los referentes. Decidí ir sólo dado que no sabía cómo estaba siendo el proceso actual y tenía comentarios de que habian quemado una carpa lo cual me generaba incertidumbre.

Fui caminando por la avenida Humahuaca, bordeando la cancha de Defensa y Justicia, esta avenida divide los barrios Santa Rosa de Libertad y dentro de Libertad está el asentamiento 9 de mayo. En el camino me detuvieron algunos vecinos para preguntarme sobre encuestas y la tarjeta Varela incluye que hace dos meses que no la cargan. Les respondo que de la tarjeta no sé nada, que llamo a desarrollo y no me dicen nada. Por las encuestas tienen que averiguar personalmente.

Llego a la toma, hay 2 chicos, uno de 16 años y la chica de 20, alrededor de un brasero, están calentando agua. Hace mucho frío. Enseguida aparecen tres personas más, adultas, hay uno que ubico por las visitas que hice los primeros días del asentamiento, tiene esquizofrenia y no está en control ni con medicación. En aquella ocasión le advertí lo peligroso que podía ser para él mismo. También surgen tres mujeres de otra carpa, me saludan pero se mantienen a distancia. De los tres adultos que se acercan a hablar conmigo está el de la esquizofrenia, otro que es el hijo de Rita Burgos (una señora que le hice hace tres años varias encuestas) y otro que está bien arreglado, con ropa deportiva. Hablamos sobre la toma, no saben qué está pasando, les pregunto por Saldivar, por Leonor y por Márquez, me dicen que no están más ahí, "que ahora están ellos". Refieren que se reúnen con Robles y que con él entran a la municipalidad, que sino no podrían ir a la puerta que ya los echarían. Cuentan que han echado a "los que se drogan y a los que molestan” que están cansados de estar así, que aparentemente les darian otros terrenos para instalarse, que acá no pueden plantar bien sus casas porque saben que deben irse y eso los perjudica, que hace poco se prendió fuego una carpa porque los cables son finos. Y que la policía les rompió el arco de futbol de la canchita que armaron "empezaron a girar como un trompo con el patrullero alrededor del arco hasta que lo chocaron" me explican, "estarían drogados" agregan. Mientras hablamos, un nene de 3 años juega con un carrito, el padre es el que tiene esquizofrenia, le advierte que deje de molestar, pero el nene sigue, a la 
tercera vez el hombre empieza a patear al carrito violentamente, el nene llora. La situación es tensa. Yo no los conozco y ellos a mí tampoco aunque saben dónde trabajo. No sé qué decir. Le pregunto por el tratamiento, apartándome para que el resto no escuche, a él no le importa eso y me responde en voz alta que aún no fue. El hijo de Rita Burgos comenta "a veces se pone loco, una noche empezó a patear todo, desarmó una carpa a patadas”, él sonríe afirmando. Parece que los demás le tienen miedo o respeto y todos esperan sus palabras para ver qué es lo que pueden decir.

El hijo de Rita Burgos me dice que nosotros le pifiamos al darle las cooperativas a los piqueteros, le pregunto a qué se refiere con nosotros, me contesta que a la municipalidad. Le contesto alterado y le digo que yo no soy la municipalidad, me responde que sí, que soy la municipalidad. Le aclaro que trabajo en la municipalidad, que es diferente, que no es lo mismo Pereyra que yo. No dice nada, sonrie. Me doy cuenta de que debería haber contestado de otra manera, pero no me importa, estoy harto de que me identifiquen con la municipalidad. Se crea un silencio incómodo.

"Robles hace rato que no viene, había mucho puterio" dice una mujer "nos dijo que nos teníamos que organizar nosotros y que él nos acompañaba”. Un chico que estaba callado empieza a gritar "ese Robles es un careta, se llena de plata con nosotros", tiene un lenguaje que me hace acordar a los chicos de la cárcel y al estereotipo sobre los chicos de barrio. La situación aún es peor, no sé qué hacer ni decir. Hay una llovizna fina. "Tiene la re casa en el centro, es un careta" dice y agita las manos. Pienso en algunas palabras, pero no se me ocurre nada, no soy parte de la organización de Robles como para defenderlo y tampoco acuerdo en que robe plata. La misma mujer que dijo lo de los puteríos le contesta "si roba o no, no lo sabes, lo único que sabes es que no nos conviene separarnos de él, porque así vamos a la municipalidad y nos escuchan”. Les pregunto sobre los trailers de salud, me dicen que han venido pero que no les dan medicación, que han logrado que Desarrollo Social les de mercadería, colchones y frazadas cada 15 días. Me parece increíble y eso me hace confirmar los dichos de otros vecinos indignados porque a ellos no les dan nada y "eso que no roban terrenos".

Les pregunto si necesitan algo de la salita, les comento que hay leche en polvo y tal vez les pueda armar un botiquín de nuevo, me dicen que si, les pido un teléfono 
y el chico de ropa deportiva me da el celular, se llama Mauro. Me despido con una sensación amarga.

Al llegar a la salita hablo con las enfermeras y me arman un botiquín. Agarro leche de administración. Le envío mensaje a Mauro y al rato llega en moto con el hijo de Rita Burgos. Están contentos con el botiquín, la leche y la ropa, agarran varias prendas para ellos, les digo que ya está, porque hay otra gente que necesita. Les pregunto sobre el botiquín, si saben usar las cosas, Mauro me dice que en la unidad le enseñaron, que en la unidad penal de Varela le enseñaron, que él trabaja ahí como guardia cárcel. “№ me ves la cara de ortiva?” agrega. Le digo que yo trabajo en el Comité Contra la Tortura, se sorprende y se tensiona. ¿No nos quieren eh? Le pregunto irónicamente. "corte que ustedes le creen todo a los presos eh" me responde. "Pasan cosas, ¿no? Igual yo trabajo más que nada en salud, con los pibes que se mueren de sida" le aclaro. Se sonrie y me mira. Se despiden de mí, antes de irse les pregunto por tercera vez si van a llevar las cosas al asentamiento. Quedo cansado y enojado. Tengo ganas de dejar todo, Varela, el Comité. Por lo pronto resuelvo no volver más al asentamiento hasta que me reúna con Robles y me ponga en situación.

Llegan Lorena y Pablo, les comento la situación, Lore me dice que estuve bien en decirle que era del Comité y que no necesariamente tenemos que intervenir en el asentamiento, que lo veamos".

De aquí se desprenden varios de mis errores en ese día en particular, por empezar, ir solo al asentamiento, sin avisar, sin coordinar con los referentes con los cuales estaba trabajando. Considero que active la moral sacrificial (Cazzaniga, 2016) y eso atentó contra mi rigurosidad profesional entre mi preocupación y mi necesidad de acompañar el proceso.

Otro error fue considerar que las tensiones de mi lugar de trabajo se resolverían por mi coordinación con los referentes y los delegados. Subestime la dimensión política (Cazzaniga, 2016) al no analizar la coyuntura para elaborar estrategias y no consideré las consecuencias de mi intervención; siguiendo a esta autora, el por qué debo desde la reflexión ética, en relación a las técnicas a usar “...por qué debo, en todo caso, realizar una visita domiciliaria o aplicar un cuestionario o seguir a rajatablas un protocolo; qué consecuencias hacia el otro/los otros de la intervención profesional traen tales elecciones o decisiones?" (Cazzaniga,2016, p.11). No me basé en mis años de experiencia, donde difícilmente podía desarmar el argumento de que los recursos dependían de mí, de que era un empleado del municipio y no el municipio. La complejidad era que por medio de los informes que yo hacía, las personas muchas veces 
accedían a los recursos, entonces ¿por qué no podrían pensar que efectivamente yo encarnaba al municipio y/o a posibilidad de obtener recursos? Mi responsabilidad profesional, como bien afirma Aquín (2012) para enfrentar los riesgos y desafíos del contexto actual implicaba “...ser responsable significa ser capaz, tener poder tanto de dar respuesta a la pregunta acerca de por qué de nuestras decisiones y acciones, como hacernos cargo de sus consecuencias". (Aquín N. et al, 2012, p. 308).

Además en situaciones extremas yo sabía que las personas se suelen desesperar, lo cual es lógico. El ejemplo del temporal de noviembre del 2007 había marcado mis años en Varela, dado que a las personas afectadas les habían dicho que para acceder a los recursos tenían que verme, y ellos habían ido a buscarme con enojo y desesperación para resolverlo. Ahora en ese día del 2011, me asociaban con los manejos de recursos del municipio en torno a las cooperativas.

Un punto interesante de estos párrafos es la acusación al referente (Robles) de robar, algo que escuche reiteradas veces en las entrevistas, sobre diferentes personas, sin importar su pertenencia política. Podría decir que es algo típico en nuestra sociedad, la acusación del político que roba. El agravante aquí es que era evidente mi coordinación con la organización a la cual pertenecía Robles, por lo cual entre las acusaciones de ser de la municipalidad y estar coordinando con alguien que roba mis posibilidades de intervención eran limitadas.

En tanto, era la primera vez que hablaba con personal del servicio penitenciario por fuera de la cárcel, donde el trato que teníamos solía ser muy respetuoso, aun sabiendo ellos que nosotros los denunciaríamos y nosotros sabiendo que ellos maltratarían a las personas detenidas que se animaban a denunciarlos. Ese día en particular había estado en una audiencia judicial denunciando las muertes en la cárcel, algo agotador. Cada muerte tenía un rostro para mí, un nombre, Sergio, Rosa, Camilo, una familia, un pedido de ayuda que había sido en vano, una historia que reconstruíamos con numerosos testimonios. Y ningún responsable generalmente, pese a las pruebas, a los testimonios.

Como mencioné anteriormente, los espacios donde me desempeñaba laboralmente tenían puntos en común y solían juntarse pero siempre del lado de los otros donde yo consideraba que asumía el compromiso ético político. En esta situación intenté utilizar los recursos del CAPS (exiguos, claro) para un botiquín y leche, fortaleciendo la idea que efectivamente ciertos recursos dependían de mí, por lo cual eso podría ser parte de futuros cuestionamientos o parte de la estrategia de fortalecer mi lugar en el proceso de la toma.

Ese día había comenzado con una audiencia judicial contra el sistema penitenciario y no pude evitar enfrentarme con una cara visible de ese sistema que denunciaba por la mañana. Quizás para las personas que visité ese día, yo era también una cara visible pero del Estado municipal. 


\section{Conclusión}

La usurpación de tierras por parte del horticultor y del club no tuvieron consecuencias para ellos, lo que sería en palabras de Robles (2011) la continuación de una vieja práctica donde se favorece a los medianos y grandes propietarios por parte del municipio en detrimento de las clases populares. Aquí el Estado no actuó ante la ocupación que realizaran éstos sobre los terrenos que previamente habían sido limpiados por las personas del asentamiento. Por el contrario, la presencia de la policía hostigando a las personas de la toma parecería que fuera para garantizar que el asentamiento no se ampliara.

La pérdida de esa extensión de tierra sería uno de los reproches que le haría Emilio a Robles y Ariel, responsabilizándolos por la demora en dejar la vereda y pasar a los terrenos. A esta diferencia entre los referentes se le agrega las disputas por recursos materiales y simbólicos (el tráiler, las promesas de viviendas, alimentos) y paulatinamente se fue conformando una pelea frente a frente, cuerpo a cuerpo, como afirma Svampa (2003) un escenario escindido entre adversarios políticos, entre el Encuentro Territorial y la Municipalidad. El recorrido de Emilio, su experiencia de militancia, su pertenencia barrial, las relaciones interpersonales explican, de algún modo, su elección en constituirse como referente del municipio y disputar con el Encuentro Territorial. Esto no debe ocultar la maniobra de funcionarios y operadores políticos del PJ en ahondar las diferencias para dividir el reclamo y la lucha de la toma.

En los pedidos que hacían ambos referentes y el resto de los ocupantes, tanto por los terrenos, mercadería o agua, apelaban a nociones legitimadoras de demandas (Thompson, 1995) y se valían de intervenciones históricas del Estado en lo referente a la posibilidad de obtenerlas. A diferencia de lo descripto por Manzano (2008) en este proceso no se articulaba el pedido con la demanda de trabajo. Es destacable la existencia de criterios compartidos para permanecer en la toma entre el municipio y la gente que ocupaba los terrenos. Estos criterios en común fueron resultado de como las políticas públicas se han hecho carne y son apropiadas en nuevos contextos. En este sentido se explica la legitimidad para que pudiera realizarse el censo dentro de los criterios de evaluación moral para separar a los avivados de los merecedores. Asimismo, siguiendo las reflexiones de Sigal (1981) en torno a la burocratización y desagregación de las reivindicaciones por parte del Estado, se puede ver cómo a través de la encuesta-asentamiento realizada por promotores de salud bajo las órdenes de la Secretaria de Salud y Desarrollo Social se comienza a desagregar la demanda colectiva: se individualiza a cada familia del listado, se la analiza desde el soporte digital-burocrático de la secretaría y desde el propio municipio en las oficinas de regularización dominial (quienes manejan la adjudicación para el Plan Federal 
de Viviendas) decidiendo qué grupo familiar es merecedor de un lote y no es un avivado que busca lucrar con los terrenos.

En este contexto, mi intervención profesional merece el análisis en varios aspectos, por un lado, la advertencia por parte de los referentes territoriales del PJ del barrio Esmeralda por mi preferencia hacia los asentamientos. Esto fue un llamado de atención hacia algo que ya sabía y que en el entusiasmo por estar en el proceso del 7 de abril había olvidado: para profundizar el trabajo atinente a problemáticas estructurales (como el acceso al hábitat) debía tener cubierto el trabajo asistencial y la presencia en todos los barrios, de modo que nadie pudiera cuestionar mi trabajo profesional y con ello mis decisiones políticas en torno a la prioridad de mis intervenciones. Por otro lado, este entusiasmo me llevó a que en plena fragmentación y soledad del invierno complicara mi lugar en el asentamiento cuando lo visité espontáneamente y discutí primero con personas que estaban desesperadas, angustiadas y con miedo y luego con el penitenciario en la salita. Esto llegó al punto de casi no poder sostener el vínculo con las familias que permanecían el campamento indio poniendo en crisis mi rol profesional y mi posibilidad de acceder al campo. Evidentemente, tener la pertenencia laboral por partida doble era más difícil de manejar de lo que creía trayéndome vicisitudes y peripecias que podían marginarme del proceso que consideraba prioritario analizar. Pero a pesar de esto, aún dispondría de una posibilidad para volver al campo y recomponer mi lugar profesional allí cuando las organizaciones de las redes de reciprocidad en las cuales me fui insertando darían un paso decisivo en pos de lograr una nueva toma. 


\section{CAPÍTULO 5}

\section{"PREPARATE, SE TE VA A AGRANDAR EL BARRIO"}

\section{Introducción}

En este capítulo desarrollaré las características del Centro de Participación Popular Carlos Mugica, integrante y fundador del Encuentro Territorial, en el contexto de la organización de la segunda toma del 7 de abril que consistió en el traslado a unos nuevos terrenos luego de meses de negociación con el municipio sin tener soluciones concretas. La figura del referente Pedro Robles será central para este proceso y junto a Tania me invitarán a la participación de la nueva toma. Esto me generará alegría pero también interrogantes y dudas sobre cuál sería mi aporte y los riesgos a los que podría exponerme.

\section{El Centro Mugica.}

Agosto lo comencé con problemas. Varias personas me habían comentado que las tarjetas de alimentos no estaban cargadas y me pedían un bono de mercadería. Esto me representaba una dificultad dado que sólo disponía de treinta bonos mensuales y solía reservarlos para las personas que no tenían tarjeta. Por otro lado, no podía derivarlos a Desarrollo Social porque allí les decían que ya figuraban con la tarjeta de alimentos y que volvieran a la salita a pedirme un bono. Realmente no sabía qué hacer, las situaciones eran numerosas y ameritaban asistencia pero los recursos eran cada vez más escasos. En tanto, me había enterado que varias personas ya estaban organizándose para ir a hacer un piquete en Desarrollo Social por la falta de carga de las tarjetas. La que lideraba el reclamo era Yésica (amiga de Mary) una mujer que solía atenderse en la salita. No era la primera vez que los vecinos organizaban un piquete. Desde mis primeros años en Varela me sorprendía como esta medida de lucha era utilizada, tanto por vecinos autoconvocados como por punteros del barrio Santa Rosa quienes llamaban a cortar la avenida cada vez que no había luz. Como afirma Manzano (2008) el piquete se configuró en una forma legítima de demandar cosas al Estado utilizada por diferentes actores de las clases populares. Y generalmente estas medidas tenían una respuesta inmediata del municipio.

Unos días después, el lunes 8 de agosto tuve atención en la salita, luego de ver a varias personas se acercó Mary. Ella me comentó que aparentemente habría una respuesta desde el municipio para las personas de la toma del 7 de abril, solamente para las que estaban en las carpas que involucraba a unas 30 familias y no para el resto del listado. La propuesta contemplaba la 
entrega de unos cinco lotes en el barrio Los Pilares, en la zona rural del distrito y muy alejado del barrio. La oferta era insuficiente para resolver la demanda dado que el municipio ofrecía esos únicos lotes para los tres asentamientos (Villa Argentina, Santa Teresa, 7 de abril). Esta misma propuesta fue la que me había comentado Emilio unos días atrás como parte del logro de sus negociaciones con los funcionarios municipales. Para Mary, Emilio no estaba bien "de la cabeza", había amenazado a Robles mandándole a decir por medio de ella de que "no se metiera más en el asentamiento" y que él estaba con Mereles. Mary le respondió que vaya él mismo a decírselo. En estas situaciones, cuando relataba momentos tensos Mary solía reírse. Luego, bajando el tono de voz, me dijo que desde el Centro Mugica y otros asentamientos realizarían una toma muy grande en la avenida Humahuaca al fondo. Para esta toma iban a reunir a referentes de otros asentamientos y a los curas. Todavía no sabían cuando pero evaluaban que el proceso de negociación en la mesa de gestión del municipio estaba agotado. Finalmente, el Encuentro Territorial intentaría buscar por su propia cuenta la solución para los asentamientos.

Este espacio venía creciendo en el distrito y ese año particularmente había tenido una mayor visibilidad tanto así que el Diario Popular en su sección Quilmeño le dedicó (a mediados de abril) un artículo completo sobre el "Quinto Encuentro de Tierra, Vivienda y Hábitat" realizado en la sede del barrio Villa Argentina del Centro Mugica. El artículo destacaba la participación de aproximadamente cien delegados de asentamientos además de la parroquia Santa Teresa, San Cayetano, el Departamento de Justicia y Paz del Obispado de Quilmes. En ese momento el Encuentro Territorial Para Todos y Todas tenía cinco años de antigüedad desde que había sido fundado por el Centro Mugica y la parroquia Santa Teresa. En cada encuentro se compartían experiencias, aprendizajes, logros, además de hacer comunicados de solidaridad activa con los nuevos asentamientos y exigir la declaración de emergencia habitacional del distrito. En este encuentro también habían participado Mary, Tania y Ariel. Este último integraba el Encuentro Territorial desde los primeros días de la toma del 7 de abril.

El abogado, como solían llamarlo muchas personas a Pedro Robles, era la figura más conocida y representativa del Centro Mugica. Su presencia en jornadas, foros, reuniones en algún barrio, en el municipio, o en entrevistas para diferentes medios era siempre solicitada, lo cual no significaba que concurriera él mismo, dado que como organización, según me referiría en la entrevista, apostaban a que sus integrantes tuvieran experiencias en diferentes espacios. Pero Robles también sabía que para determinados eventos era él el indicado para concurrir debido a su capacidad de oratoria, su templanza y además el hecho de que parte de su tarea en el Centro Mugica era la de coordinar con otros actores sociales. En este sentido, su presencia en el "Foro- 
Debate: tierra, vivienda y hábitat" en la Universidad de Quilmes, organizado por CARITAS de Quilmes a fines de abril, se había inscripto en este marco. Robles sabía la importancia de por un lado fortalecer los vínculos de la organización con sectores del propio Obispado de Quilmes (e incluso funcionarios de diversas agencias del Estado) y por otro lado, utilizar el foro convocado en el contexto de la lucha por la sanción de la Ley de Hábitat Social ${ }^{73}$ para denunciar la situación de los asentamientos de la zona y la política de viviendas. Por ello, los diferentes funcionarios y representantes de instituciones debieron escuchar la voz firme, pausada y grave de Robles decir en primer término que a los funcionarios municipales les molestaba que su organización trajera gente del barrio a la mesa de negociaciones. Luego continuó con una descripción de la problemática en el distrito:

"Florencio Varela tiene, según el Censo del 2001 una población de 390.163 habitantes, de los cuales 27.134 viven en asentamientos, son 273 hectáreas. Según el Censo 2006 hay 43 asentamientos (a los que se agrega San Cayetano con 340 familias; Agustín Ramírez con 70 familias, 7 de abril con 189 familias, Nuevo Santa Teresa con 120 familias, Nueva Villa Argentina con 169 familias). De las 19,000 hectáreas del distrito el 1,44\% está ocupado por villas y asentamientos.

- En Florencio Varela se construyeron más de 4.000 viviendas entre 2006-2011 en grandes complejos 1.800 viviendas en Barrio Santa Rosa.

- Se inauguraron escuelas y salas de primeros auxilios en zonas contaminadas como Las Margaritas y El Molino.

- No se adjudica por cercanía al lugar donde tienen las redes sociales.

- No se tiene en cuenta el tipo de trabajo que realizan (cartoneros)

- Pésima calidad de las construcciones, se tuvo que refaccionar de nuevo El Molino

- Falta de transparencia en la adjudicación.

- 25 mil familias se hallan en lista de espera.

- No se construye en los asentamientos sino en nuevos barrios.

- La corrupción en la obra pública explica que se privilegie los complejos habitacionales al lote con servicio.

\footnotetext{
${ }^{73}$ La Ley 14.449 de Acceso Justo al Hábitat fue sancionada el 29 de noviembre de 2012 y publicada en el Boletín Oficial en octubre de 2013.
} 
- Las empresas constructoras, realizan obras subcontratando a las cooperativas para evitar la responsabilidad laboral."

En el cuadro de situación descripto por Robles se podía dimensionar la gravedad del problema habitacional de Florencio Varela, la cantidad de asentamientos y las políticas públicas que existían al respecto. Sobre el 7 de abril, Robles contaba las 189 familias que figuraban anotadas, no solamente a las treinta que ya estaban instaladas en los terrenos.

Tanto el Centro Mugica como la parroquia Santa Teresa coincidían en la importancia de concurrir a las mesas de diálogo con el municipio para resolver la problemática de los asentamientos, sin embargo varios meses después, ambas organizaciones ya no confiaban en que hubiera una solución. Por eso, el 22 de junio enviaron una carta al intendente donde resumían la situación de los asentamientos, las reuniones con los funcionarios, las promesas que habían recibido y la falta de respuestas, advirtiendo finalmente que si se producía alguna muerte de las personas de la toma el único responsable sería el propio intendente. Esta carta tampoco había tenido respuesta, por lo cual un mes después realizaron un folleto que distribuyeron en diferentes puntos de Varela. La nota titulada "Nosotros también tenemos derechos" tomaba el mismo contenido de la carta al intendente. Era el preámbulo de la clausura de las negociaciones con el municipio.

Por este motivo, luego de la charla con Mary en la salita, pasó Tania y me comentó lo mismo: "una toma muy grande en los terrenos del fondo de Humahuaca". Me dijo que querían prever todo porque tenían ciertos temores, entre ellos el invierno, un temporal y la sospecha de: "puede haber caos". Me invitó a participar de la misma sabiendo de los límites que tenía yo como trabajador social. Le respondí que obviamente quería participar pero armando una estrategia con Robles. Tania ya había previsto este pedido y me dijo que para el viernes 19 de agosto estaba pautada la reunión. Mi preocupación era la de no quedar como el "fusible" para Desarrollo Social y ante cualquier tensión pagar el costo, quedando como el responsable de lo que fuera, como me había pasado numerosas veces. Mi jefa me había dicho que debía ser el intermediario entre las personas del asentamiento y la Secretaría, lo cual llevaba a exponerme en dos lugares. Le dije a Tania que mi aporte y el de las residentes podía ser desde lo sanitario, tratando que las familias que tenían hijos siguieran atendiéndose en los centros de salud, haciendo vínculo con promotores de salud, colegas comprometidos y por otro lado, podríamos revalidar el diagnóstico sobre las necesidades que hicieran las organizaciones con nuestra firma. Tania me contó de las reuniones con los funcionarios municipales y que las negociaciones estaban trabadas. 
Finalmente pasado unos días nos reunimos en la casa de Mary. A Robles no lo conocía personalmente, en las diferentes reuniones que habíamos tenido tanto por la Red Contra la Violencia o en la mesa distrital había presencia de su organización pero representada por otras personas, mujeres generalmente. Esto mismo sucedía con cada tema en el cual coordinábamos: trabajo por situaciones de violencia familiar grave, migrantes que requerían asesoramiento, entrega de eximición de tasa migratoria con mi firma para que ellos la completen. Teníamos mutua confianza pero apenas habíamos hablado por teléfono años atrás. Sólo una vez, Mary, en medio de una reunión me había dado su celular para que hable con él. En esa ocasión, desde La Red se había proyectado un taller acerca de la crianza de los niños en la Copa de leche de Mary para trabajar con las familias del asentamiento, desde una perspectiva que no incluyera los golpes. Esta campaña que habíamos iniciado en la Red, se titulaba Chau Palmazo siguiendo una propuesta de Norberto García (trabajador social de la Escuela $n^{\circ} 20$ ) quien además había traído material para socializar y sería el coordinador de los talleres. Norberto tenía 50 años y solía referir su trabajo en una ONG que acompañaban a adolescentes en situación de vulnerabilidad social "en el armado de un proyecto de vida autónomo", en palabras de él. Además, contaba su trabajo en el Consejo Local de Niñez de Almirante Brown, donde luego de ser amenazado, había renunciado. Desde la Red estábamos entusiasmados con el proyecto pero un día antes de su implementación, Mary en plena reunión de la Red, angustiada y sin dar explicaciones, dijo que el proyecto no se podía hacer en la Copa de Leche. Norberto, visiblemente contrariado al principio, preguntó el porqué; Mary respondió que no se podía. Norberto sonrió y respondió que no había problema, que lo podíamos hacer en la escuela. A la salida de la reunión, varias integrantes de los gabinetes de las escuelas se acercaron a plantearme su enojo por la situación e incluso me advirtieron que iban a evaluar la continuidad en La Red y se retiraron. Fue entonces cuando Mary me pasó su teléfono celular: "Luciano, querido, te habla Pedro Robles ¿cómo estás? Un gusto hablar con vos. Mira, ese tipo Norberto García, y a trabajó con nosotros y es un jodido ¿me entendes? Bueno, querido, un abrazo”. Finalmente, el proyecto se desarrolló en varias escuelas.

\section{2. "Preparate Luciano vas a tener un área más grande"}

Con el recuerdo de esa única conversación con Robles, Mary me recibió en su casa. Al ingresar saludé a Tania, la radio estaba encendida y no había demasiado luz, de una de las sillas se incorporó una persona enorme que sonriendo me saludó con un abrazo, era Robles. Pedro era alto, fornido, de ojos claros, con el pelo y la barba encanecida casi blanca aunque tenía 44 años. Con sus palabras, sus gestos, la sencillez de su vestimenta y la atención que prestaba cuando 
alguien hablaba trasmitía comodidad y confianza. Así me sentí esa vez. Mary preparó unos mates mientras hablábamos, en la radio se comenzó a escuchar "Pereyra está muy grave, tiene una enfermedad desconocida". Nos miramos sorprendidos, Robles nos dijo que muchas veces se hablaba de lo mal que estaba Pereyra y que incluso circulaban leyendas sobre cómo continuaba con vida pese a los problemas de salud que tenía.

Luego, Robles comenzó a explicarme el trabajo de acompañamientos a migrantes desde el Centro Mugica: la encargada Nelly era la persona que pasaba por la salita a buscar las eximiciones para tasa migratoria que yo les dejaba firmadas. Ella, agregó Pedro, era hermana de un detenido desaparecido y formaba parte de la lucha que estaban dando para establecer las complicidades que hubo en Florencio Varela con la dictadura en plena democracia cuando varios funcionarios se negaron a investigar cuerpos enterrados como NN. Otro tema en el que trabajaban mucho era el de atención a mujeres víctimas de violencia, a las cuales asesoraban legalmente y acompañában a realizar las denuncias.

Mary contó que Santinon (Directora General de Desarrollo Urbano y Vivienda de la Municipalidad) la había llamado para avisarle que ese día iban a medir los terrenos del 9 de mayo para comenzar a regularizarlos. Para Robles en la municipalidad "tienen conciencia de que el problema de la tierra va a estallar y como no tienen políticas, embarullan”. Además, se había enterado de la conformación de una "unidad de gestión política" donde "se juntan funcionarios y punteros, acá en el barrio Libertad está la Huanca, el Nafta Grieves y algunos del PJ'.

Lo de embarullar, sería para Robles la explicación del accionar del PJ en el barrio, afirmando que si el PJ no controlaba el proceso, lo boicoteaban mediante operadores que influían sobre las personas que estaban tomando con el objetivo de dividir la organización. Robles no sólo conocía como actuaba el PJ en el barrio, sino que era un estratega siempre dispuesto a sumar personas comprometidas en cada tema que el Centro Mugica trabajaba. Ese día en lo de Mary, me pidió si se podían conseguir los datos del relevamiento del PROMEBA ${ }^{74}$ donde yo había participado como encuestador. Agregó que mi colega Claudia Muñoz de Toro tenía un CD con datos, aunque faltaban otros más. Quedamos en que me contactaría con Claudia y le pediría el CD para hacer una copia y alcanzársela a Mary. En tanto, por otro lado, le pediría a mi jefa formalmente que los consiga directamente de Santinon. El pedido, me pareció extraño, con Claudia éramos amigos y eso era algo que Robles no podría desconocer; y además ella era una

\footnotetext{
${ }^{74}$ En Florencio Varela se desarrollaron varios proyectos del PROMEBA (barrio La sirena, Don José, entre otros) en el que participé como encuestador fue en el de Santa Teresa que contemplaba los asentamientos de la zona.
} 
integrante del Centro Mugica. Supuse que Pedro deseaba hacerme sentir parte de la organización al ofrecerme una tarea. Sobre los datos pedidos a mi jefa, ésta se los pidió a Santinon y los primeros días de septiembre me pasó por correo electrónico el documento. Unas semanas más tarde, en un diario de Varela, en primera plana, Robles denunciaría con estos datos remarcando que eran oficiales, las malas condiciones de vida de la población de estos barrios. Ya finalizando la reunión les comenté, especialmente a Robles (dado que Mary y Tania ya lo sabían) que estaba cursando la Maestría en Ciencias Sociales, de mi intención de investigar las tomas de tierra y que estaba escribiendo un cuaderno de campo sobre mi trabajo. Además les referí mi fascinación sobre algunas autoras como Cristina Cravino. Robles me preguntó si se podría organizar un encuentro con Cravino y personas que hayan transitado otras experiencias de toma de tierra para intercambiar opiniones. Le respondí que lo veía posible y que lo podíamos organizar en la facultad de Trabajo Social de La Plata ${ }^{75}$.

Antes de irme se miraron entre ellos y Robles me hizo el anuncio "Preparate Luciano vas a tener el área más grande". Sonrieron y me contaron que desde el Encuentro Territorial iban a realizar una nueva toma para trasladar el 7 de abril a otros terrenos, cercanos de allí, pero sin los problemas que tenían. Era la primera vez que desde este espacio organizaban una toma, aunque el Centro Mugica ya había organizado y acompañado la toma del San Cayetano en el 2006. La toma desde El Encuentro Territorial contaba con la participación de la parroquia Santa Teresa (Tania y los curas Enrique, Camilo y Mariano) referentes de otros asentamientos de Varela (Mary incluida) y Ariel. Tenían mapas con los lotes, las calles, los espacios públicos y delegados por manzana. La habían proyectado para el 23 de agosto. Me pidieron que no concurra ese día para evitar quedar expuesto ante las autoridades de la Municipalidad.

\section{Conclusión}

El crecimiento del Encuentro Territorial en organización e integrantes, su mayor visibilidad pública, con la motorización y la experiencia del Centro Mugica en otros asentamientos, resultó ser la base para que este espacio planificara una nueva toma ante el estancamiento de las negociaciones con el municipio. Mi lugar en la nueva toma, la habilitación de Robles que selló con la frase "preparate Luciano" y el vínculo con el Encuentro Territorial, fue el resultado en

\footnotetext{
${ }^{75}$ A principios de octubre se daría ese encuentro en La Plata, con la presencia de varias organizaciones y de Cristina Cravino, quien tuvo una excelente predisposición al igual que las autoridades (Claudio Ríos, José Scelsio) de la facultad que me brindaron el aula magna, viáticos y no cuestionaron que haya sido una convocatoria cerrada. Unos meses después, Robles convocaría a Cravino para un encuentro en Varela con un arco importante de organizaciones.
} 
el que desembocó la coordinación con Mary, Tania, los curas y mi intervención y la de las residentes en el 7 de abril. La propuesta de Robles de que por mi intermedio conseguir datos del PROMEBA y la organización de la charla en la facultad con Cravino fue otra manera que tuvo él y el Encuentro Territorial de fortalecer mi compromiso con ellos y agenciar mi saber profesional.

Como alguna vez se lo había escuchado a Ariel y Emilio cuando se decían entre sí "no nos pelemos con nadie, todos nos sirven", Robles, Mary y Tania también buscaron sumar sus aliados para el plan de acción que habían diseñado. Entre esos aliados estaba yo, el trabajador social de la salita que había mostrado cierto compromiso con atender a las familias del asentamiento y buena disposición para conseguir los datos con los que Robles legitimaría públicamente la denuncia sobre las deficiencias de la política municipal y el reclamo por tierras. Si en aquella fragmentación y soledad del invierno mi entusiasmo me había llevado a complicar mi lugar en el asentamiento, hasta casi no poder sostener el vínculo con las familias que permanecían "el campamento indio" poniendo en crisis mi rol profesional y mi posibilidad de acceder al campo, ahora volvía a recibir una nueva habilitación para entrar en la toma. Mi expectativa como profesional, pero también como investigador que pretendía hacer una etnografía parecía que finalmente sería satisfecha. Pero para volver a entrar, también me tocaba poner mi parte en una red de reciprocidad que Tania y Mary habían ido tejiendo con cautela y empeño para llevarme hasta el encuentro con Robles. No tan curiosamente, dejándome llevar por los actores, como suelen solicitar al etnógrafo los manuales de metodología, finalmente me constituiría como un trabajador social en la toma. 


\section{CAPÍTULO 6}

\section{ACOMPAÑAR, SELECCIONAR, ORGANIZAR, MUDAR, TOMAR, HACER BARRIO.}

\section{Introducción}

En este capítulo analizaré el desplazamiento paulatino a nivel organizacional y dirigencial que derivó en un traslado geográfico de la toma y la definitiva conformación del asentamiento junto a la expulsión de la dirigencia vinculada al municipio. Este resultado se dará por el accionar conjunto del Encuentro Territorial. En la nueva toma confluirá la experiencia de los delegados de otros asentamientos, los clareteanos en continuidad con la tradición de sectores del obispado de Quilmes y las CEBs en tomas de tierras y la forma de llevarla adelante tomará la modalidad descripta por la literatura (Cravino,1997) (Merklen, 2001). En este proceso surgirán dos asentamientos, el 7 de abril y La Cañada, lo que demuestra el trabajo de acompañamiento desde el Encuentro Territorial. Sobre ambos asentamientos realizaré una comparación de sus procesos y la organización.

\section{1."Si el Estado no garantiza donde podés vivir, qué querés que hagamos." Los asentamientos 7 de abril y La cañada.}

Desde la charla que tuvieron Ariel y Emilio en una de las carpas del asentamiento de Villa Argentina, donde comenzaron a idear la toma del 7 de abril, habían pasado varios meses, con días de lluvia, tormentas, frío, miedo e incertidumbre. Además habían participado de numerosas reuniones, en la toma, en el municipio, en el Encuentro Territorial o el club Cristal. Sin embargo, la resolución de la toma del 7 de abril, al igual que la de Villa Argentina, no se concretaba.

En varios aspectos coincidan ambos asentamientos:

- Habían comenzado hacía varios meses desde los primeros días de abril.

- La policía custodiaba a los ocupantes, con la diferencia que en la de Villa Argentina, los agentes chequeaban que no ingresara ninguna persona nueva a la toma ni que llevaran materiales de construcción. Además hubo ocho días en abril que la policía no dejó entrar ni salir a nadie de la toma.

- Las dos tomas no habían seguido el modelo clásico de toma de tierra, es decir, antes de la ocupación no tenían planos de los terrenos con los lotes, ni estaban organizados en comisiones, ni tenían delegados formales. 
- En ambas hubo un grupo relativamente estable de personas que vivían en los terrenos y otras que no estaban, pero debían garantizar su presencia cuando pasaban lista como criterio para su permanencia.

- Habían acudido al abogado Robles y a la parroquia Santa Teresa. La diferencia era que en el 7 de abril la presencia de Emilio fundamentalmente y su articulación con funcionarios del municipio había disputado la referencia del Encuentro Territorial.

- El municipio había ofrecido a ambas tomas soluciones insuficientes, como el traslado a unos pocos lotes en la zona rural.

- En las dos tomas se eligieron finalmente delegados que participaron del Encuentro Territorial para Todos y Todas.

Otro aspecto fundamental era que desde el Encuentro Territorial habían concluido que en los terrenos donde estaban ambos asentamientos no era posible permanecer y era necesario una nueva toma. Uno de los motivos de esta conclusión era, en el caso del 7 de abril, que esos terrenos tenían una cesión provisoria del municipio al Club Cristal por lo cual su presidente Mauro Mendoza, referente del PJ en el barrio, había comenzado a reunir a los padres de los chicos que concurrían al club para decirles que tenían proyectos y no se podían desarrollar en esos terrenos por la toma. Esto había ido generando una tensión en el barrio y habría sido uno de los puntos que trabaron las negociaciones. La disputa sobre la pertenencia o no de estos terrenos al club había estado presente desde el inicio de la toma con la discusión de Emilio y Mendoza. Emilio me diría más tarde en una entrevista que había acordado con Mendoza a quién "conocía de siempre en el barrio" en "no tomarles esos terrenos del club".

En tanto, para Robles, los meses de la toma, tanto en el 7 de abril como en Villa Argentina, habían servido para consolidar el "campamento" y que además y fundamentalmente, las negociaciones con el municipio tenían un propósito:

“aunque no te lleven a ningún lado, aunque vos tengas claro que te están haciendo la plancha para romper, desarmar la organización, también es un juego de legitimidad para nosotros, porque no es lo mismo armar un campo sin haber discutido con el Estado, que en un momento iban a decir tomaron un campo y nunca hablaron, a que siete meses, 26 actas, ustedes nos boludearon ${ }^{76 "}$.

Aquí Robles refería dos aspectos para garantizar y negociar con la futura toma, por un lado, el campamento consolidado y, por otro lado, el tiempo de permanencia en los terrenos junto a

\footnotetext{
${ }^{76}$ Entrevista a Pedro Robles realizada por el autor. Año 2017.
} 
haberse sentado a negociar con el municipio. Asimismo, desde el Encuentro Territorial, evaluaban que esto tenía un tiempo, dado que las personas se encontraban en condiciones infrahumanas y estaba el riesgo de que se produjeran muertes o que finalmente fueran desalojados. Para Robles esto era una responsabilidad de la organización: saber manejar los tiempos y los límites. Y a la vez ese mismo tiempo daba legitimidad para hacer una nueva toma. La organización y consolidación de la toma, el tiempo de negociación con el municipio y el tiempo de permanencia en la toma, atravesado por los límites del desgaste de las personas que tomaban, fueron los factores que impulsaron a la nueva toma. Pero, ¿cómo hizo el Encuentro Territorial para realizar una ocupación en terrenos tomables? Responderé esta pregunta en la siguiente reconstrucción.

El día designado para la nueva toma había sido el 23 de agosto, tal cual me lo habían adelantado en la casa de Mary. El desgaste del que luego me hablaría Robles se podía ver en cada persona del "campamento indio". Unas vecinas, que serían entrevistadas luego por Amelia y Pablo, lo recordaban así:

“...para venir a los lotes estos estuvimos haciendo reuniones cada 15 días, hacíamos actas, discutíamos esto lo otro, nunca hablaban del campo, si tenían un lugar, siempre tenían un pelo, si éramos de Varela o no, nos hicieron juntar boletas de luz de 5 años atrás, hasta el ADN nos pidieron" 77

En el asentamiento de Villa Argentina la situación era similar: "al principio éramos 160 familias y después terminamos 80. Hubo gente que se acobardaba por los chicos, porque no podían. Era pleno invierno y los chicos se enfermaban, entonces se iban ${ }^{78, "}$

Ariel, ya consolidado como delegado e integrante del Encuentro Territorial, agregaría que un mes y medio antes de la nueva toma, desde este espacio ya no concurrían a las reuniones con el municipio y se dedicaban a "mirar lugares donde meternos" y que por "conexiones en provincia" se habían enterado de esos terrenos. En tanto, Robles me diría:

“...entonces cuando se decide ir allá, en términos de una tierra que era alta, que no se inundaba, una tierra que no estaba contaminada para nada y una tierra que estaba en manos de una banda, de un subcomisario que tiene una empresa de colectivos que en ese lugar en el 2008, había habido detenidos por allanamiento por drogas y fueron detenidos los caseros de este tipo, entonces lo que ahi hicimos

\footnotetext{
${ }^{77}$ Segmentos de entrevistas recogidas del video "7 de abril", realizado por Amelia García y Pablo Sanhueza disponible en https://www.youtube.com/watch?v=68xg1WOOJw0

${ }^{78}$ Entrevista a Elena y a Edith, realizada por las residentes Jalo, Fischer y Smieunh en el marco del ASIS (análisis de situación de salud) en el asentamiento "La cañada". Año 2013.
} 
fue jugar ese estudio, bueno, él es un tipo de contacto, cuando él mueve sus contactos políticos lo que hacemos nosotros es hacer llegar una copia del allanamiento del 2008, "si quieren defender a un narcotraficante, háganlo no hay problema, vamos a decir públicamente que ustedes lo defienden”. Luego agregaría “...yo creo que uno lo que primero piensa es que el Estado garantice soluciones habitacionales con luz con agua, uno cree en eso (...) si el Estado no garantiza donde vivir, ¿qué querés que hagamos?: la toma no es la primera opción, es la segunda opción frente a la inacción estatal (...) en esos seis meses no hubo solución real y ahí apareció la opción de la toma ${ }^{79 "}$.

El diario local Varela al día en la entrevista que le realizarían a Robles (en la toma al día siguiente) éste haría estas mismas afirmaciones, agregando que se había presentado el comisario retirado de la policía federal con cinco personas (policía de civil, aclararía) para amenazarlos diciendo ser los dueños de los terrenos ${ }^{80}$.

Robles no me brindaría directamente de donde obtuvieron el dato de esos terrenos, sino que lo pondría como parte del estudio que realizaban como organización, aunque también vale la pena aclarar que en la entrevista que le realicé me refirió que diferentes funcionarios municipales, a quienes conocía incluso desde la infancia, solían tener gestos con él, brindándole información e incluso advirtiéndole de ciertas maniobras que se gestaban allí para amedrentarlo. También me explicaría por qué pudieron en la primera toma pasar de la vereda a los terrenos y en la segunda toma ingresar a los terrenos pese a estar vigilados y que la policía "no llegara a tiempo" para impedirlo. Según Robles, la concepción religiosa del comisario (evangelista) a cargo del operativo había influido en la tardanza.

\section{2. "Yo hago tipo Luciano"}

Ante el agotamiento de las instancias de diálogo con el municipio y las propuestas, el Encuentro Territorial organizó la nueva toma, contemplando a los dos asentamientos ( 7 de abril y el de Villa Argentina). Para ello previamente eligieron quiénes entrarían en la nueva toma, según referiría Ariel "pudimos elegir gente que realmente necesitaba, yo hago tipo Luciano, asistente social, voy a la casa veo quién necesita. A los que no entraron al Humahuaca los mandamos para el otro lado (al de Villa Argentina)". Luego convocaron a delegados de otros asentamientos que junto a los curas, Tania y gente del Mugica, armaron una estrategia contando con el apoyo previo de otras organizaciones sociales y de derechos humanos.

\footnotetext{
${ }^{79}$ Ídem 103. El subrayado es mío.

${ }^{80} \mathrm{http} / / /$ varelaaldia.com.ar/viejo/archivos/articulo/3558/asentados-en-varela
} 
Esta estrategia implicaba ir a los terrenos, medirlos, hacer planos, subdivir los lotes, nombrar delegados cada veinte vecinos y ubicar a cada familia en un determinado lote. Tiempo después, Tania me pasaría los planos que utilizaron. El acuerdo con las familias asentadas era que un representante (preferentemente hombre según se desprende de las entrevistas) fuera parte del contingente que realizaría la toma mientras el resto se quedaba en la carpa de la primera toma, así no se levantaban sospechas. Ese 23 de agosto se reunieron a las dos de la madrugada en las inmediaciones de la parroquia Santa Teresa, conformándose dos grupos, uno con personas del 7 de abril y otro con personas del asentamiento de Villa Argentina. Los delegados de otros asentamientos e integrantes del Encuentro Territorial como Mariano, se repartieron en ambos grupos. Cada grupo subió a un camión con algunos elementos, carpas, ollas, linternas, herramientas para desmalezar. Ariel recordaría que los camiones marcharon por caminos diferentes hacia los terrenos; el camión donde iba él dio toda una vuelta para no pasar por la toma anterior, donde vigilaba la policía a las carpas, mayormente vacías. Al llegar a los terrenos, unas cuatro hectáreas, comenzaron a desmalezarlo en su totalidad sin marcar aún cada lote. Como señalé anteriormente la policía llegó tarde a la nueva toma, lo que Robles explicaría por las creencias religiosas del comisario y Ariel directamente lo vincularía a "era evangelista y conocido de Pedro, había acuerdo de que llegara más tarde". Luego de desmalezar fueron subdividiendo los lotes con estacas, respetando las dimensiones de 10 x $20 \mathrm{mts}$, las calles y espacios comunitarios. Cada lote ya estaba asignado con nombre y apellido por lo tanto no existía la posibilidad de cambiarlo. Elena señalaría cómo su marido quiso elegir otro lote y Alfonso, un delegado de otros asentamiento e integrante del Encuentro Territorial, le señaló que debía respetar el que le había tocado. Paulatinamente todas las personas fueron levantando las carpas y construcciones precarias a lo largo de la jornada y consolidando las viviendas en las siguientes semanas, lo cual era importante para el Encuentro Territorial y para esas personas “...el abogado ya nos exigía a hacer casillas, cerrar el terreno, que no parezca una villa, que ya sea un barrio. Cada uno tenía que cercar su lote. Porque si era una villa nadie nos iba a reconocer. Nosotros tampoco queríamos una villa, queríamos un barrio ${ }^{81}$ ".

De la toma de esas cuatro hectáreas surgieron dos nuevos asentamientos divididos por la casa del dueño de los micros escolares, por un lado el 7 de abril y del otro lado La Cañada, nombre que se decidió en una asamblea. En uno de los predios, ubicado en las calles La Paloma y Humahuaca se asentaron 44 familias. Y en el otro predio, localizado en las calles La Paloma y 568 se afincaron unas 104 familias.

\footnotetext{
${ }^{81}$ Ídem 78.
} 


\section{3. "Saldivar era un cachivache": el desplazamiento de Emilio y de Leonor}

"Saldivar era un cachivache, al final Enrique (el cura) lo echó a la mierda, creo que estaba con Mereles". Así me dijo Robles unos días después de la nueva toma, en tanto Leonor ya había sido apartada luego de conocerse los resultados del censo donde habría surgido que tenía una vivienda en el asentamiento 9 de mayo.

En los numerosos encuentros que tuve con Emilio Saldivar, previos a este desenlace, me había mencionado en dos ocasiones su afinidad con Mauro Mendoza, del club Cristal y con el funcionario Víctor Mereles, además de afirmar que a él lo respetaban otros funcionarios por esta cercanía. En la entrevista que tuvimos dos años después, me confirmaría estas relaciones. Con Mauro Mendoza, con el cual se conocía “desde chicos”, Emilio negociaría en la primera instancia no tomarle parte de los terrenos del Club, en segunda instancia lograr que el tráiler de salud (algo deseado por los ocupantes) se estacione delante del club y no de la parroquia. Para Emilio todo esto fue parte de una estrategia, de la mejor que él podía hacer.

"Por eso te digo, fue como acá, acá fue toda una estrategia, yo sabía a qué gente fui y hablé ¿para qué? Para que nos salga bien las cosas. Yo sabía que podía contar con vos en la toma como esa, podía contar con el hombre ese, Victor Mereles, podía contar con Mauro, que ahora hay gente de Mauro viviendo allá atrás ¿me entendés? Entonces yo no busqué el choque, busqué la estrategia al revés, cuando Robles quería ir al choque. Yo cuando hablé con Víctor me dijo "mira, Robles no va, si hacen la toma, hace la toma. Vení a hablar conmigo, después tenemos la reunión con Mariana y vemos a qué arreglo llegamos". Ariel dijo que no, que teníamos que tener un abogado y lo llamó a Robles, a lo cual comparto porque éramos los dos referentes y valía la decisión de los dos y bueno, fue cuando vino el patrullero $^{82, "}$

Víctor Mereles responderá nombrándolo como referente en el municipio ante otros funcionarios, en desmedro de Robles y de Ariel, del Encuentro Territorial en sí, más allá de que las reuniones que convocaba el secretario de gobierno incluían a todos. Emilio me detallará en la entrevista cómo Mereles lo convocaría a reuniones para desautorizar a Robles y por fuera de los acuerdos que iban teniendo en el municipio, lo que fue generando lógicamente la distancia

\footnotetext{
${ }^{82}$ Entrevista a Emilio Saldivar realizada por el autor. Año 2013.
} 
entre él y Ariel y Robles. Para Robles, este accionar de Mendoza y Mereles, era más complejo y esa primera mención de "cachivache" hacia Emilio, la cambiará por un análisis más profundo en la segunda entrevista que le hice:

“...yo creo que siempre hay un conflicto entre la tarea que hace el resto del PJy los vestigios que le quedan, que, si tienen vasos comunicantes con el barrio, no para organizarlo pero si para generar ruido, empiezan a jugar con "yo conozco, tengo fideos, tengo unos planes, bueno si vos querés, si ustedes bajan el quilombo la solución para ustedes está”. Lo de siempre, dividir los grupos, yo creo que se aprovechan, hay una práctica de abuso que tiene que ver con que vos te abusas de las condiciones en las que el otro vive y de su historia y ahi es jodido, yo creo que los tipos no tienen problema en eso, porque el que descomprime el conflicto tiene premio, si Mereles o Mauro Mendoza lograban destrabar el conflicto es como que podes contarle a tu jefe político, "viste yo lo arreglé" y si no lo arreglas, te dicen “es tu territorio”. Mendoza vivía a dos cuadras, “ ¿cómo es que no podes controlar eso?". Es una situación perversa, por un lado, el que lo manda a Mauro Mendoza, le dice, loco vos no controlas el territorio, sos un gil, entonces Mauro tiene que tratar de convencerlo y de hacer todas las tareas sucias para destrabarlo. Esa vieja práctica de control del territorio que es la de los punteros, el más respetable era el que más territorio controlaba, cuando uno piensa en Mussi en Berazategui y acá si les estalla un conflicto y pasan los meses y no lo controlan, sos un gil. Hicieron todo lo posible para romper todo"

Queda claro que para Robles, Emilio fue ¿victima/partícipe? de la estrategia de los funcionarios municipales para romper la toma generando "ruido". En esta misma línea puedo pensar los aportes de Merklen (2005) cuando afirma que los partidos políticos que controlan el Estado no están en condiciones de ofrecer soportes institucionales estables. Acuerdo en este sentido con el autor: en el proceso de la toma de tierra los operadores políticos del partido gobernante, como dice Robles, tratan y consiguen dividir a los dirigentes del asentamiento y no brindar ningún tipo de asistencia a las familias que están realizando la toma, desgastándola. Se podría afirmar que la discusión entre Frederic (2009) con su concepto de estatalización barrial y el de inscripción territorial propuesto por Merklen (2005) se complementan: los operadores del PJ no controlan el territorio, no tienen a su "gente" ahí, por lo cual boicotean la toma dividiendo a sus dirigentes y negando el reconocimiento estatal que garantizaría recursos y legitimidad para que el nuevo barrio pueda sostenerse. 
Asimismo, es interesante pensar el planteo de Merklen (2005) cuando afirma que el barrio se presenta como un lugar privilegiado para la organización de solidaridades y cooperaciones, base de la acción colectiva y fuente de identificación. Por lo expuesto, considero que en este caso no es posible pensarlo así, el barrio es un espacio de disputa entre distintos actores sociales que no necesariamente son una expresión barrial y es un escenario de desconfianza. No es un bastión de resistencia, es una posibilidad de resistir, una más, y no es homogéneo. Emilio lo expresa en su temor a "los avivados que quieren terrenos" en las personas que por miedo se van ante la presencia policial, "los pibes que se drogan y hacen quilombo" y por los "políticos" o los que están con ellos y venden recursos de ayuda social. Las personas del barrio pueden realizar acciones colectivas pero eso no impide las salidas individuales y muchas veces la pelea por lo colectivo se convierte en un recurso que se canaliza para garantizar esa salida personal. Y esto lo afirmo sin caer en consideraciones morales.

En el caso de Emilio, esa salida personal fue su último recurso para "tener un lugar donde vivir" y de qué trabajar. Cercado por los acuerdos políticos con los funcionarios municipales cuyas promesas no se concretaban su lugar en la toma fue deslegitimándose y al ser señalado por el Encuentro Territorial como "cachivache", se fue quedando sin opciones. Antes de ser expulsado de la toma por el cura Enrique, intentó organizar una nueva ocupación, al igual que el Encuentro Territorial pero sin el dato sobre que terrenos podían ser tomables. La marginación de Leonor luego del censo implicaba que ya no disponía de referentes reconocidos por la gente del barrio para aliarse. En soledad y con la urgencia de su situación familiar se concentró en resolver la situación de la vivienda donde estaba arreglando con la dueña del terreno, donde vivía de prestado, para quedarse allí. Por otro lado ese terreno antes era una huerta comunitaria del MTR que no pudo continuar. Unos días después Emilio pasaría a contarme que había logrado comprar la casilla y que había dejado la toma porque ya tenía casa. En la entrevista que realizamos dos años después Emilio tuvo un planteo más heroico de su ida de la toma y me confirmó que a partir de las gestiones de Víctor había podido ingresar a las cooperativas (al igual que su madre a pesar de que vivía en Lanús). El planteo de Robles sobre el aprovechamiento que hicieron los funcionarios del PJ de Emilio tiene asidero pero no alcanza a explicar por qué actuó de esta manera. En esos meses Emilio hizo uso de lo que había aprendido en su trayectoria como piquetero, esto es: utilizar medidas de fuerza, organizar asambleas, negociar con funcionarios del municipio a quienes conocía justamente por ser piquetero y del barrio, pensar estrategias, disputar con otras organizaciones, todo esto en un contexto donde su familia y él vivían en las difíciles condiciones de vida que describí. Su capacidad de organización, resistencia y negociación permitió que la toma se sostuviera y su alianza con los funcionarios municipales y 
referentes del PJ se fue construyendo paulatinamente ante la desconfianza sobre Robles que alguna vez le había dicho "los piqueteros nunca ganaron nada" y que había ordenado quedarse en la vereda implicando perder gran parte de los terrenos ante el horticultor y el club. La frase de Robles significó un insulto a la identidad de Emilio que a pesar de haber estado preso por ser piquetero en el 2002 no temía presentarse así ante nadie ni siquiera frente al Comisario los primeros días de la toma, cuando estaban cercados por la infantería. Su apuesta por la alianza con los funcionarios fue fortaleciéndose ante ciertos logros (el trailer de salud, mercadería, reuniones en la municipalidad) y la afinidad que sentía por Mauro Mendoza.

Su expulsión de la toma se dio por el desgaste que le implicó esta estrategia y fundamentalmente por la fuerza del Encuentro Territorial que supo conseguir una salida por fuera del municipio para el resto de las personas de la toma.

Un aspecto que quiero destacar es mi relación con él. Como afirmé antes en el marco de mi trabajo en la salita encontré el expediente sobre la toma del 9 de mayo, mis ansias de investigar el tema desde la maestría, me llevó a conocer a Emilio y él me llevó a la nueva toma. Nuestra relación siempre estuvo mediada por mi trabajo en la salita y mis intereses académicos, las solicitudes de Emilio de pedir ayuda social para su familia y luego pedir mi compromiso con la nueva toma. Tuvimos ciertos acuerdos tácitos: podíamos criticar a otros actores sociales, que a pesar de las simpatías o acuerdos que tuviéramos cada uno, no diríamos nada sobre ello. Por ejemplo, Emilio no podía obviar que yo tenía acuerdos con el Encuentro Territorial y que mis intervenciones en la salita siempre estaban dirigidas a señalar y denunciar los manejos de la municipalidad y del P.J. A su vez yo sabía su afinidad con Mereles y con Mendoza y sus resistencias hacia Robles y Ariel. Jamás ninguno de los dos rompió ese acuerdo tácito de no decir nada; a mí me hubiera traído problemas con mis jefes y a él se le hubiese complicado aún más su situación en la toma. Otro acuerdo fue que él podía seguir viniendo a la salita a solicitar recursos y yo seguiría realizando los informes que él me pidiera. Nuestro lugar en la toma nunca modificó eso.

\section{Conclusión}

El Encuentro Territorial se constituyó en la referencia dirigencial y organizativa de las personas asentadas desplazando a Emilio cuya estrategia de negociación con los funcionarios municipales le costó su lugar en la toma. Emilio desplegó todas las herramientas que había aprendido en su recorrido de militancia social en pos de garantizar la viabilidad de la toma 
desde la organización inicial, coordinando con Ariel, hasta enfrentarse con el Comisario y negociar con Mendoza, cuya afinidad con él por la pertenencia barrial se oponía con la de Robles, alguien del “centro". En sus años de militancia piquetera había aprendido que para lograr algo debía combinar la fuerza y la negociación y que el costo del proceso lo pagaba en su cuerpo y con la postergación de su familia. En eso se diferenciaba de Robles cuya militancia de innegable compromiso social no tenía el costo de estar jugándose la posibilidad de la sobrevivencia familiar. $\mathrm{Y}$ también se diferenciaba de Ariel donde la toma fue su primera experiencia de lucha social.

La apuesta de Emilio por coordinar con los funcionarios municipales tuvo que ver con esto y no fue casual la presencia de Mereles que el mismo Walter de la ATV lo nombraba como alguien que acercaba posiciones entre el municipio y su movimiento. Mereles, con experiencia en negociar con organizaciones sociales, fue el encargado de profundizar la alianza con Emilio con la facilidad de que se conocían desde la toma del 9 de mayo y de los tiempos de militancia de Emilio en el MTR y la ATV. Esto si bien trajo algunos logros que Emilio canalizó en su disputa con el Encuentro Territorial, fue lo que finalmente lo expulsó de la toma ya que ni Mereles ni Mendoza, ni los funcionarios municipales, estaban interesados en resolver la toma a partir de otorgar esos terrenos u otros. Emilio, agotada esta coordinación quiso organizar una nueva toma, pero ya era tarde.

En nuestra relación, Emilio me había llevado a la toma para garantizar el apoyo de la salita y cada vez que me contaba las negociaciones con el municipio y las diferencias con Ariel y Robles intentaba consolidarlo, aun sabiendo que mi compromiso con el Encuentro Territorial iba creciendo día a día. Sin embargo supo respetar esta elección y supo cuidarme evitando exponerme con el municipio y los referentes del PJ en el barrio.

El Encuentro Territorial tuvo en este año un crecimiento significativo y supieron canalizar el aprendizaje de años de acompañamiento a otras tomas por parte del Centro Mugica y el empuje de los curas y Tania, en el contexto de la tradición del obispado de Quilmes. Fue la primera vez que organizaron una toma en conjunto. Las dos nuevas tomas que resultaron de este proceso, contemplaron la organización previa, el conocimiento de los terrenos, los delegados por manzana, el apoyo y participación de organizaciones e incluso el acuerdo con el comisario de la zona. También seleccionaron que personas estarían basándose en la necesidad; como decía Ariel sobre mi trabajo "tipo Luciano" refiriéndose a la evaluación/selección para la asignación de lotes en las tomas. Hay coincidencia con la literatura en estos aspectos y en el accionar de los clareteanos en continuidad con la tradición de sectores del obispado de Quilmes y las CEBs 
de apoyar tomas (Merklen, Cravino, Manzano, Woods), aunque el acuerdo con el comisario fue algo novedoso.

La legitimidad y posibilidad de hacer las tomas para el Encuentro Territorial, se midió por las negociaciones truncadas con el municipio, los meses de espera y el desgaste de las personas que ocupaban los primeros terrenos. La toma de nuevos terrenos que ocuparon fue una audaz decisión política que barajó el Encuentro Territorial, tomando terrenos de una banda mixta (policías y delincuentes comunes) vinculada a la venta de drogas, lo que también constituye un aspecto novedoso. Esto último no lo puedo enmarcar como un enfrentamiento entre organizaciones sociales y bandas de narcotraficantes como lo afirma el Cels (2016) Tufró, Brescia y Lefevre (2016) cuyas investigaciones si bien contemplan la experiencia del 7 de abril, destacan otras tomas posteriores donde se dio el enfrentamiento. La idea de tomar esos terrenos tuvo el objetivo de que el municipio no pudiera cuestionar de ningún modo la legitimad de la toma, lo cual resultó así pero tendría otros costos de enormes proporciones para el Encuentro Territorial. 


\section{CAPÍTULO 7 \\ ENTRE EL DESGASTE DEL MUNICIPIO Y EL APRIETE DEL OBISPO. LA CONSOLIDACIÓN DE LOS NUEVOS BARRIOS Y EL FIN DEL ENCUENTRO TERRITORIAL.}

\section{Introducción}

En este capítulo desarrollaré cómo desde el Encuentro Territorial se me convoca en conjunto con las residentes, para pensar estrategias con el objetivo de obtener ayuda social por parte del municipio para los nuevos asentamientos. Este agenciamiento del saber profesional por parte de la organización demuestra el carácter relacional del Trabajo Social, donde la intervención debe leerse no sólo por las decisiones de los profesionales sino por lo que las redes territoriales hacen y esperan de ello. Frente a las maniobras dilatorias del municipio para otorgar recursos iremos debatiendo con el Encuentro Territorial qué estrategia utilizar y qué tipo de intervención realizar desde la disciplina.

En tanto, las maniobras del municipio generarán cansancio y desgaste en los integrantes del Encuentro Territorial. Sumado a esto los clareteanos sufrirán el apriete de parte de la cúpula eclesiástica del Obispado de Quilmes por su acompañamiento a la toma de tierra. Este apriete implicará un reordenamiento de ellos en el interior del Encuentro Territorial, con un repliegue de su presencia en las negociaciones con el municipio, lo que sumado a otros conflictos que se darán en los años siguientes producirán el final de la alianza entre ambas organizaciones. De la articulación nacida en el 2006 y consolidada con la primera toma realizada en conjunto en el 2011 surgirán los dos barrios que sobrevivirán a la ruptura.

La conformación del 7 de abril y La cañada marcaran para mí el final del proceso de investigación constituyendo mi salida del campo y finalizando mi intervención allí como trabajador social en el marco de un proceso de toma de tierras.

\section{El cansancio de Tania y las estrategias para obtener ayuda social.}

Una vez realizada la toma el 23 de agosto, junto a las residentes decidimos aumentar nuestra presencia en el nuevo asentamiento en coordinación con las organizaciones del Encuentro Territorial. Nuestro objetivo era aportar desde el Centro de salud y la residencia al proceso del nuevo asentamiento para lograr su consolidación y reconocimiento estatal. Considerábamos que podíamos trabajar cuestiones sanitarias, generar accesibilidad a la salita, distribuir recursos preventivos (salud sexual, materno infantil, etc.) y realizar diagnósticos sanitarios que pudieran ser utilizados por las organizaciones en los reclamos y negociaciones con el municipio. 
Asimismo podíamos trabajar situaciones problemáticas de violencia familiar, abuso sexual infantil y realizar encuestas sociales para pedir recursos destinados a las viviendas.

Con estos objetivos nos reunimos con Robles, Mary y Tania en la Asociación Civil Mirada al Cielo en el barrio 9 de mayo. Cuando estábamos llegando, Tania, sabiendo que la escuchaba, le dijo a Mary "ahí viene el etnógrafo", seguido de una carcajada tan cálida como habitualmente era en ella. Esto no era más que el reflejo de nuestras conversaciones sobre lo que veía en la maestría y el material que compartíamos.

En el transcurso de esa reunión nos contaron algunas novedades del nuevo asentamiento entre ellas el hecho que habían dejado un lugar para armar un centro comunitario. Luego nos invitaron a un taller de delegados del Encuentro Territorial que se desarrollaría en la sede del Centro Mugica para hablar con los delegados de varios asentamientos sobre nuestro trabajo en salud. Después comenzamos a definir los ejes de la charla que daría la antropóloga urbana Cristina Cravino en la Facultad de Trabajo Social. Para Robles era importante plantear la coyuntura de Varela y previamente a la charla pasarle a Cravino un proyecto del Concejo Deliberante sobre suelos urbanos para que sea parte del debate; él consideraba que había que ampliar la discusión de las tomas de tierra e instalarlo como un problema que tenía que ser ingresado en la agenda pública. Otro tema que abordamos fue el del PROMEBA dado que ya habíamos conseguido el resultado del relevamiento. Acordamos que debíamos sistematizar la información y socializarla en diferentes ámbitos por ello nos comprometimos a socializarlo con las instituciones de la Red Contra la Violencia.

Desde mi trabajo asistencial en la salita les pude contar que el Secretario de Salud y Desarrollo Social estaba articulando con Defensa Civil para entregar recursos apesar que no estábamos en ninguna emergencia climática que ameritara eso. Mi análisis era que utilizaban los recursos de Defensa Civil compuestos por una cuadrilla de empleados y móviles con capacidad operativa para trasladar chapas, colchones, en coordinación con los punteros de cada barrio. Esto, les dije, fortalecía la entrega discrecional de recursos por parte del municipio y fortalecía a los punteros en el barrio en desmedro del trabajo de los trabajadores sociales quienes diariamente reclamábamos que se les diera curso a nuestros pedidos mediante informes y encuestas sociales. Para finalizar la reunión acordamos encontrarnos unos días después en el nuevo asentamiento con la idea de articular con los nuevos delegados e incorporar al EFAPS ${ }^{83}$ para diseñar una estrategia de trabajo sobre la salud de la población del nuevo barrio.

\footnotetext{
${ }^{83}$ El Equipo de Fortalecimiento de Atención Primaria de Salud (EFAPS) era un grupo de profesionales de diferentes disciplinas y pertenecientes a diferentes sectores creado por la Secretaría de Salud de Florencio Varela
} 
Esa reunión se realizó el miércoles 14 de septiembre de 2011. Allí me encontré por primera vez con la totalidad de la red de trabajo que habíamos construido en todos esos años de Varela. Fue significativo que ese encuentro se diera en el nuevo asentamiento ya que todos desde diferentes lugares habíamos bregado para eso. Estaba Tania representando al Encuentro Territorial, Mary Herrera e Isabel ambas delegadas del Encuentro Territorial y promotoras de salud de las salitas La Esmeralda y Santa Teresa, Ariel y Liliana delegados del 7 de abril, las residentes de trabajo social (Amelia, Lorena y Pablo) y Sergio y Stella por el EFAPS.

En el inicio de la reunión Tania nos informó que en el asentamiento 7 de abril eran 44 familias distribuidas en dos manzanas. La mayoría provenía del barrio La Esmeralda y a muchas de ellas desde que estaban en la toma les habían dado de baja del plan Vida. Por otra parte en una reunión con mi jefa Graciela Ocampo, frente al pedido de recursos, ésta les había dicho "que los sociales hagan encuesta social y habrá respuesta". A esto respondí que éstas podían ser utilizadas para dividir los reclamos de recursos de una misma población. Tania respondió que pensarían cómo encarar el reclamo y que también desde la Secretaría les habían ofrecido llevar el tráiler de salud pero dudaban de aceptarlo porque atendían sin historia clínica. Sergio y Stella propusieron realizar una reunión en la salita de La Esmeralda para ver cómo garantizar la atención de la salud y por otro lado, ofrecieron una planilla de relevamiento. Dicha planilla ya había sido utilizada en la salita del barrio Luján durante la toma del asentamiento San Cayetano cuyos datos sistematizados fueron un importante insumo para las negociaciones con el municipio. Lorena y Amelia opinaron que esa planilla también podía ser incorporada para los futuros ASIS (Análisis de la Situación de Salud) que realizarían en la residencia.

Los días siguientes a esta reunión transcurrieron con entusiasmo para mí y las residentes. La coordinación para la charla de Cravino no presentó dificultades y entre tanto mi trabajo asistencial no se detuvo, al igual que la organización de las reuniones de La Red Contra la Violencia familiar. Por primera vez sentía que había podido trascender el trabajo inmediatista (Iamamoto, 1992) que me frustraba tanto.

Nos volvimos a reunir con Robles, Mary y Tania en la Asociación Civil Mirada al Cielo. Al entrar a la copa de leche, Tania le dijo a Mary "Luciano me ayuda a pensar ideas porque yo estoy quemada", esta vez no lo dijo con su habitual carcajada, parecía agotada. Luego nos dijo que había hablado con los delegados sobre lo que charlamos en la reunión anterior en relación a como exigirle a Desarrollo Social chapas, frazadas, colchones y mercadería para cada familia. Ellos les respondieron que estaban preocupados por la necesidad imperiosa de obtener recursos

con el fin de generar acciones destinadas a mejorar la salud de la comunidad, desde una mirada que abarcara la totalidad. Tenían entre otras funciones, seleccionar a los promotores de salud para los centros de salud. 
sea con encuestas sociales o listados. Tania agregó que incluso desde el Encuentro Territorial evaluaban contactarse con personal de Desarrollo Social de Nación para hacer el pedido. Además nos contó que se habían reunido con mi jefa Graciela Ocampo y le habían recordado que incumplió todos los acuerdos, ella le respondió diciéndoles que se iba a comunicar conmigo para que vea los pedidos de los dos asentamientos mediante la realización de encuestas sociales. Les dije que lo importante en las encuestas sociales era ver cómo se completaba y qué se pedía, más allá de quien la hiciera, pero por sobre todo, lo más relevante era si Desarrollo Social tenía la decisión de entregar recursos y que no consideraba que mi jefa tuviera poder para resolver eso. Mi temor era el de siempre: quedar en el medio del conflicto y atado a la entrega o no de recursos. Y más allá de tener el apoyo del Encuentro Territorial, lo que había aprendido en esos años en Varela era que ante cualquier conflicto, el trabajador social era el que pagaba el costo. Incluso si quedaba visible que por mi gestión se habían conseguido recursos, eso podía implicar tener problemas con el resto de los referentes territoriales de los cuatro barrios y los dos asentamientos que componían mi área geográfica de trabajo. Este dilema tomó un cauce diferente al que yo esperaba. Mi jefa me llamó unos días después y me dijo “ $L u$, ya sé que vos trabajas con el barrio y no hace falta que yo te pida nada, pero las organizaciones me piden que te diga igual, necesitan recursos, yo te pediría que vos te ocupes". Le pregunté si tenía que hacer encuestas sociales y me respondió que no, que con un listado por familia alcanzaba. Ese llamado me desconcertó, en primer lugar me sorprendió el tono de su voz que no denotaba preocupación ni interés a pesar de que Tania y Robles, me habían contado que en las reuniones con ellos solían increparla duramente por su falta de respuestas. También me sorprendió que no pidiera encuestas sociales. Aparentemente esto marcaba que no lo iban a resolver por la vía clásica de Emergencia Social, llevando a preguntarme para que servían las encuestas sociales si había formas más rápidas de acceder a recursos. Entonces ¿para qué quería que yo hiciera el listado? Mi sospecha era que buscaban canalizar de alguna manera el reclamo para que pareciera que se estaban ocupando o simplemente dilatar el asunto y utilizarme de fusible. Llamé a Tania, y me dijo que era porque al otro día se reunirían con ella y hacía rato que le habían pedido recursos y no había hecho nada, que era para decir que hizo algo al respecto.

Al día siguiente nos reunimos al mediodía con Tania para hablar sobre el listado de recursos. Recién salía del municipio, parecía cansada, las negociaciones con el municipio resultaban agotadoras y las maniobras estatales seguían estando repletas de dilaciones y falta de cumplimiento de los acuerdos. Este desgaste era parte de la estrategia de los funcionarios municipales, el tiempo que iba transcurriendo sin respuestas podía llevar a que el Encuentro Territorial resignara parte de lo que exigían o que radicalizaran las medidas de lucha. Con seis 
meses pasados desde la primera toma, la desesperación, el hambre y el frio se sentían cada vez más en el asentamiento. Tania lo sabía y los funcionarios también. La entrega de recursos por parte de la Municipalidad tenía importancia por el nuevo contexto donde se daban las negociaciones, ya no era en el marco de la primera toma donde la municipalidad tenía referentes territoriales operando para desarmarla, ahora entregar recursos implicaba aceptar que la toma del Encuentro Territorial había sido exitosa y era una forma de reconocer la existencia de ese nuevo barrio.

Luego Tania me comentó que en la reunión donde había concurrido con Robles, los curas y delegados, estaban las funcionarias: Licenciada Ocampo, Noelia Pino (jefa del Área de Discapacidad) y un arquitecto llamado Sergio. Aquí Tania le planteó a Noelia Pino ${ }^{84}$ la situación de Paola ${ }^{85}$, criticándole a su área por la imposibilidad de concretar el acta acuerdo realizada unos meses atrás entre la parroquia, el Centro de Salud, el Ruca Hueney y ellos. Acordaron que yo le haría una encuesta por un subsidio de $\$ 1000$ para que armara la casilla en el nuevo asentamiento y que Pino hablaría con su equipo para informarse sobre cómo habían intervenido. Lo interesante de esta situación, que veníamos trabajando desde hacía años, era que se resolvió en el marco de la negociación del nuevo asentamiento, aquí y solo en este marco tuvieron valor nuestros informes profesionales donde pedíamos la intervención y asistencia de la Dirección de Discapacidad. Si Manzano (2008) afirma que en las tomas de tierras al pedido de tierra se incorpora la demanda por trabajo, en esta ocasión, puedo decir que se le agregó el reclamo por la resolución de situaciones sociales complejas.

Luego me contó que el municipio había mandado a Los Pilares, donde estaban los lotes sociales, algunos recursos en un camión, de manera desordenada, otorgándolos a personas al azar y generando muchos problemas. Tania estaba desconcertada, no sabía si acciones de este tipo era por ineficacia o malicia. En realidad, esta fue la respuesta al reclamo por recursos; si el Encuentro Territorial los solicitaba, estando dispuesto a que se otorgaran, sea por encuestas sociales, listados o como se dispusiera, el municipio respondía entregándolos de manera desordenada, sin criterios profesionales y al barrio Los Pilares, el mismo lugar que en las negociaciones previas a la segunda toma, habían ofrecido cinco lotes para todas las familias de los dos asentamientos. Si mi jefa Graciela Ocampo pese a ser duramente cuestionada en las reuniones por las organizaciones mantenía su tranquilidad, respondiendo con nuevas estrategias

\footnotetext{
${ }^{84}$ Noelia era una administrativa cuando empecé a trabajar en Varela, luego por sus vínculos políticos y personales le dieron la Dirección del Área de Discapacidad.

${ }^{85}$ En las notas del cuaderno de campo, del 28 de marzo, relato la primera reunión que tuvimos con el área de discapacidad por Paola (una joven paraguaya con discapacidad mental, con una hija de dos años y sin redes familiares).
} 
dilatorias, el cansancio y desconcierto en Tania se acentuaban. Por mi parte si algo había aprendido en Varela era a trabajar con el desconcierto que traían las respuestas de los funcionarios, la ayuda social no se resolvía sólo por los criterios y canales institucionales que el propio Estado proponía y exigía pero tampoco se podían desestimar porque se transformaban en la "excusa" para no otorgarla. Por ello acordamos con Tania y por su intermedio con el Encuentro Territorial (incluyendo a los delegados del asentamiento) que ellos mismos harían el listado de los recursos solicitados y yo firmaría. Unas semanas después, Ariel y "la peque" (otra delegada) me acercaron el listado con los datos de veintidós personas, cada una de ellas representaba a una familia y los pedidos se referían a colchones y frazadas, variando la cantidad solicitada de acuerdo al número de integrantes de cada familia. Al entregar el listado en Desarrollo me avisaron que el subsidio para Paola ya estaba listo. Al mismo tiempo, Tania, los curas y los integrantes del Ruca Hueney se habían puesto a organizar el espacio en los dos lotes que le tocarían en el 7 de abril a Paola y a su hermana con quien se acordó que debía cuidarla.

\section{El inicio del fin. El apriete del obispo y la ruptura del Encuentro Territorial.}

Tania en una de las reuniones nos dijo que la situación de ellos en la parroquia se había complicado porque el supuesto dueño de los terrenos del 7 de abril (un tal Mesa, el comisario retirado) fue a denunciarlos frente al obispo por hacer la toma. El obispo los había convocado y "para evitar juicios" les exigió un comunicado donde ellos afirmaran que no apoyaban las tomas. Tania junto a los curas Camilo y Enrique, habían realizado en lugar de un comunicado, un informe de todo el proceso del 7 de abril aclarando que "acompañaban a la gente". Para ampliarnos sobre la complejidad de la situación nos explicó la estructura eclesiástica del Obispado de Quilmes con los principales protagonistas y los posicionamientos que tenían al respecto: 


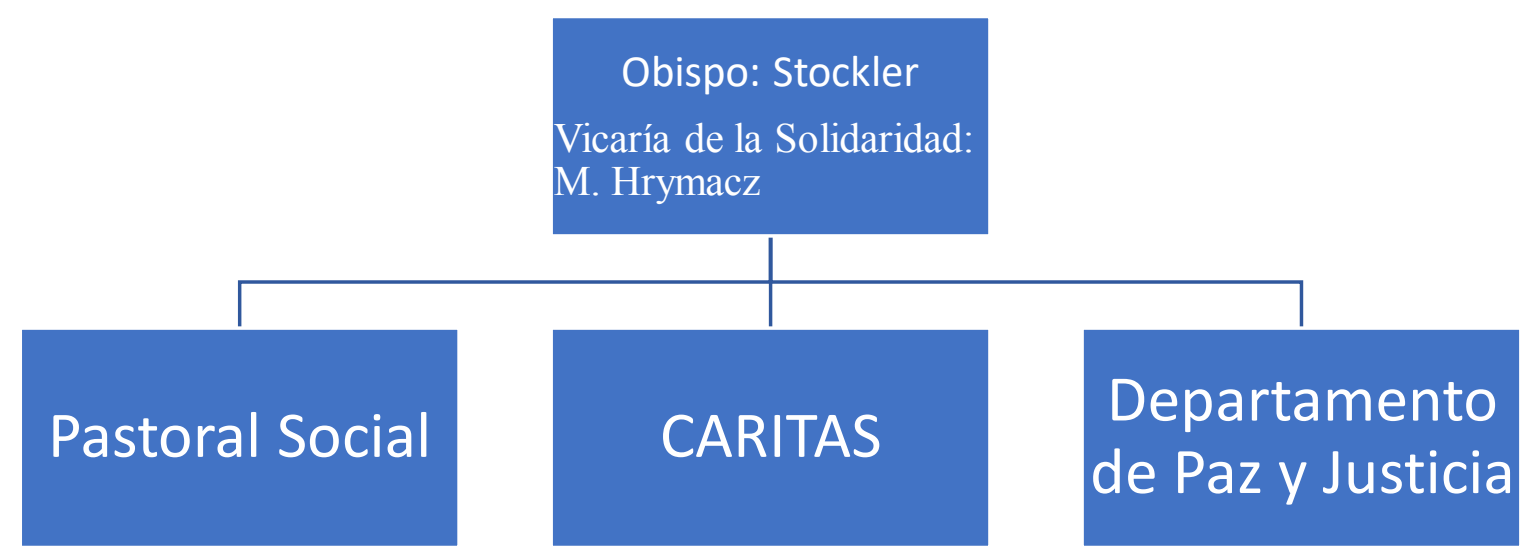

El cura Miguel Hrymacz tenía la postura más intransigente y directamente les había exigido a Enrique y Camilo que sacaran inmediatamente un comunicado diciendo que la iglesia no apoyaba las tomas de tierras. El cura Miguel, párroco de la Medalla Milagrosa, era el presidente de la Vicaría de la Solidaridad y de la Fundación Padre Miguel cuya vicepresidente era Graciela Gianetassio (ex vicegobernadora y diputada en ese momento). En tanto, la Pastoral Social respondía a él, por lo que apoyaban a la Municipalidad y a este pedido. Por otro lado, Caritas y el Departamento de Paz y Justicia solían acompañar a las tomas de tierra, pero no tenían el mismo poder que Hrymacz.

La preocupación de Tania, Camilo y Enrique era que si bien ellos dependían de la orden de los clareteanos el obispo les podía rescindir el contrato y sacarlos del obispado de Quilmes. A Enrique ya lo habían echado de Misiones; "no le renovaron el contrato" aclaró Tania con una sonrisa amarga. Para Robles, a diferencia de la postura de Tania, había que redoblar la apuesta y hacer una nueva charla con Cravino y otros invitados en la misma parroquia de Santa Teresa el 29 de octubre planteando esta situación. Esto fortalecería al Encuentro Territorial en general y obligaría al obispado a tomar partido públicamente. En esa reunión, ni Tania ni Robles refirieron que harían desde el Encuentro Territorial.

El documento que finalmente hicieron los clareteanos se titulaba "Informe de las familias asentadas en terrenos del barrio Santa Teresa en Florencio Varela” y había sido elevado al obispo. El mismo comenzaba con una cita que me llamó la atención, dado las luchas que sostenían desde la parroquia "Bienaventurados los pacientes, porque ellos recibirán la tierra por herencia" (Mt 5, 5), luego el documento se metía de lleno en la cuestión de la tierra y cuestionaban la desigualdad social en relación a la distribución de la tierra a partir de las palabras de San Basilio. A partir de esta cita, con referencias al censo del PROMEBA (2010) dando cuenta de los escalofriantes (sic) datos de la realidad, con los indicadores de NBI y 
reconociendo la presencia estatal en los planes de viviendas cercanos a las tomas, describían en general a las personas afectadas en las tomas y sus principales problemáticas ${ }^{86}$. Luego denunciaban la concentración de tierras en pocas manos y la abundante cantidad de terrenos ociosos como un escándalo frente a la gran cantidad de "hermanas y hermanos" en situación de emergencia habitacional, concluyendo que había una gran cantidad de familias necesitadas sin viviendas y demasiadas tierras sin usar.

Otro de los puntos importantes del documento era el de cronología de los pasos dados, donde detallaban las reuniones y acuerdos con el Municipio (nombrando a funcionarios, fechas, actas) desde los primeros días de marzo por el lapso de siete meses en la mesa de diálogo para resolver la situación de las familias para que pudieran acceder a lotes y construir sus viviendas con ayuda del municipio. El documento marcaba una fecha límite a esta situación, el 8 de julio, donde se detallaba las faltas de respuestas a mediano y corto plazo, puntualizando que éstas se daban en el contexto del invierno, con temporales, la muerte de un hombre y perdidas de embarazos. Por lo tanto, afirmaban, frente a esta situación las familias habían decidido tomar tierras disponibles en la zona y desde la parroquia habían acordado seguir acompañándolas en este proceso.

El último punto del documento se denominaba Situación actual de las familias asentadas y describía a las nuevas tomas (cantidad de familias, ubicación geográfica) luego del 23 de agosto. Aquí referían que se habían contactado con autoridades municipales para saber la situación dominial de los terrenos; las mismas ya les habían adelantado que Mesa no era el dueño. Asimismo, referían el trabajo de acompañamiento a las personas asentadas, el diálogo con el Estado municipal en pos de garantizar agua, alimento y la sanidad de las familias, el pedido de ayuda al SERPAJ (Servicio de Paz y Justicia) y el apoyo de diversas organizaciones sociales, legisladores, concejales y representantes de la diócesis de Quilmes: Caritas Diocesana, el Departamento de Justicia y Paz y la Comisión de Justicia y Paz de los Misioneros Claretianos. El documento terminaba enfatizando que seguirían estando cerca de estas familias y de sus vidas porque sabían que su lucha era legítima y justa.

Para Robles, en la entrevista que le realicé unos años después, este apriete del obispo generó el inicio de la ruptura del Encuentro Territorial dado que Tania, Camilo y Enrique luego del documento al obispo y de dialogar con él habrían acordado dejar de participar en las instancias de negociación con el municipio. En ese diálogo con el obispo, siempre en la versión de Robles,

\footnotetext{
${ }^{86}$ Familias jóvenes desalojadas. Familias jóvenes que viven hacinadas en las casas de sus familiares. Familias jóvenes con escasos recursos que no pueden mantener un alquiler. Mujeres víctimas de violencia, jefas de hogar con sus hijos sin vivienda, hacinadas en las casas de sus familiares o padres. Personas solas con problemáticas de salud: VIH, salud mental, adicciones, etc.
} 
se dejó traslucir que el proyecto de la "casa misión ${ }^{87 " ~ c o r r i ́ a ~ r i e s g o ~ d e ~ q u e ~ n o ~ s a l i e r a . ~ E s t e ~}$ apriete no implicó que Tania y los curas dejaran de trabajar fuertemente en ambos asentamientos, con una capacidad de planificación asombrosa para mí.

Mis dudas en torno al accionar del Encuentro Territorial ante este apriete son las siguientes:

- El Encuentro Territorial había previsto que si desde el municipio se cuestionaba la nueva toma, les responderían públicamente que al hacerlo estaban apoyando a un "narco” ¿Por qué no propusieron la misma estrategia ante el obispo y la vicaría de la solidaridad? ¿Era porque consideraban indispensable el apoyo del obispo, aun arriesgando la alianza entre ellos?

- ¿Por qué no hicieron público el Informe al Obispo? al no hacerlo perdió valor en la disputa con el obispado pese a los fundamentos contundentes que tenía.

- ¿Por qué el obispo apoyó la versión de un "narco" siendo que desde el municipio no lo hicieron? ¿O fue un acuerdo entre el obispo y el municipio?

El Encuentro Territorial no realizó ninguna estrategia que implicara exponer públicamente la gravedad de que el obispado apoyara a una persona sindicada como narcotraficante, tampoco compartieron con el amplio arco de instituciones y organizaciones el informe que realizaron. Así, la disputa de Tania y los curas quedó en mano de la misma jerarquía eclesiástica que los cuestionaba. En tanto, Robles me referiría que en la experiencia del Centro Mugica con el obispo ante los conflictos que tuvieron esos años, incluyendo una campaña de difamación realizada por el municipio contra Robles en el 2014, el obispo solía tener un doble manejo: por un lado solía llamarlo para brindarle su solidaridad de manera informal, pero por otro lado se reunía públicamente con el intendente. Al respecto hay algunas investigaciones que indagan sobre el Obispado de Quilmes y sus relaciones con organizaciones sociales en situaciones conflictivas.

Woods (2003) trabaja sobre los límites de la iglesia católica en sus intervenciones en los conflictos sociales territoriales referidos al trabajo y la tierra, en vinculación con organizaciones de desocupados. En su trabajo relata la experiencia del Movimiento de trabajadores desocupados de Francisco Solanos (Quilmes) y la expulsión del cura Spagnolo del obispado de Quilmes. Aquí, si bien hubo varios motivos y advertencias desde el obispado ante la reciente influencia del MTD Solano en el interior de la parroquia, la autora señala que debe analizarse

\footnotetext{
${ }^{87} \mathrm{La}$ casa misión era un proyecto que entusiasmaba mucho a Tania y a los curas, cuyo objetivo era "Crear una nueva posición apostólica en un contexto suburbano para que impulse el compromiso en la opción por los pobres y la justicia, la paz e integridad de la creación". La tenían planeada en el barrio La Esmeralda y se llamaría Daniel de la Sierra "por el trabajo de este cura con los pobres". Finalmente, el proyecto no salió, por causas que desconozco.
} 
no como “...un hecho aislado o anecdótico sino en función de límites estructurales dentro de los que se mueve políticamente (y establece alianzas) la Iglesia Argentina” (2003, p.18).

En este caso, aceptando ciertos límites en el análisis dado que trasciende este trabajo, puedo inferir que lo que generó el obispo en el marco de negociaciones y límites (como señala la autora) fue un reordenamiento de los clareteanos en relación a lo "que podían y no podían hacer" y "con quién sí y con quién no". Claramente en la correlación de fuerzas en el interior del Obispado la postura del obispo y la vicaría eran predominante ante otros sectores más progresistas cuya búsqueda, coincidiendo con Wooods (2003) de incluir el compromiso político con las organizaciones populares como forma del trabajo religioso fue severamente atacada. También puede agregarse al análisis que esta maniobra fue parte de un establecimiento de límites al crecimiento del Centro Mugica y a la figura de Robles, al cuestionarse desde el Obispado a los clareteanos pero sin tener un conflicto directo con este referente. El apriete marcó el inicio de la ruptura en el Encuentro Territorial y el fin de una manera de trabajar entre ambas organizaciones signada por la confianza y los acuerdos. Si bien este proceso fue paulatino, dado que al año siguiente Mariano participaría del proceso y de las mesas de diálogo por una gran toma en el barrio Lujan, el desacuerdo y la desconfianza se irían acentuando. Finalmente, unos años después con la creación de la Pastoral de Asentamientos, un espacio que según Robles era paralelo al Encuentro Territorial y desacuerdos por el uso del Centro comunitario del 7 de abril y unas becas de CARITAS para trabajar allí, la estrategia del obispado daría resultado. La alianza que tanto resultado había traído para las clases populares en Florencio Varela se disolvería ante la tristeza de Tania, los curas y el enojo de Robles.

\section{Conclusión}

Si mi ingreso al campo fue a partir de la red informal de trabajo que me agenció mi saber profesional en el proceso de la nueva toma, mi salida del campo se produce con la conformación de los dos nuevos barrios. En este momento de la toma mi intervención pasaba por tratar de pensar y realizar estrategias con el Encuentro Territorial para la obtención de recursos de ayuda social y entender el desconcierto que generaban las respuestas desde las agencias del Estado. En tanto, la planificación de actividades propias de la Atención Primaria de la Salud junto a las residentes y el EFAPS buscaban garantizar cierta accesibilidad a la salud para una población que considerábamos vulnerable y en riesgo y a su vez era una manera de fortalecer la legitimidad de esos nuevos barrios al menos dentro de la salita. Las charlas con Tania, Robles y Mary sobre qué hacer para obtener ayuda social y cuál debía ser mi intervención termina de confirmar algo que es reiterado a lo largo de la tesis: el lugar relacional del Trabajo Social en 
el territorio. Las posiciones cambiantes de mi lugar obedecían tanto a los lugares donde me iba insertando, a mis decisiones y también a la red que me fue involucrando en la toma. No fue una decisión individual profesional sino el resultado de decisiones influenciadas por el contexto como así también atravesadas por el agenciamiento y los modos en los cuales las redes sociales del territorio iban haciendo jugar/fluctuar mi lugar. Que firmara o no los listados de recursos, que hiciera encuestas sociales, que hablara o no con mi jefa, que concurriéramos con las residentes al nuevo asentamiento, que analizáramos la lógica de las políticas públicas, todo esto era resultado de lo que afirmé anteriormente. La afirmación de Tania "ahí viene el etnógrafo" o "me ayuda a pensar ideas porque estoy quemada", era un reconocimiento al lugar en el que ella y el Centro Mugica me convocaban a estar. Ese estar implicaba para mí brindar mi saber profesional al Encuentro Territorial en la puja política contra el municipio y para conocer cual debía ser mi aporte, debía estar en la toma. Esas maneras de estar se fueron retroalimentando en todo este proceso y no podría pensar una sin la otra. Hacer etnografía de una toma de tierras y de mi propia intervención profesional fue la posibilidad para lograr esto.

El estar en el campo me permitió conocer a los clareteanos y al Centro Mugica y entender cómo su lugar en la toma fue creciendo como espacio. En efecto, esta articulación resultó ser un nucleamiento capaz de disputarle al Municipio y a otros actores sociales la posibilidad de acompañar una toma de tierra con éxito y lograr que se consolide como barrio sorteando la dificultad de tener que dejar los terrenos ocupados en la primera ocasión y no sólo ello, sumar a otra toma y generar un proceso organizativo con delegados. Los dos nuevos barrios resultantes demuestran la capacidad del Encuentro Territorial en la disputa local, donde liderar tomas de tierras y organizar barrios o impedirlo es un capital político muy valioso en juego. Las negociaciones por los recursos deben leerse en este marco. Las maniobras dilatorias del municipio en otorgarlos tenían el doble objetivo de no reconocer la victoria del Encuentro Territorial en la puja política y aumentar el desgaste de esta organización y de las familias asentadas. Aun así, el Encuentro Territorial tuvo éxito en enfrentar las estrategias de los funcionarios y referentes municipales pero ante el apriete del obispo a los clareteanos y el reordenamiento que siguió carecieron de una estrategia en común. Si para Robles había que redoblar la lucha exponiendo públicamente el conflicto, para Tania y los curas la respuesta era dar explicaciones a partir del Informe al Obispo. Pero este informe, en manos de la misma jerarquía que los cuestionaba, no tuvo mayor impacto. El reordenamiento fue el primer paso hacia la disolución de la alianza, dado que para Robles los clareteanos iniciaron un repliegue público en las negociaciones con el municipio y apostaron por la estructura eclesiástica en lugar de fortalecer el Encuentro Territorial. En esta línea deben leerse los posteriores conflictos entre 
ambos integrantes, cuando no tuvieron acuerdos por el destino de unas becas de CARITAS y el uso del Centro Comunitario. La creación de la Pastoral de Asentamientos confirmaría el análisis de Robles. Tania y los curas siempre habían apostado a un crecimiento en la coordinación con las organizaciones populares y las instituciones estatales incluyendo nuevos integrantes de su congregación al trabajo barrial, desde estudiantes secundarios de colegios católicos hasta miembros de otras ramificaciones de los clareteanos. El apriete del obispo los colocó en una situación de la cual no tenían salida dado que enfrentar públicamente al Obispo podía implicar que los echaran del Obispado e incluso de la Iglesia Católica. Por eso el Informe al Obispo también puede analizarse como un intento, el único quizás, para resolver el conflicto en el interior de la estructura eclesiástica. Pero esto implicó resignar parte de lo que el Centro Mugica esperaba de ellos, como por ejemplo ser una de las caras visibles en la municipalidad, por lo cual se inició el final del espacio.

La articulación fue efectiva durante años y de esas primeras reuniones en el 2006 llegaron a planear la toma de tierras, quizás en el mejor momento como espacio. A pesar de la ruptura que se daría en los años siguientes, la consolidación de los dos nuevos barrios a los cuales seguirían acompañando pese a las diferencias, demuestra la capacidad de ambas organizaciones y el compromiso con las clases populares de Florencio Varela. 


\section{CONCLUSION FINAL}

La intervención del trabajador social en el territorio es el resultado de las decisiones profesionales pero también y fundamentalmente de lo que otros actores sociales hacen y buscan determinar sobre esa intervención. A lo largo de la tesis describí cómo este lugar relacional del trabajo social se fue construyendo en los entramados con los que me fui vinculando. Mis decisiones en torno a ello, el agenciamiento social de mis prácticas y saberes y los modos en los cuales las redes en el territorio iban haciendo jugar mi lugar como profesional resultó un aspecto medular de mi investigación. Esa trama me llevó a la toma. Por lo tanto, como afirmé en la introducción de la tesis, tomo distancia de las visiones normativas, morales e ideológicas de la profesión que pretenden dar definiciones estáticas sobre lo que somos. Sin negar que efectivamente existen esas características, pero la práctica específica del trabajo social no se define sólo por ello, sino por el modo en que juegan los saberes, las prácticas y técnicas de la disciplina en una red social específica o en la trama de las diferentes redes existentes y sus conflictos.

Llegar a la toma implicó un largo camino previo donde se fueron generando las posibilidades para que eso finalmente ocurriera y la manera de poder visualizarlo y analizarlo fue a partir de la Etnografía. En efecto, la Etnografía como forma de conocimiento me permitió investigar la toma desde mi lugar profesional allí, superando la idea de separación entre intervención disciplinar e investigación académica. En este proceso, la escritura del cuaderno de campo me permitió reflexionar diariamente sobre mi trabajo, las intervenciones, las políticas sociales, las percepciones que trasmitían las personas en relación a ello. Esto me llevó a cuestionar aspectos y a distinguir potencialidades de mi trabajo y a realizar un ejercicio de documentarlo con el material obtenido en el campo (copias de actas acuerdo, planos, fotos, etc.).

En este camino fui dialogando (y debatiendo) con las producciones disciplinares de las diferentes perspectivas y con el corpus teórico de las Ciencias Sociales. El trabajo etnográfico me permitió describir y analizar mis intervenciones profesionales cotidianas en diferentes ámbitos con la libertad de reflexionar a partir de los hallazgos en el campo. La Etnografía me permitió integrar diversas perspectivas sobre el desarrollo de la toma, las distintas experiencias, recursos, deseos y expectativas invertidas por los participantes y desde allí interrogar mis propias intervenciones como trabajador social de un municipio del Gran Buenos Aires. En el mismo camino que inicié en la carrera de grado el cuaderno de campo constituyó el medio para poder realizar esto y entender qué significaba estar en la toma. 
Estar en la toma, fue la cristalización de mi labor en Florencio Varela donde mi lugar profesional se fue construyendo en la intervención y escucha de esos miles de personas con sus historias singulares y cotidianas que se acercaban a pedir ayuda, asesoramiento o expresar la desesperación por sus condiciones de vida. Aquí se fue forjando el trabajo con las redes formales e informales de organizaciones, personas e instituciones, a lo largo de esos años y donde a la vez, fui incluido en sus redes y estrategias que agenciaban mi saber profesional. Esa construcción no hubiese sido posible sin el reconocimiento barrial por el trabajo asistencial (ese que tanto me cansaba y generaba contradicciones) gracias a lo cual aprendí que hablar como los piqueteros no se traducía en ser comprometido y además permitía que se me cuestionara el saber profesional. El trabajo asistencial en un contexto de pobreza estructural y políticas sociales focalizadas representó contradicciones y tensiones, aunque siempre busqué la manera de por un lado superar la focalización de esas políticas a través de diferentes estrategias profesionales y por otro lado, utilizar ese reconocimiento para potenciar lo promocional y preventivo a través de la Red Contra la Violencia. Puedo afirmar entonces que el dilema entre asistencia (asistencialismo, como se lo califica despectivamente) y realizar prácticas transformadoras y/o reivindicativas fue un falso dilema. Entre ambas existió una circularidad, si la asistencia me permitía llegar a lo reivindicativo, en las prácticas reivindicativas aparecía la posibilidad de disputar recursos al Estado municipal para situaciones donde antes estaban vedados. Asimismo, podía continuar con las prácticas reivindicativas, transformadoras, por el amparo que me daba lo asistencial, esto me lo recordaron los referentes del PJ del barrio La Esmeralda al reclamarme que no me olvide del trabajo asistencial en ese barrio. En este sentido, también es cierto que pude continuar porque en gran medida mi trabajo y los saberes profesionales en sus múltiples dimensiones, eran un recurso agenciado por el propio Estado Municipal para tratar con aquellos que demandaban su asistencia. Más allá de mis intenciones y de los reproches que solían hacer mis jefas, "los sociales" éramos funcionales en muchos aspectos, entre ellos, una válvula de escape cuando las tensiones se acumulaban o poseedores de un conocimiento acreditado a la hora de producir información que permitiera censar y seleccionar a la población. Describí y analicé numerosas situaciones en las cuales fui impulsado a negociar los diferentes usos del trabajo social en este complejo entramado socio-territorial.

En tanto, la constitución de la Red Contra la Violencia también fue posible por las herramientas adquiridas en mi formación de grado, donde el fortalecimiento de la Atención Primaria de la Salud (en contraposición al modelo médico hegemónico y a las concepciones hospitalocéntricas), la capacidad para trabajar interdisciplinariamente e intersectorialmente y en equipo conociendo las dinámicas institucionales, fueron pilares de mi educación como 
aspirante a la profesión. La Red Contra la Violencia, al irme en noviembre del 2014 había cumplido nueve años y cientos de reuniones y actividades realizadas sin incluir la articulación por situaciones que compartíamos. Uno de los logros más importantes fue invitar a las organizaciones sociales a participar de ella de esta forma trascendiendo los ámbitos institucionales.

El trabajo preventivo y promocional con La Red me permitió aunar la coordinación con las organizaciones del Encuentro Territorial, en un equipo de trabajo que incluyó a la residencia PRIM y al EFAPS. La potencialidad de las colegas residentes y de las diferentes disciplinas favoreció esta articulación y permitió multiplicar los análisis, proyectos y estrategias en torno al nuevo asentamiento. La decisión en conjunto con la residencia de darle prioridad al nuevo asentamiento fue un posicionamiento político, profesional y sanitario y parte de las disputas con los mandatos que me implicaba estar trabajando para el Estado Municipal.

La habilitación/invitación de los referentes fue la puerta de entrada a mi participación en la toma lo que no significaría que eso solo alcanzara para sostener mi presencia allí y en el transcurso del proceso fui aprendiendo como seguir estando allí. Conviviendo con tensiones, contradicciones y por momentos con la desorientación típica de un trabajador social empleado por el municipio. Esto lo pude ir resolviendo por el apoyo de este equipo y básicamente porque desde el Encuentro Territorial y los delegados y muchas de las personas del barrio, mi lugar (y límites laborales) estaba claro y lo íbamos construyendo juntos a medida que sucedían los acontecimientos.

Estar en la toma me permitió conocer el proceso de lucha de las clases populares sobre el acceso al hábitat, donde la primera toma se dio sin la organización previa que era necesaria para lo que se avecinaba. En efecto, no se pareció a las descripciones que había leído en la literatura: no habían armado grupos de trabajo, ni siquiera tenían planos de los terrenos con los lotes asignados (el campamento indio es una muestra de ello), tampoco contaban con la ayuda de referentes de otras tomas u organizaciones sociales, políticas ni eclesiales. Pero sí, en el pedido de los terrenos como mercadería, agua, los ocupantes apelaban a nociones legitimadoras de demandas (Thompson, 1995) y se valían de intervenciones históricas del Estado en lo referente a la posibilidad de obtenerlas. Aprendí que las luchas de las clases populares pueden guiarse por ciertas condiciones de posibilidad (el contexto de otras tomas en ese momento, los terrenos a ocupar, las personas que necesitan) cierta experiencia (básicamente la de Emilio y Leonor) y por la certeza de que antes de llegar a tomar intentaron, generalmente, múltiples estrategias. No quiero decir que la toma es la última y desesperada de esas estrategias, sólo quiero enfatizar que la perspectiva de E.P. Thompson adquirió para mí un valor considerable a la hora de 
analizar las respuestas de las clases populares frente a sus necesidades. Aquí también la Etnografía me permitió reconstruir esos procesos.

Las intervenciones de las agencias del Estado sobre la problemática del acceso a la tierra distaron mucho de garantizar derechos y se parecieron más a un juego de desgaste contra un adversario que se componía de hombres, mujeres y niños, todos pobres y donde se ponía en juego la variable de la salud. Porque las dilaciones, la falta de respuestas y los intentos de fragmentar la organización en esos meses, se tradujeron en el deterioro de la salud de esas personas.

En tanto, que no se haya desalojado, ni cuestionado, al horticultor ni al dueño del club sobre la toma de los terrenos (luego de que los integrantes del asentamiento limpiaran la totalidad de los mismos) es una vieja práctica según denuncia Robles (2011) donde se favorece a los medianos y grandes propietarios por parte del municipio en detrimento de las clases populares. Esto marca los acuerdos e intereses con los medianos propietarios y los referentes del PJ complementado por la presencia de la policía hostigando a los ocupantes, más allá del consejo inicial del comisario de que se "corrieran" a la vereda. En coincidencia con la literatura es algo que ha sido descripto desde los primeros asentamientos aunque en el contexto de la dictadura (Fara, 1985; Vommaro y Cravino, 2018). En este caso, además de la práctica de amedrentar y hostigar, garantizaron que el asentamiento no se ampliara hacia los terrenos usurpados por el club y el horticultor.

En tanto, ante la complejidad de este panorama, el Encuentro Territorial buscó sumar sus aliados para el plan de acción que había diseñado y separar a las personas que habían apostado por la alianza con el municipio y sus operadores. Esto le costó la permanencia allí a Emilio quien en este tiempo había desplegado todas las herramientas aprendidas en su recorrido de militancia social en pos de garantizar la viabilidad de la toma desde la organización inicial, coordinando con Ariel, hasta enfrentarse con el comisario y negociar con Mendoza, cuya afinidad con él por la pertenencia barrial se oponía con la de Robles, alguien del “centro". La combinación de las medidas de acción directa, de fuerza y la negociación con funcionarios de primer nivel del municipio y operadores territoriales a quienes ya conocía, tuvo un éxito inicial, pero en contrapartida fue aislándolo de otros referentes de la toma como Ariel, enfrentándolo con Robles y el Encuentro Territorial. Los acuerdos y negociaciones con Mereles, Mendoza y los funcionarios municipales era una apuesta destinada a fracasar, dado que ninguno estaba interesado en resolver la toma a partir de otorgar esos terrenos u otros. Emilio, agotada esta coordinación, quiso organizar una nueva toma, pero ya era tarde.

Entre esos aliados para la nueva toma el Encuentro Territorial me convocó considerando el 
compromiso con las familias del asentamiento y la buena disposición para conseguir los datos con los que Robles legitimaría públicamente la denuncia a las deficiencias de la política municipal y el reclamo por tierras. Así pude saldar ese momento incómodo donde mi voluntarismo, de moral sacrificial (Cazzaniga, 2016) atentó contra mi rigurosidad profesional, entre mi preocupación y mi necesidad de acompañar el proceso. Ese entusiasmo había complicado mi lugar en el asentamiento, hasta casi no poder sostener el vínculo con las familias que permanecían en "el campamento indio" poniendo en crisis mi rol profesional y mi posibilidad de acceder al campo. En vísperas de la nueva toma el Encuentro Territorial me habilitó nuevamente a entrar, fortaleciendo así la red de reciprocidad que Tania y Mary habían ido tejiendo en ese tiempo buscando viabilizar el plan que habían diseñado para los nuevos asentamientos. Así me constituí finalmente como un trabajador social en la toma y pude participar de la segunda toma. Ésta, organizada desde el Encuentro Territorial, marcó en primer lugar el crecimiento de este espacio durante ese año, donde se canalizó el aprendizaje de años de acompañamiento a otras tomas por parte del Centro Mugica y el empuje de los curas y Tania, en el contexto de la tradición del obispado de Quilmes. Fue la primera vez que organizaron una ocupación de tierras en conjunto y las dos nuevas tomas que resultaron en este proceso contemplaron la organización previa, el conocimiento de los terrenos, los delegados por manzana, el apoyo y participación de organizaciones e incluso el acuerdo con el comisario de la zona para que "llegara tarde".

La legitimidad y posibilidad de hacer las tomas, para el Encuentro Territorial, se midió por las negociaciones truncadas con el municipio, los meses de espera y el desgaste de las personas que ocupaban los primeros terrenos. Por lo que analicé a lo largo del proceso, en Florencio Varela liderar tomas de tierras y organizar barrios o impedirlo, es un capital político muy valioso en juego, lo que se confirma en la persistencia de los actores sociales que disputaron esta puja política. La ocupación de los nuevos terrenos fue una audaz decisión política que barajó el Encuentro Territorial, tomando terrenos de una banda mixta (policías y delincuentes comunes) vinculada a la venta de drogas, lo que constituye un aspecto novedoso al igual que el acuerdo con el comisario. El objetivo de tomar los terrenos fue que el municipio no pudiera defender al supuesto dueño de esas tierras (objetivo que fue alcanzado con éxito), pero a su vez incitó a la denuncia de éste contra los clareteanos frente al obispado (de lo cual derivó el apriete del obispo). El resultante fue el inicio de la ruptura dentro del espacio. Las diferencias sobre qué hacer ante esto dividió a las organizaciones, si para Robles se debía resolver en el ámbito público exponiendo al obispo para los clareteanos la lucha se daba en el interior de la estructura eclesiástica, ante la amenaza cierta de que se anulen proyectos vitales para ellos y además, con 
el riesgo de ser expulsados de la diócesis Esta última estrategia fue la que primó e implicó un reordenamiento de qué podían hacer y con quién abriendo un conflicto con el Centro Mugica que se fue acentuando en los años siguientes hasta la ruptura total de la alianza. Esta alianza tuvo la característica de ser temporaria por un lado pero por otro lado por la capacidad y el compromiso (aún con sus diferencias) lograron que los nuevos asentamientos se consolidaran como barrios.

Mi ingreso al campo fue a partir de la red informal de trabajo que agenció mi saber profesional en el proceso de la primera toma y mi salida del campo se produce con la conformación de estos dos nuevos barrios. Aquí culmina el proceso de investigación dado que su configuración como barrios marcan el fin de la etapa de la toma y se inicia una nueva etapa signada por lograr los servicios básicos y sostener la convivencia entre las familias. Asimismo, mi lugar como Trabajador Social se modificó en pos de lograr estos objetivos, armando una agenda en común con las organizaciones, explicitando mi intervención en los barrios ante la Municipalidad como parte de mi trabajo. Finalmente, el terreno oficioso en el que me moví todos esos meses dedicados a vincularme con las tomas se convirtió para mí y la residencia PRIM en lo oficial siendo el fortalecimiento a los dos nuevos barrios el hilo conductor de esa nueva agenda de trabajo. 


\section{BIBLIOGRAFÍA}

- Aquín, N. Custo, E. Torres, E. 2012. El problema de la autonomía en el trabajo social. En Revista de Trabajo Social, Plaza pública. Año $5-\mathrm{N}^{\circ}$ 7, Pág. 304 a la 320.

- Aquín, N. 2013. Intervención social, distribución y reconocimiento en el postneoliberalismo. En Revista Debate Público, Reflexión de Trabajo Social. Año 3 Nro 5, Pág. 66 a la 76.

- Aramburu, F.; Chiara, C. 2016. Los planes federales de vivienda en el área metropolitana de Buenos Aires. IX Jornadas de Sociología de la UNLP, 5 al 7 de diciembre de 2016, Ensenada, Argentina. En Memoria Académica. Disponible http://www.memoria.fahce.unlp.edu.ar/trab_eventos/ev.9056/ev.9056.pdf

- Aretse, M. 2011. Las acciones colectivas de protesta y el conflicto social en la Argentina de 1990: Apuntes sobre sus caracterizaciones. Sociohistórica (28), 107-129. En Memoria Académica. Disponible en: http://www.memoria.fahce.unlp.edu.ar/art_revistas/pr.5170/pr.5170.pdf

- Atencio V. et al. 2008. Políticas sociales municipales y organización gremial: Una experiencia del Trabajo Social en el distrito de Florencio Varela. Segundo foro latinoamericano de trabajo social. La Plata.

- Auyero, Javier. 2001. La política de los pobres. Las prácticas clientelares del peronismo. Buenos Aires, Editorial Manantial.

- Bayón M. y Saraví G. 2006. De la acumulación de desventajas a la fractura social. Nueva pobreza estructural en Buenos Aires. Cap 2. año 2006 en Saraví Gonzalo (editor) "De la pobreza a la exclusión. Continuidades y rupturas de la cuestión social en America Latina”. Editorial Prometeo libros.

- Bidaseca, K. 2004. Vivir bajo dos pieles: En torno a la resignificación de las políticas sociales y las complejidades del vínculo con el estado. El Movimiento de Trabajadores de Solano". Informe final, CLASPO-IDES. 
- Borgianni E. y Montaño, C. y Guerra, Y. (orgs.) (2003). Servicio Social Crítico. Hacia la construcción del nuevo proyecto ético-político profesional. San Paulo, Editorial Cortez.

- Campana, M. Asistencia social y restauración neoliberal. Conferencia presentada en el Panel de Apertura del Encuentro de la Regional Pampeana de la Federación Argentina de Unidades Académicas de Trabajo Social (FAUATS), Mar Del Plata, noviembre de 2016.

- Campana, M. Servio M. Hacia un sistema público estatal de asistencia social. Ponencia presentada en las “III Jornadas de Investigación de la Facultad de Trabajo Social”. Paraná, Entre Ríos. Año 2018.

- Campana, M. Servio M. La Asistencia Social como derecho. Protección, seguridad, asistencia y servicios sociales: apuntes para el debate. Ponencia presentada en IV Jornadas de Jóvenes Investigadores/as en Derecho y Ciencias Sociales . 17 al 19 de septiembre de 2014.

- Cassano, D. y Krakowiak, F. 2000. La construcción de la memoria municipal y la innovación en la gestión de gobierno. En: CRAVACUORE, D. y BADÍA, G. (comp.) Experiencias Positivas en Gestión Local, UNQ - UNGS - IDI, Bernal (Argentina).

-Catenazzi, A. 2009. Universalidad de las redes de agua y fragmentación en el conurbano bonaerense. Una lectura bajo el prisma de la consesión. En Catenazzi. El retorno de lo político a la cuestión urbana. Buenos Aires. ProUNGS,

-Cazzaniga, S. La ética socia como tema y como cuestión. A propósito de trabajo social. En VI Congreso red española de políticas sociales, "PACTAR EL FUTURO. Debate para un nuevo consenso en torno al bienestar”. Sevilla, 16 y 17 de febrero de 2016

-Carrera y Cotarelo. 2003. Argentina, diciembre de 2001: hito en el proceso de luchas populares. http://bibliotecavirtual.clacso.org.ar/clacso/formacionvirtual/20100724070658/13inigo.pdf

- CELS (Centro de Estudios Legales y Sociales). "Derechos Humanos en la Argentina”. Año 2016. 
- Colectivo Situaciones 4 .2001. Movimiento de Trabajadores Desocupados de Solano. Bs As, Ed. De Mano en Mano.

- Cravino, C. 2001. La propiedad de la tierra como un proceso. Estudio comparativo de casos en ocupaciones de tierras en el Área Metropolitana de Buenos Aires. En Land tenure issues in Latin America SLAS 2001, Conference Birmingham, April 6-8.

- Cravino, C. 2008. Los mil barrios informales en el AMBA. UNGS. Los Polvorines. 18 La Plata, 5 al 7 de diciembre de 2012 sitio web: http://jornadassociologia.fahce.unlp.edu.ar - ISSN 22508465

- Danani, C. 2006. Politización: ¿autonomía para el Trabajo Social? Un intento de reconstruir el panorama latinoamericano. En Revista Katálisis v. 9 n. 2, UFSC Florianópolis.

- Darré, S. 2005. Madres inapropiadas, maternidades problemáticas. Disponible en línea http://agendadelasmujeres.com.ar/index2.php?id=3\&nota $=1121$

- De la Llosa V. et al. 2012. Análisis de Situación de Salud. Asentamiento en Florencio Varela. Programa de Residencias Integradas multidisciplinarias. Florencio Varela.

- Dulcich Piccolo, R. Disertación en el marco de la maestría de trabajo social de La Plata. Año 2017.

- Dulcich Piccolo, R. 2008. Tesis Doctoral: Servicio Social en tiempos de barbarie. Dilemas y desafíos del proyecto profesional crítico en América Latina. Universidade Federal do Rio de Janeiro Centro de Filosofia e Ciências Humanas Escola de Serviço Social.

- España, A. 2013. Informe final Cátedra de Trabajo Social V”. La Plata. UNLP. FTS.

- Fara, L. 1985. Luchas reivindicativas urbanas en un contexto autoritario. Los asentamientos de San Francisco Solano, en Jelin, E. (comp.). Los nuevos movimientos sociales. CEAL, Buenos Aires. 
- Ferraudi Curto, C. 2014. Las fronteras cambiantes entre lo político y lo social: aportes etnográficos al debate en torno de “el 2001” en Argentina. Disponible en linea http://sedici.unlp.edu.ar/handle/10915/43959

- Ferraudi Curto, M. C. 2014b. Ni punteros ni piqueteros. Urbanización y política en una villa del conurbano. Buenos Aires, Editorial Gorla.

- Frederic, S. 2009. Trabajo barrial, reconocimiento y desigualdad en Lomas de Zamora, 19902005. En Grimson, Ferraudi Curto y Segura (comps.) La vida política en los barrios populares de Buenos Aires. Buenos Aires, Editorial Prometeo.

- Guber R. 2004. El salvaje metropolitano. Reconstrucción del conocimiento social en el trabajo de campo. Buenos Aires, Editorial PAIDÓS.

-Harvey D. "Breve historia del Neoliberalismo". Disponible en: http://colegiodesociologosperu.org/nw/biblioteca/breve-historia-del-neoliberalismo-de-davidharvey1.pdf>

- 1997b. Urbanismo y desigualdad social. Madrid, Editorial Siglo XXI.

- Healy K. 2015. Trabajo social: perspectivas contemporáneas. Traducción: Pablo Manzano. Director de la colección: Jurjo Torres Santomé. Barcelona, Ediciones Morata.

- Heler, Mario. 2001. La toma de decisiones responsables en la práctica del trabajo social; la reflexión ética como recurso. En Revista Conciencia social. Nueva época. №1. Publicación de la escuela de trabajo social de la Universidad nacional de córdoba. Diciembre. pp. 29-35

- Hirch, Victor. Exposición en el Foro-Debate: Tierra, vivienda y habitat. Universidad de Quilmes. 28 de abril del 2011.

- Iamamoto M. 1992. Renovagüo e Conservadorismo no Servido Social: Ensaios Críticos. Sao Paulo, Cortez.

- Iamamoto, M. 1997. Servicio Social y división del trabajo. Un análisis crítico de sus Fundamentos”. San Paulo, Editorial Cortez. 
-Iamamoto, M. 2003. El debate contemporáneo del Servicio Social y la ética profesional. En Borgianni, Elizabeth; Guerra, Yolanda; Montaño, Carlos (organizadores) Servicio Social crítico. Hacia la construcción del nuevo proyecto ético - político profesional. San Pablo, Cortez Editora.

- Lefebvre, H. 1973. De lo rural a lo urbano. Antología preparada por Mario Gaviria. Barcelona, Ediciones Península.

- Lefebvre, H. 1976b.Espacio y Política. El Derecho a la Ciudad II, Barcelona, Ediciones Península.

- Lozano, L. 2016. ¿El Estado, garante de la desigualdad? Tomas de tierras y ejercicio profesional. En Revista Institucional Escenarios Nro. 23: Perspectivas teóricas metodológicas sobre las desigualdades en América Latina.

- Lozano, L. ¡Soy piquetero! Tomas de tierra, trama social y trayectorias de vida. IX Jornadas de investigación, docencia, extensión y ejercicio profesional: Transformaciones sociales, políticas públicas y conflictos emergentes en la sociedad argentina contemporánea. La Plata, octubre 2014.

- Lorente Molina, B. 2004. Género, ciencia y trabajo. Las profesiones feminizadas y las prácticas de cuidado y ayuda social. En Revista Scripta Ethnologica, año/vol. XXVI. Consejo Nacional de Investigaciones Científicas y Técnicas, Buenos Aires.

- Maiorana M. 2008. La construcción de Territorialidad y el conflicto irregular urbano. Tesis de maestría. La Plata. Facultad de Trabajo Social. UNLP.

-Mallardi M. 2011. La Entrevista en Trabajo Social. Aproximaciones a un objeto polilógico. Aportes táctico-operativos a los procesos de intervención del Trabajo Social. Tandil; p. 53 84. 
- Manzano V. 2010. El hacerse y (des) hacerse del movimiento. Sobre espacios etnográficos y espacios en movimiento en el Gran Buenos Aires. En Grimberg, M. Ernandez, M. y Manzano V. (editores): Etnografia de las tramas políticas colectivas: Estudios en Argentina y Brasil. Bs As. Editorial Antropofagia.

- Manzano, V. 2008. Del desocupado como actor colectivo a la trama política de la desocupación: antropología de campos de fuerzas sociales. En: María Cristina Cravino (comp.): Acción colectiva y movimientos sociales en el Área Metropolitana de Buenos Aires.

-Menéndez E. 1990. Morir de alcohol: saber y hegemonía médica. México. Alianza Editorial Mexicana.

- Merklen, D. 1997. Organización comunitaria y práctica política. Las ocupaciones de tierras en el conurbano de Buenos Aires. En: Nueva Sociedad No 149, mayo-junio. Venezuela.

- Merklen, D. 2005. Pobres ciudadanos. Las clases populares en la era democrática (Argentina, 1983-2003). Buenos Aires. Editorial Gorla.

- Minassian, C. Maldini V., Defant V. 2008. Análisis situacional del asentamiento. Centro de Salud La Esmeralda. Florencio Varela. Programa de Residencias Integradas Multidisciplinarias.

-Muñiz Terra

L. 2012.

Carreras y trayectorias laborales: una revisión crítica de las principales aproximaciones teóric o-metodológicas para su abordaje. En Revista latinoamericana de metodología de las ciencias sociales.

- Montaño, C. 1998. La naturaleza del Servicio Social. Un ensayo sobre su génesis, su especificidad, su reproducción. San Pablo. Cortez Editora.

- Montaño C. La relación teoría-práctica en el servicio social: desafios para la superación de la fragmentación positivista y post-moderna. Ponencia presentada en el XIX Seminario Latinoamericano de Escuelas de Trabajo Social. El Trabajo Social en la coyuntura 
latinoamericana: desafíos para su formación, articulación y acción profesional. Universidad Católica Santiago de Guayaquil. Guayaquil, Ecuador. 4-8 de octubre 2009.

- Morin, E. 1998. Epistemología de la complejidad. En Fried, D. (coompiladora) Nuevos paradigmas: Cultura y subjetividad. Buenos Aires: Paidós. Segunda reimpresión. 421-453.

-Muñoz, M. Crisis política y conflicto social en Argentina: Alcances y límites de un tipo de participación política no convencional. En Revista European Review of Latin American and Caribbean Studies 87, October 2009 | 63-92.

- Netto, J. P. 1997. Capitalismo monopolista y Servicio Social. San Paulo, Cortez, 1997.

- Netto, J. P. 1981b. La crítica conservadora a la reconceptualización”; in Rev. Serviço Social $\&$ Sociedade $n^{\circ}$ 5. San Paulo, Cortez.

- Netto, J. P. 1996. Transformações societárias e Serviço Social - notas para uma análise prospectiva da profissão no Brasil’. Rev. Serviço Social \& Sociedade n 50. Cortez; São Paulo.

- Oliva A. 2015. Trabajo social y lucha de clases: análisis histórico de las modalidades de intervención en Argentina. La Plata. Editorial Dynamis.

- Oldani T. 2016. Intentando pensar los procesos de Salud Colectiva Y Epidemiologia Critica, con un Movimientos Social del Conurbano. Análisis de situación de salud. Florencio Varela.

- Peirano, M. 1997. Antropologia política, ciencia política e antropologia da política. En Três ensaios breves. Série Antropologia 231, Brasilia: Universidad de Brasilia.

- Perelmiter L. 2010. El lugar del personal estatal en las teorías del Estado. Miliband y Poulantzas”. En “Intersicios” Revista Sociológica de pensamiento crítico.

- Petras J. Reforma o Revolución. Una discusión en las condiciones actuales de América Latina. Exposición en el Forum Social Mundial Porto Alegre 2002. Disponible en linea en https://www.nodo50.org/pretextos/petras6.htm 
- Pinedo J. 2018. Urdimbres y tramas. Transformaciones de la acción colectiva popular en el sur del Gran Buenos Aires (1974-1989). Tesis para Obtener el grado de Doctor en Ciencias Sociales. Universidad Nacional de General Sarmiento. IDES.

- Pontes, R. 2003. Mediación: categoría fundamental para el trabajo del asistente social. "n Elisabete Borgianni, Yolanda Guerra y Carlos Montaño (orgs.), Servicio social crítico - Hacia la construcción del nuevo proyecto ético-políticoprofesional, Sao Paulo, Brasil, Cortez Editora.

- Quirós J. 2006. Cruzando la Sarmiento. Una etnografía sobre piqueteros en la trama social del sur del Gran Buenos Aires. Buenos Aires: Centro de Antropología Social, Instituto de Desarrollo Económico y Social; Editorial Antropofagia.

- Quirós J. 2011b. El porqué de los que van. Peronistas y piqueteros en el Gran Buenos Aires (una antropología de la política vivida”. Buenos Aires. Editorial Antropofagia.

- Reese, E. Octubre 2014. La informalidad agrava la pobreza. Periódico Página 12.

-Retamozo, M. 2006. El Movimiento de Desocupados en Argentina: subjetividad y acción en la disputa por el orden social". Tesis presentada para obtener el título de Doctor en Investigación en Ciencias Sociales con especialización en Ciencia Política de la Facultad Latinoamericana de Ciencias Sociales-Sede Académica de México.

- Salomone, A. 2015. Un repaso de la política alimentaria argentina en los últimos 50 años. En Revista Argonautas. AÇo 5, NÉ 5: 1- 22

- Santillan y Woods. 2005. Iglesia y cuestión social: la intervención de la Iglesia Católica en la construcción de demandas de educación, tierra y vivienda en el Gran Buenos Aires. En Revista de antropología, disponible en $\quad$ sitio web http://www.scielo.br/scielo.php?script=sci_arttext\&pid=S0034-77012005000100007

- Sigal, S. 1981. Marginalidad espacial, Estado y ciudadanía. En Revista Mexicana de Sociología $\mathrm{N}^{\circ}$ 4/81, México. 
- Schuttenberg M. y Lozano J.I. 2017. Estado y movimientos sociales. Una propuesta para pensar la relación en torno a cuatro dimensiones de análisis. En: Camou, Antonio; Pagani, María Laura, coordinadores. Debates teóricos y metodológicos actuales sobre las políticas públicas. La Plata: UNLP. FAHCE. (Capítulo).

- Stratta y Barrera. 2009. El tizón encendido. Protesta social, conflicto y territorio en la Argentina de la posdictadura. Buenos Aires. Ed. El colectivo.

- Sosa M. y Álvarez R. 2010. Trabajo final del Posgrado en Salud social y comunitaria, programa Médicos Comunitarios. La Plata. UNLP. FCM.

- Stolkiner A. 1999. La Interdisciplina: entre la epistemología y las práctica. Disponible en línea http://www.campopsi.com.ar/lecturas/stolkiner.htm

- Svampa, M. 2005. Entre la ruta y el barrio. La experiencia de las organizaciones piqueteras .Buenos Aires. Editorial Biblos.

- Svampa, M. 2005. La nueva configuración social, en La sociedad excluyente. La Argentina bajo el signo del neoliberalismo, Buenos Aires: Ed. Taurus.

- Tenti Fanfani, E. 1989. Estado y pobreza: estrategias típicas de intervención. Centro Editor de América Latina. Biblioteca Política Argentina No 255. Buenos Aires.

- Thompson, E. 1995. Economía moral revisitada. En: Costumbres en común. Barcelona. Critica.

- Thwaites Rey, M. 1999. El Estado: nota(s) sobre sus significado (s). Publicación de la FAUD, Universidad Nacional de Mar del Plata.

- Tilly, Ch. 2000. Acción colectiva. Apuntes de Investigación del CECyP, No 6.

- Tufró, Brescia y Lefevre. 2016. Aguantamos contra el Estado, perdemos contras las bandas. Reflexiones sobre la circulación de violencias en tomas de tierra y asentamientos. Editorial: IIGG, Fsoc (UBA). Colección: Revista Quid. 
- Vidal, M. 2017. Movimientos Sociales, Trabajo Social y Disputas Territoriales, en el ciclo kirchnerista: El caso de tomas de tierras en Cipolletti, como síntesis de múltiples determinaciones. Tesis de Maestría. Facultad de Trabajo social. UNLP.

- Vommaro P. y Cravino C. 2018. Asentamientos en el sur de la periferia de Buenos Aires: orígenes, entramados organizativos y políticas de hábitat. En Población \& Sociedad [en línea],ISSN 1852-8562, Vol. 25 (2), 2018, pp. 1-27. DOI:http://dx.doi.org/10.19137/pys-2018250201. Puesto en línea en diciembre de 2018.

-Vommaro G. y Quirós J. 2011. Usted vino por su propia decisión: repensar el clientelismo en clave etnográfica. Revista Desacatos, número 36, mayo-agosto 2011, pp 65-84.

- Woods, M. 2003. Modalidades de intervención de la iglesia católica en conflictos sociales territoriales en torno al trabajo y la tierra. III Jornadas de Sociología de la UNLP, 10 al 12 de diciembre de 2003, La Plata, Argentina. En Memoria Académica. Disponible en: http://www.memoria.fahce.unlp.edu.ar/trab eventos/ev.7012/ev.7012.pdf

- Wacquant. 2007. Los condenados de la ciudad: guetos, periferias y Estado. Bs As. Siglo XXI.

- Wilner A. Stolkiner A. 2007. Abordajes de la Atención Primaria y el Derecho a la Salud en los países del Cono Sur - En Red ISSS" Algunas ideas sobre la Atención Primaria de la Salud en Argentina.

- Woods, M. 2003. Modalidades de intervención de la iglesia católica en conflictos sociales territoriales en torno al trabajo y la tierra. III Jornadas de Sociología de la UNLP, 10 al 12 de diciembre de 2003, La Plata, Argentina. En Memoria Académica. Pág. 18. Disponible en: http://www.memoria.fahce.unlp.edu.ar/trab_eventos/ev.7012/ev.7012.pdf

- Zibechi. E. 2003. Maxi y Darío: Dignidad Piquetera. En Boletín de La Brecha. 
ANEXOS

Barrios del área programática del Centro de Salud La Esmeralda.
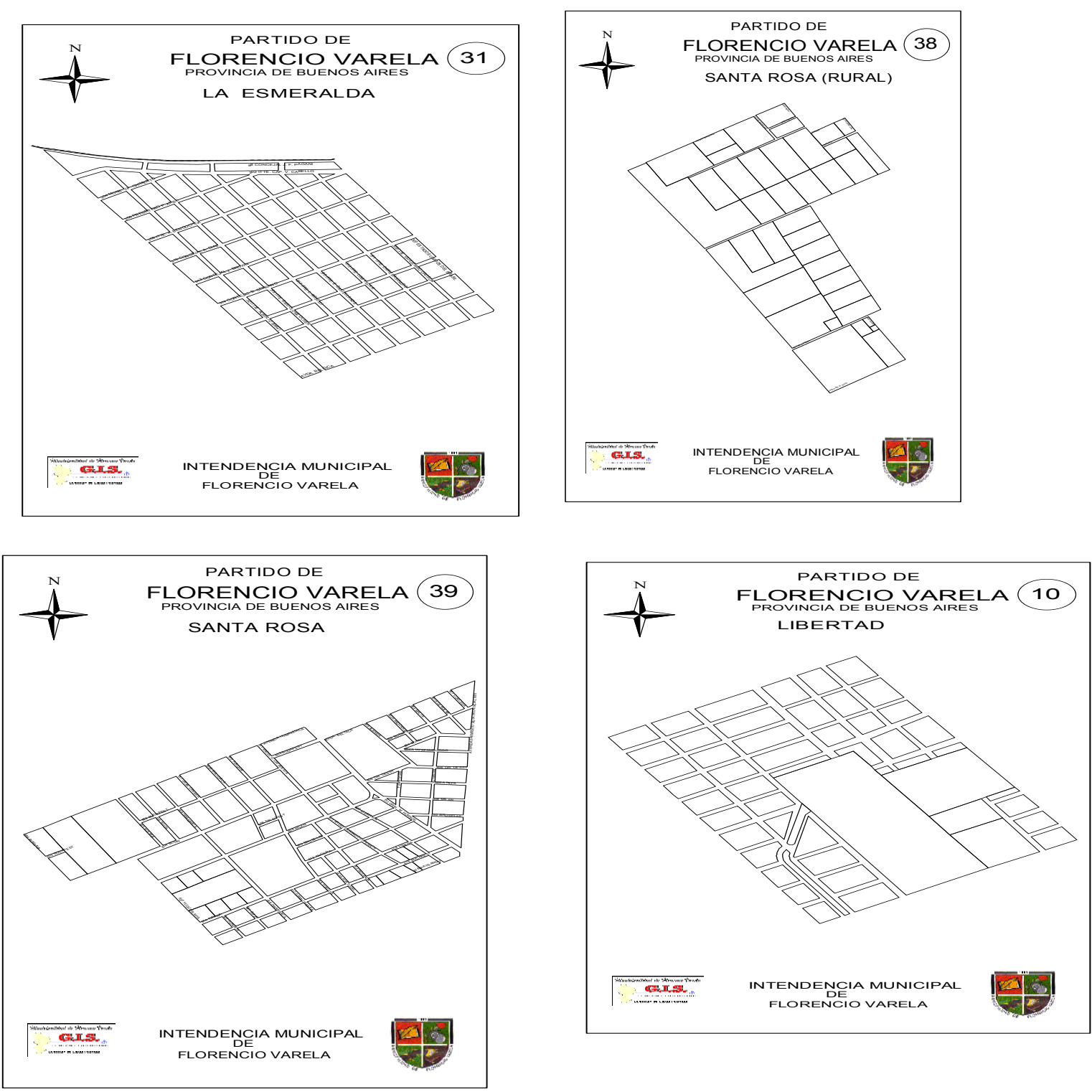

Dentro del barrio Libertad se encontraba el asentamiento 9 de mayo, en el barrio Santa Rosa se incluía el asentamiento 10 de febrero.

El asentamiento 7 de abril y La cañada se encontraban por fuera de los límites del área. 


\section{Gaĩag ERREDADAS}

Desde el año 2005 somos la escuela,

la salita, la iglesia, las organizaciones sociales...SOMOS EL BARRIO

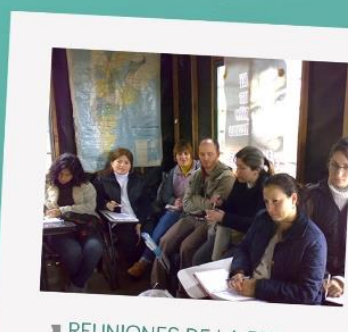

॥ REUNIONES DE LA RED
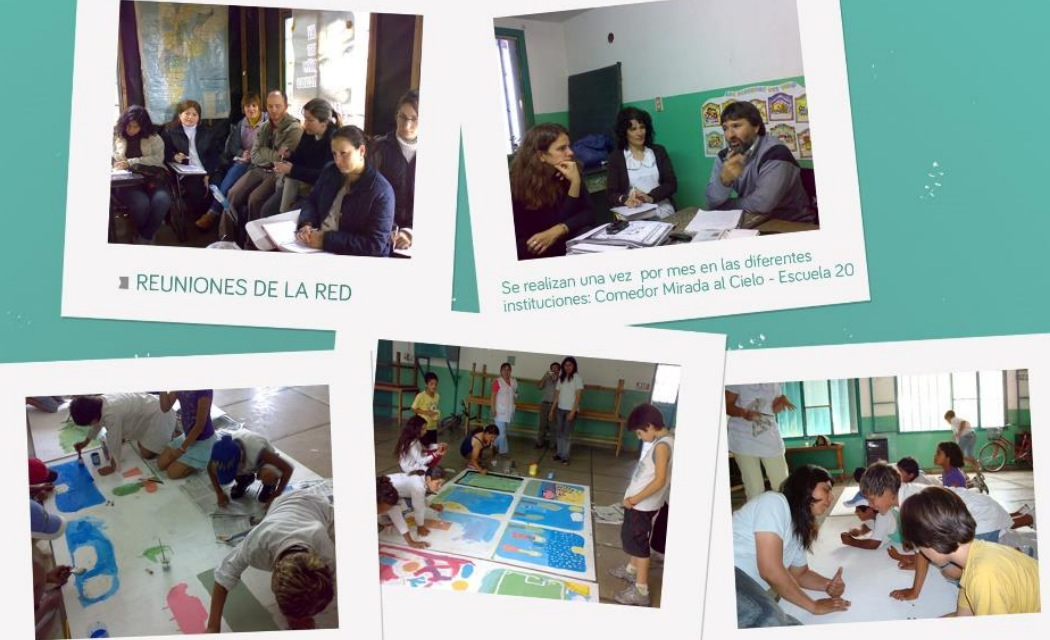

I. Mural realizado por alumnos sobre

los Derechos
Escuela 20
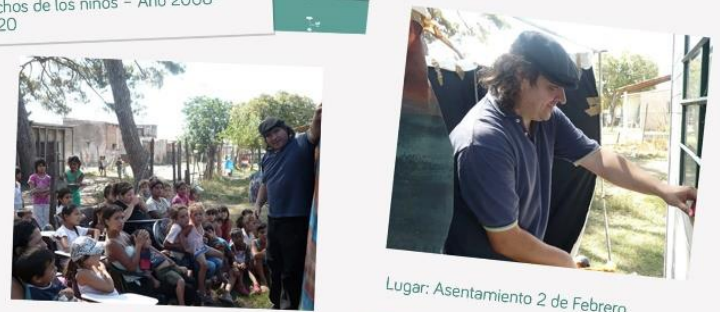

II Proyecto con Titeres- Derechos de
los niños - Año 2008 .
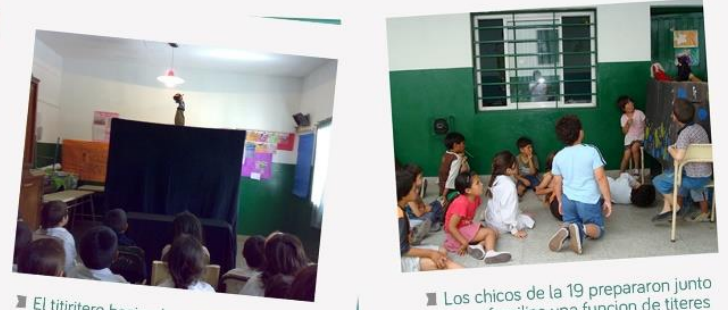

I Los chicos de la 19 prepararon junto

en la escuela 19 - Año funciones 
PRIMERA TOMA. En la vereda

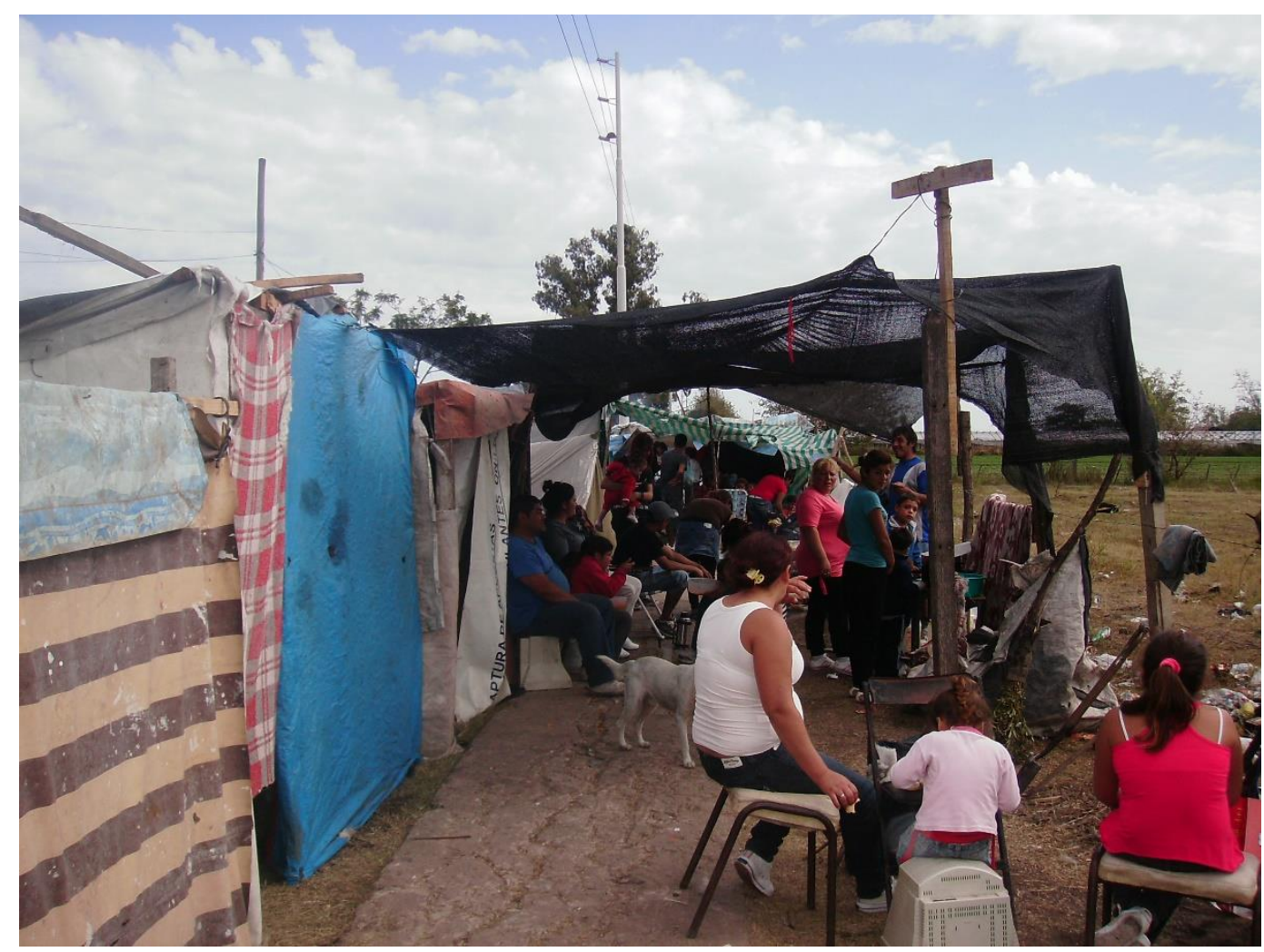

Fotos tomadas por Amelia García. 

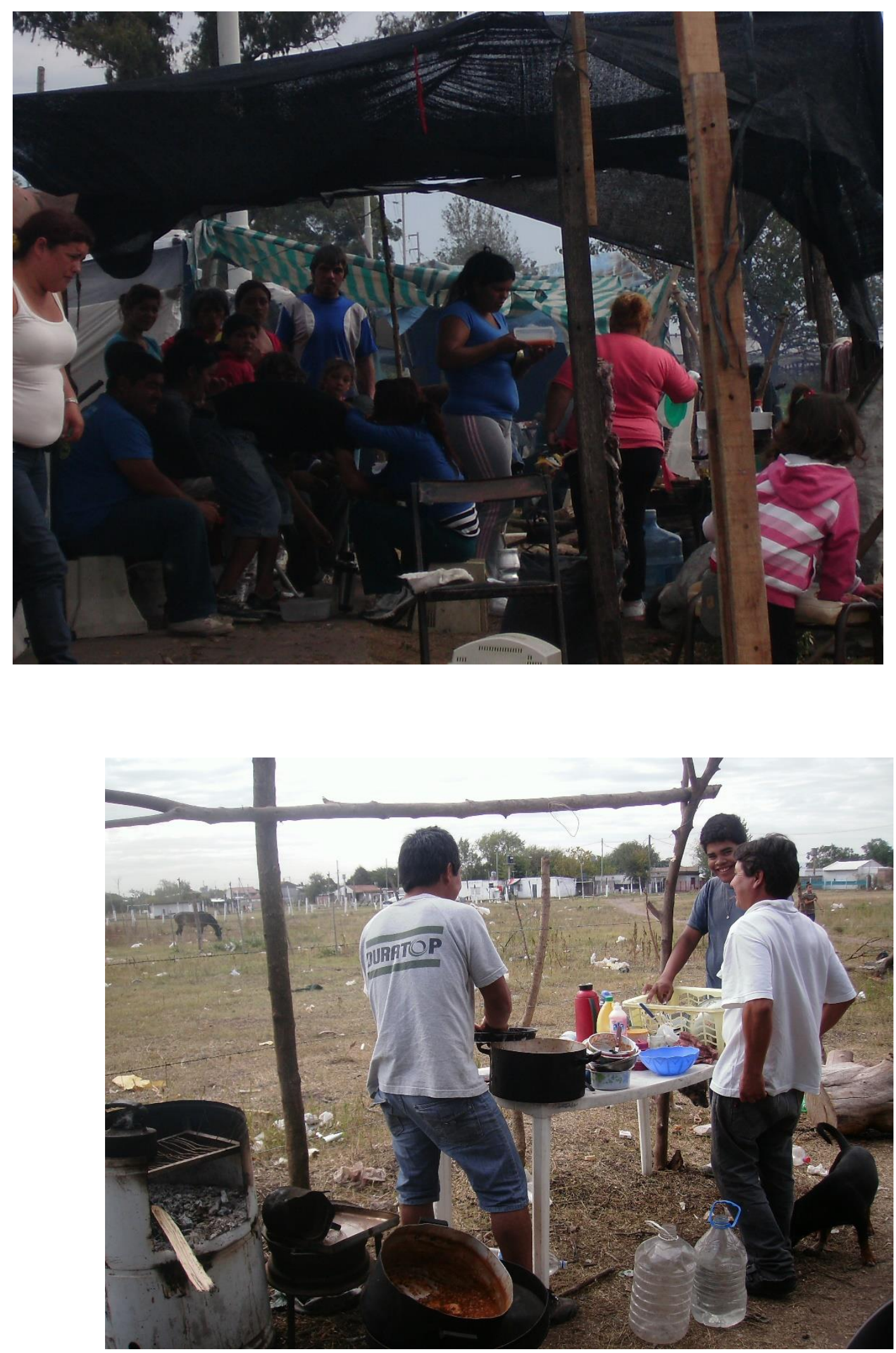


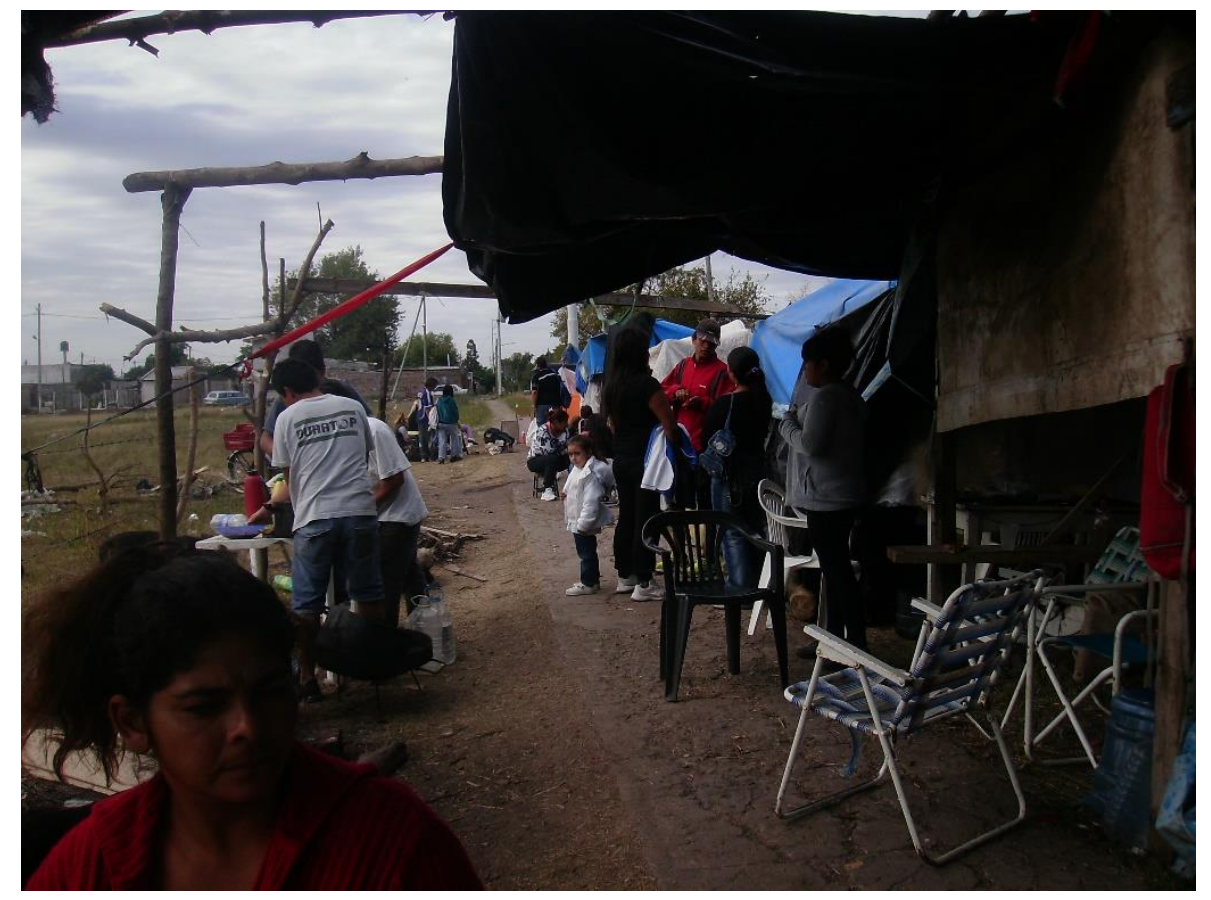

En la vereda, ya con el alambrado.

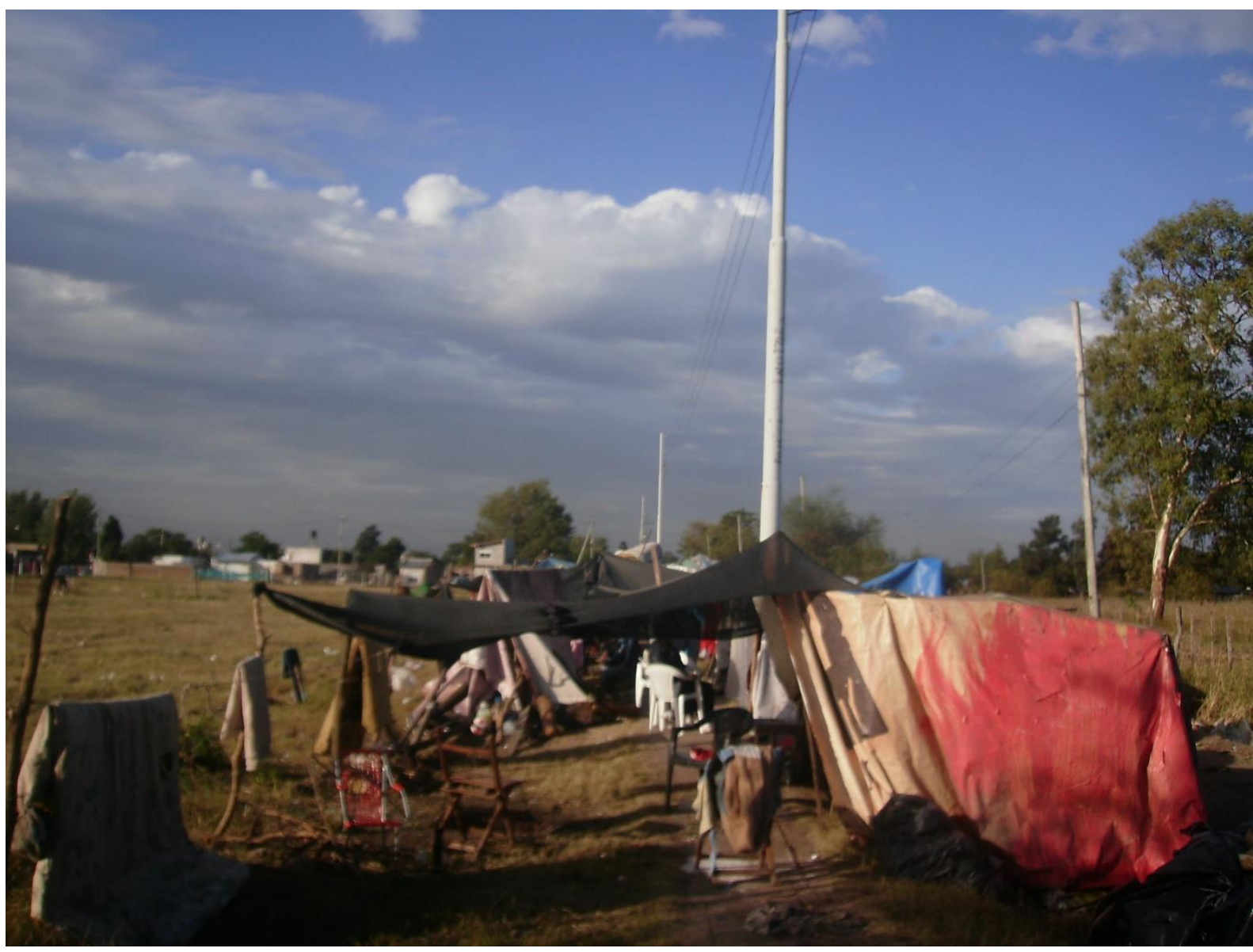




\section{Tierra de nadie}

Llegamos una madrugada a una tierra sin cuidado basurales y desperdicios encontramos.

Buscando un lugar donde vivir hasta aqui llegamos,

Nosotros divisamos un futuro limpio y sano para nuestras familias sabemos que podemos cambiarlo el futuro es un reto, pero somos fuertes necesitamos esta tierra para cumplir con nuestras metas.

No pedíamos más que tierra, día a día peleando por lo que nos corresponde todo ciudadano de este país tiene derecho a un pedazo de tierra suelo de nuestra patria que de ser necesario daríamos la vida por defenderla. No somos usurpadores ya que queremos pagar dennos la oportunidad de adquirirlo dignamente.

Gente en la calle espera bajo la lluvia, sol, frio y hasta con hambre por cuidar un lugar que creemos nuestro. Quizás sea un sueño, pero está en todos hacerlo realidad.

No bajaremos los brazos, todas las mañanas al ver las caritas de nuestros hijos los corazones se nos llenan de valor, fuerza y valentía para seguir luchando por el sueño de una casa propia.

\section{Artículo en el diario "El Quilmeño" sobre una jornada del "Encuentro Territorial" del 17/04/2011.}

"Se llevó adelante el Quinto Encuentro de Tierra, Vivienda y Hábitat organizado por el Encuentro Territorial" de Florencio Varela, y en el encuentro participaron más de cien delegados de asentamientos y complejos habitacionales. Dicho encuentro se realizó desde las 14, en la sede del Centro de Participación Popular Padre Carlos Mugica, ubicado en (...) Villa Argentina, donde se desplegó un fuerte trabajo en grupo que profundizó la relación con el gobierno local, la participación barrial y cómo mejorar la articulación entre los diferentes barrios. Después de más de tres horas de trabajo y con una fuerte presencia de mujeres, migrantes y jóvenes, se resolvió: "Solidaridad activa con los nuevos asentamientos de Santa Teresa y Villa Argentina; exigir el cumplimiento de la totalidad del acuerdo alcanzado entre los delegados del barrio Agustín Ramírez y las autoridades municipales; fortalecer la articulación quincenal entre los diferentes delegaciones de los barrios que luchan por la tierra la vivienda y el hábitat; difundir por diferentes medios de comunicación la emergencia habitacional que viven miles de familias en nuestro distrito; profundizar la participación de las comisiones de vecinos en los diferentes conflictos en la búsqueda de soluciones ante el estado; repudiar cualquier desalojo por medio de fuerzas de seguridad, ya que la solución es el cumplimiento de las obligaciones del estado en garantizar el acceso de los ciudadanos a la tierra, la vivienda y el hábitat". Además del trabajo en comisiones se desarrolló un plenario en donde se expusieron las diferentes conclusiones de los grupos, al terminar el mismo se cerró dicha actividad con una emotiva celebración ecuménica, en la cual se compartieron sueños, logros y aprendizajes de estos cinco años de lucha del Encuentro Territorial. Participaron del encuentro: Parroquia Santa Teresa, Parroquia San Cayetano, Departamento de Justicia y Paz (Obispado de Quilmes), Centro Padre Mugica, Delegados de loteo social de Ingeniero Allan, Delegados del loteo social El Rocío, Delegados Asentamiento Villa Brown, asentamiento 9 de febrero, asentamiento 9 de mayo, asociación civil el colectivo de La cañada Villa Argentina, asentamiento Villa Argentina Nueva, asentamiento Nuevo Santa Teresa, asentamiento Santa Teresa, centro comunitario Los Pitufos Santa Inés, Centro comunitario Los Duendecitos El Triángulo de Don José, centro comunitario Unión, Fuerza y Esperanza 3 de Mayo, comisión de Delegados San Cayetano". 
Carta al intendente realizada por las personas de la toma y el "Encuentro Territorial"

NOSOTROS TAMBIÉN TENEMOS DERECHOS...

Al Intendente de Fcio Varela

Sr Julio Pereyra

Somos un grupo de familias varelenses que hace cuatro meses estamos reclamando un lugar donde poder vivir, somos de los barrios de San Jorge y Villa Argentina. Los tres asentamientos nos fuimos organizando reclamamos nuestro derecho a una vivienda digna donde podamos vivir dignamente. Hemos recibido apoyo del Espacio de Tierras donde juntos nos sentamos en una mesa de dialogo con funcionarios de su gestión.

Como usted bien sabe, en nuestro querido distrito hay muchas familias que se encuentran en emergencia habitacional, nosotros somos parte de esa mitad de la población varelense que espera o lucha por tener una vivienda digna, muchos de nosotros vivía con familiares hacinados, otros hemos sido desalojados $y$ otros no podemos acceder a pagar un alquiler. $Y$ parafraseando a Aristóteles y a un líder que seguramente usted admira mucho dijeron que "La única verdad es LA REALIDAD" y nosotros hace cuatro meses seguimos esperando una promesa que nos realizaron: LOTEOS SOCIALES. La REALIDAD es que todavía seguimos esperando en medio del barro, con nuestros hijos enfermos, con casillas de lona, cartones y maderas, en medio del frio y la lluvia.

Hemos comenzado una mesa de dialogo con funcionaros municipales donde hay luces y sombras para evaluar este camino de búsqueda de respuestas. Es importante agradecer la disponibilidad de la Subsecretaria de Gobierno y la Directora de Tierras en atendernos en cada reunión, sin olvidar que es su responsabilidad de funcionarios públicos. Un gran ausente es el Secretario de Salud y Desarrollo Social en esta mesa de dialogo y en estos meses no apareció en ninguna instancia para constatar como vivíamos.

Esta REALIDAD ES LA UNICA VERDAD SOBRE NUESTRA ESPERA... SEGUIMOS ESPERANDO QUE NOS ADJUDIQUEN LOTES SOCIALES DE TIERRAS DONDE EL ESTADO MUNICIPAL ES PROPIETARIO. Si usted es creyente rece y pida al Dios que crea para que este invierno su gestión municipal no sea responsable por la ineficacia de una muerte que pudo ser evitada con respuestas a la altura de la REALIDAD. 


\section{LA SEGUNDA TOMA.}

Las carpas instaladas en los lotes, atrás el Plan Federal de viviendas.

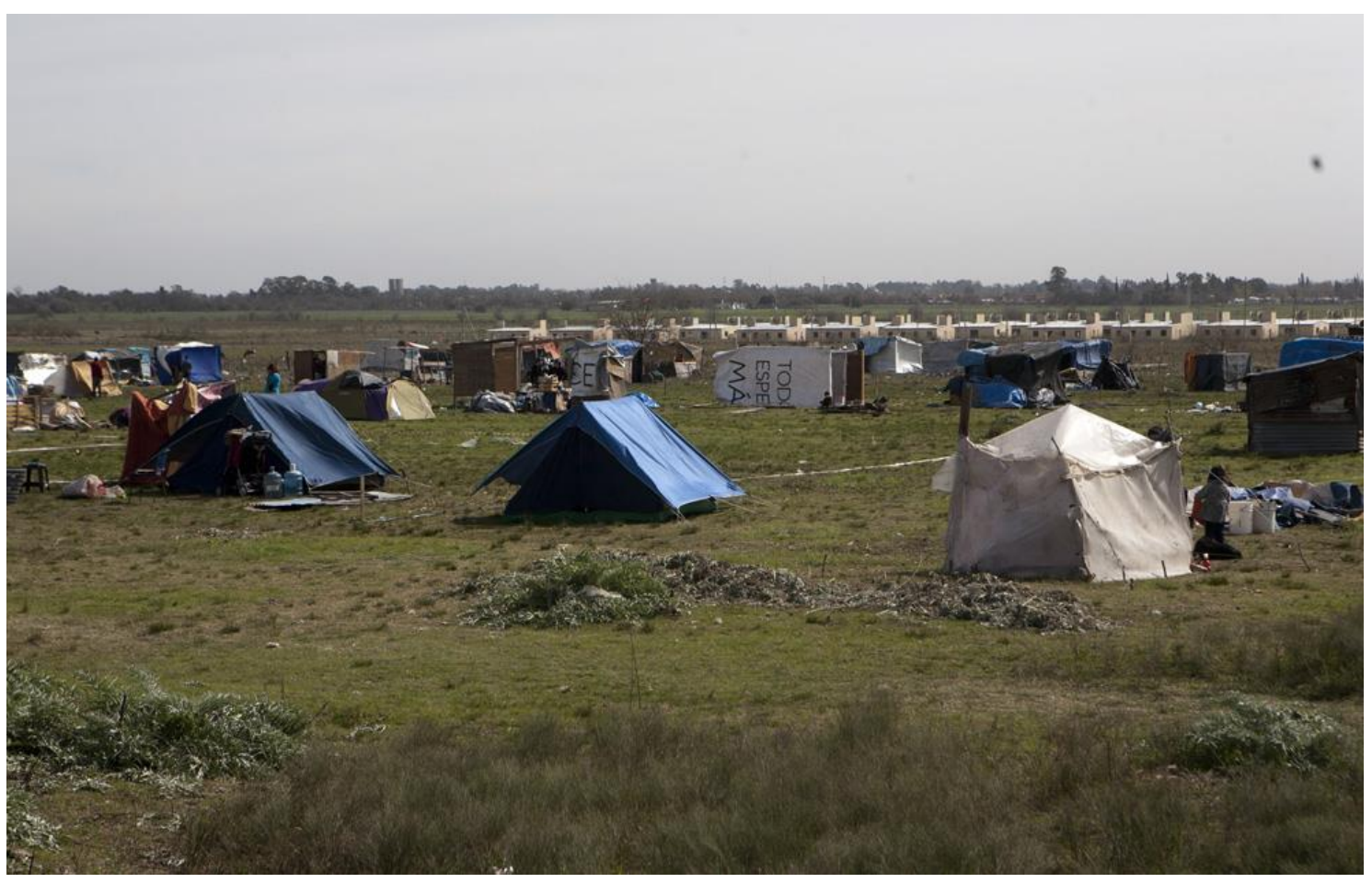

\section{La asamblea.}

Foto tomada por Amelia García.

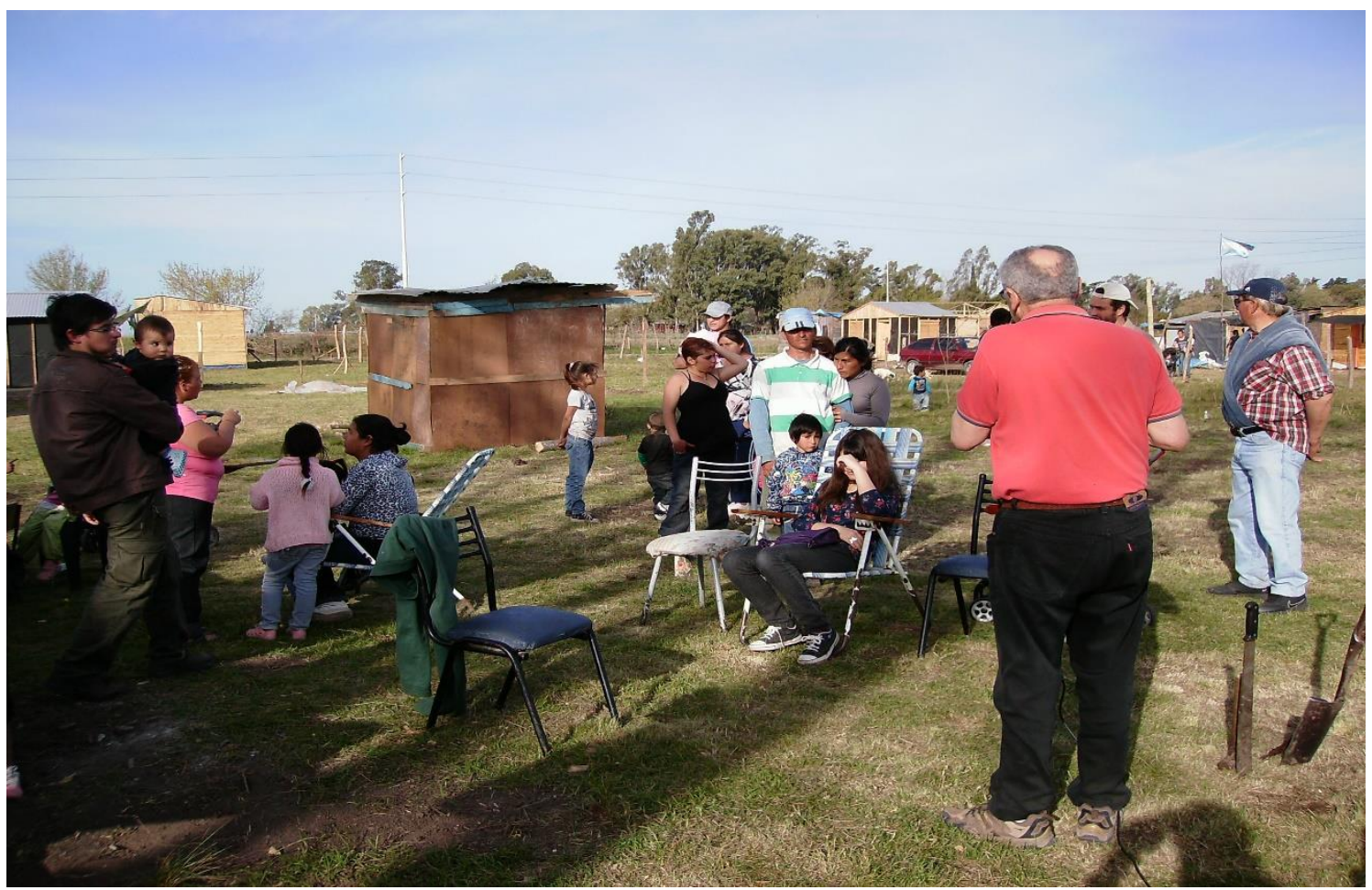


Las imágenes del gauchito Gil eran habituales en la toma y en Florencio Varela.

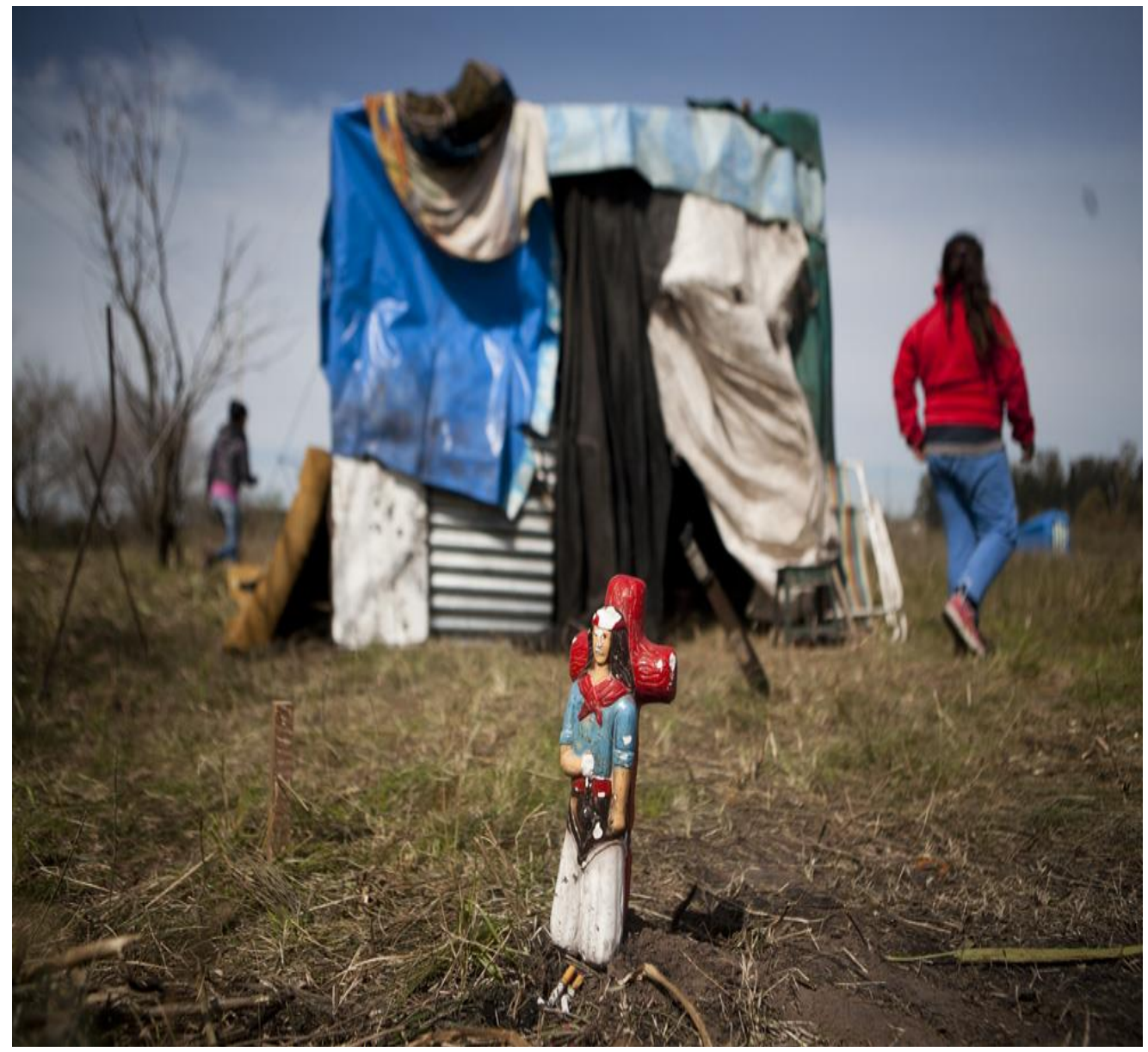

Foto tomada por Amelia García 


\section{ACUERDO PARA CONVIVIR EN EL BARRIO \\ BARRIO 7 de abril}

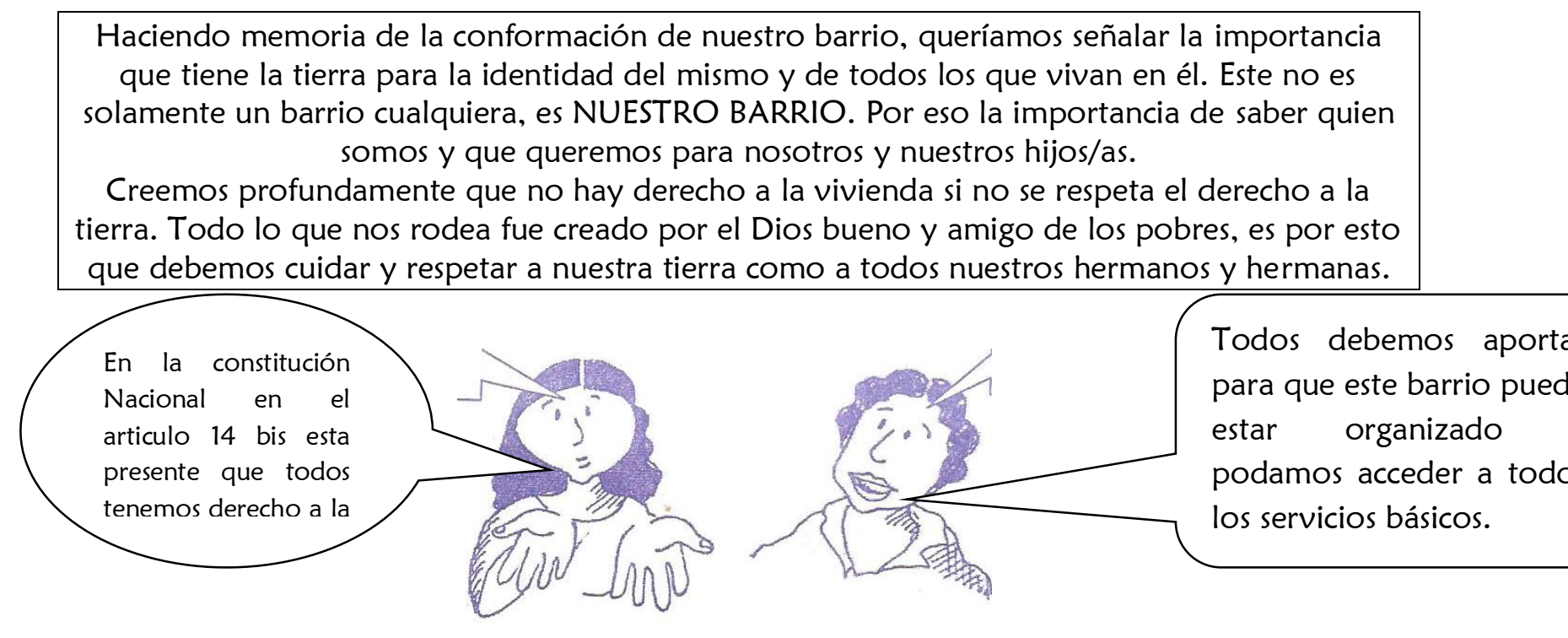

LOS ACUERDOS DEFINIDOS EN LA ASAMBLEA DEL 7 DE JULIO DE 2012.

Nosotros nos comprometemos a cumplir estos acuerdos definidos por todos los vecinos del barrio.

1. Las decisiones que tienen que ver con la organización del barrio se tomaran en asamblea donde tendrán que participar la mayoría de los vecinos/as. Alli se votaran las acciones a seguir por los delegados de manzana, como así también se resolverán los conflictos de convivencia, lo referido a los lotes y la urbanización del barrio.

2. Todas las familias que tienen un lote deben vivir en el barrio. Debe vivir una familia por lote.

3. Estas familias que tienen a cargo un lote, deben cuidar y limpiar su lote. Para su bienestar y para el buen convivir de sus vecinos y el barrio. Cuidando el barrio evitaremos enfermedades, como también ayudaremos a cuidar lo que es de todos.

4. Si alguna familia se fuera del lote o quisiera dejarlo momentáneamente, debe recurrir a sus delegados: avisar y acercarse en a la asamblea barrial para que los mismo decidan que hacer con ese lote.

5. Ninguna familia puede vender su lote hasta que cada uno sea dueño legalmente de su lote. Esto quiere decir hasta que cada vecino tenga en su propiedad LA ESCRITURA de su lote.

6. Frente a situaciones de inseguridad dentro del barrio como aledaño, los vecinos deben realizar la denuncia correspondiente. Pueden avisar a sus delegados y acercarse a la comisaría más cercana.

7. Todos tenemos derechos a festejar todos los acontecimientos de nuestra familia y el barrio, pero debemos organizarnos para no molestar innecesariamente a mis vecinos. Es por esto que durante los días de la semana podremos escuchar música fuerte hasta las 22:00hs. 
8. Sabemos que la droga esta perjudicando la vida de muchos chicos y chicas de nuestra sociedad. Por eso decidimos que nadie puede vender droga en nuestro barrio. Para el o la que lo realizara será denunciada.

9. También somos consientes que muchas mujeres están muriendo por causa de la violencia, es por esto que todo vecino o vecina que sea testigo de situaciones de maltrato a las mujeres del barrio deben realizar la denuncia correspondiente. Como también llamar al 911 si fuese necesario.

10. Los delegados serán elegidos en asamblea vecinal, y habrá por lo menos dos delegados por manzana. Sí alguno de ellos/as no quisiera seguir más con esta tarea deberá recurrir a la asamblea y notificar dicha decisión. El rol del delegado/a será: representar a sus vecinos animar la asamblea, participar de reuniones en el espacio de tierras, reunión de delegados y en el dialogo con el Estado.

En la lucha por la estatalización, aportes de la residencia PRIM

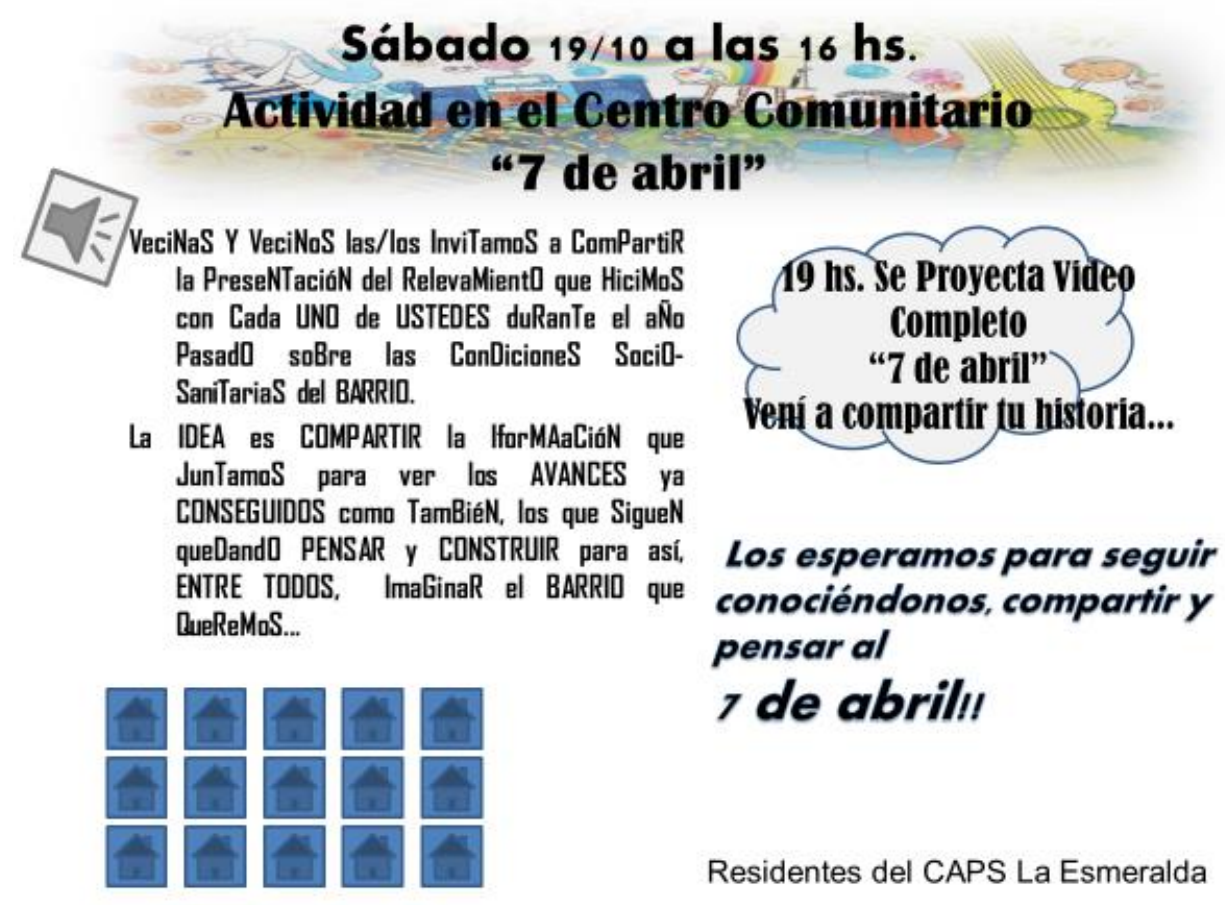

